U.S. Department of Energy

Assistant Secretary for

Nuclear Energy

Deputy Assistant Secretary for Nuclear

Reactor Programs

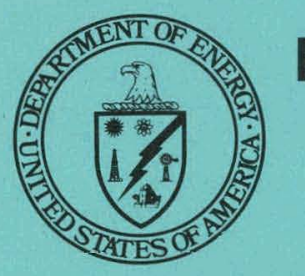

\title{
Program Summary for the Civilian Reactor Development Program
}

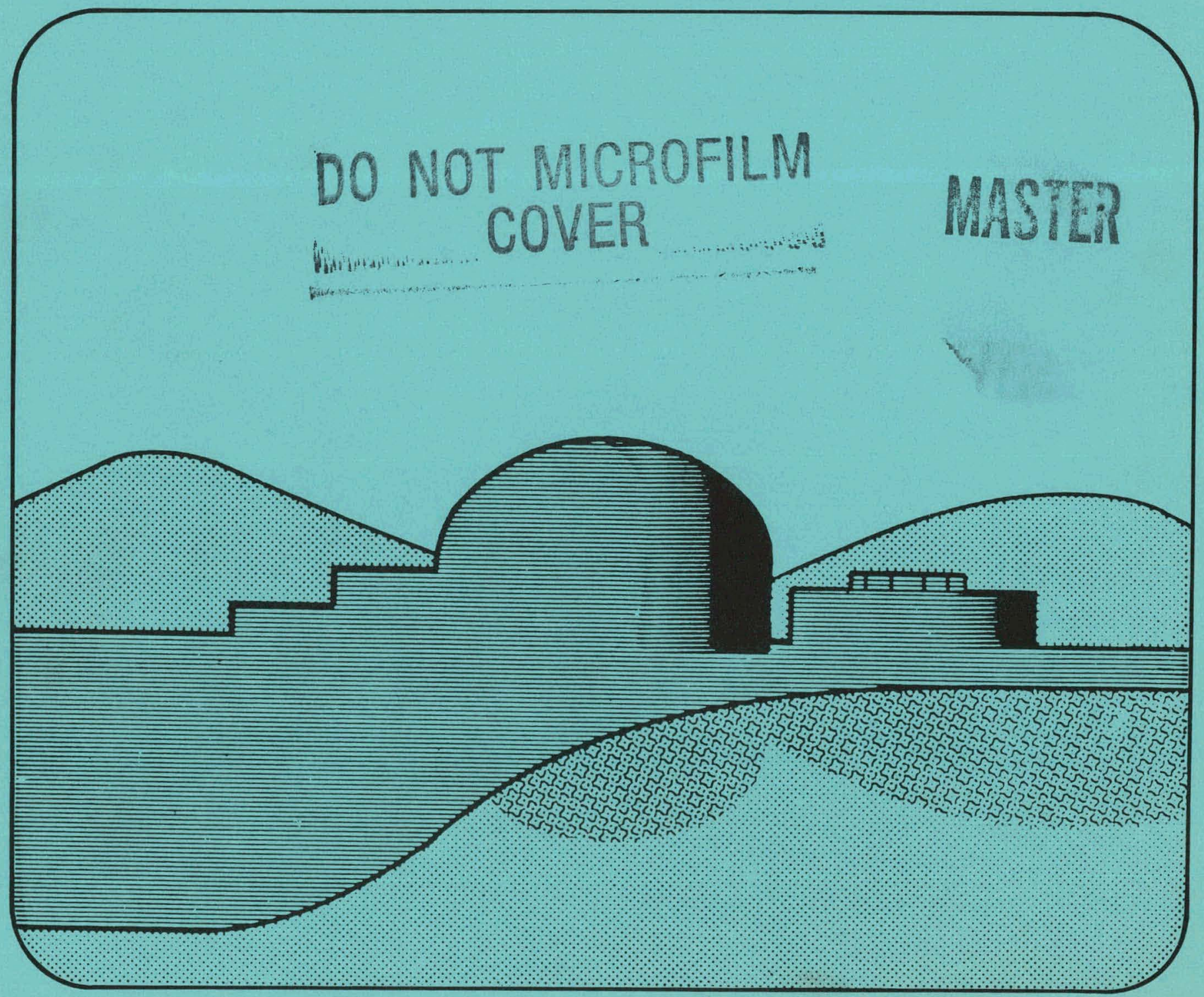




\section{DISCLAIMER}

This report was prepared as an account of work sponsored by an agency of the United States Government. Neither the United States Government nor any agency Thereof, nor any of their employees, makes any warranty, express or implied, or assumes any legal liability or responsibility for the accuracy, completeness, or usefulness of any information, apparatus, product, or process disclosed, or represents that its use would not infringe privately owned rights. Reference herein to any specific commercial product, process, or service by trade name, trademark, manufacturer, or otherwise does not necessarily constitute or imply its endorsement, recommendation, or favoring by the United States Government or any agency thereof. The views and opinions of authors expressed herein do not necessarily state or reflect those of the United States Government or any agency thereof. 


\section{DISCLAIMER}

Portions of this document may be illegible in electronic image products. Images are produced from the best available original document. 
This report has been reproduced directly from the best available copy.

Available from the National Technical Information Service, U. S. Department of Commerce, Springfield, Virginia 22161.

\author{
Price: Printed Copy A04
}

Microfiche A01

Codes are used for pricing all publications. The code is determined by the number of pages in the publication. Information pertaining to the pricing codes can be found in the current issues of the following publications, which are generally available in most libraries: Energy Research Abstracts, (ERA); Government Reports Announcements and Index (GRA and I); Scientific and Technical Abstract Reports (STAR); and publication, NTIS-PR-360 available from (NTIS) at the above address. 


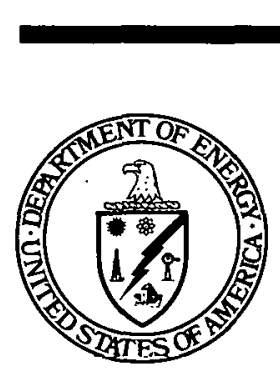

\section{Program Summary for the Civilian Reactor Development Program}

$\mathrm{DOE} / \mathrm{NE}--0041$

DE83 001005

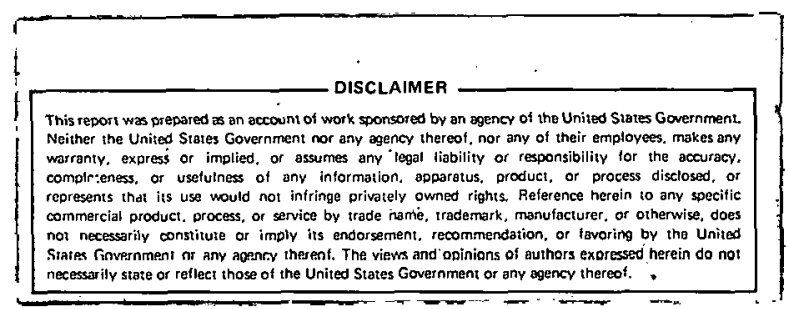




\section{Department of Energy}

Washington, D.C. 20545

\section{PREFACE}

This document was prepared by the Office of the Deputy Assistant Secretary for Breeder Reactor Programs, Department of Energy. It presents a summary of the fission energy program implementation plan as of June 1982 and is based on the Reagan Administration's policies as set forth in Congressional testimony and budget narratives. As this report was going to press, the office of the Assistant Secretary for Nuclear Energy was reorganized. Hence, the organizational structures shown are no longer correct.

Section I provides a statement of the overall program objectives and a general program overview. Section II discusses the objectives, implementation strategy, accomplishments, and funding and schedules of the civilian fission reactor power development programs. Section III details the program management, as well as the structure and methods used for program control. The Appendixes provide background information on fission energy and the civilian reactor development program.

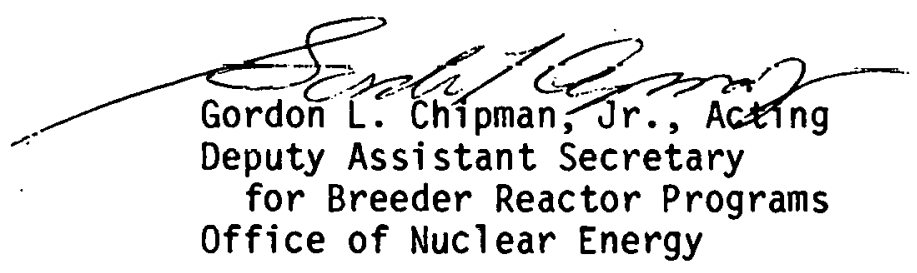




\section{TABLE OF CONTENTS}

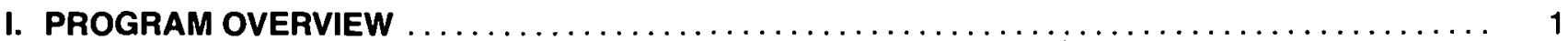

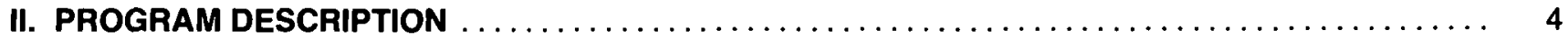

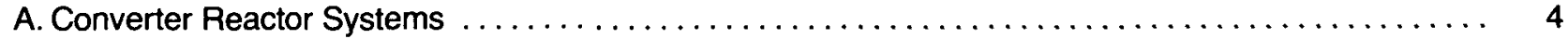

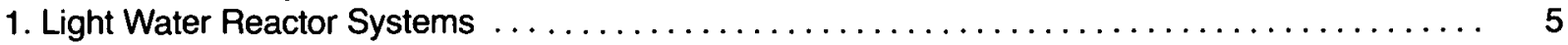

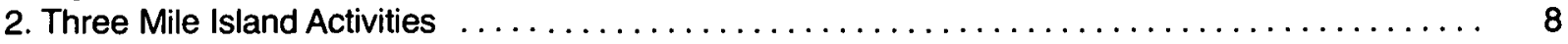

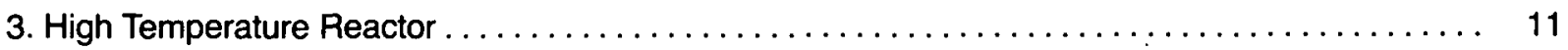

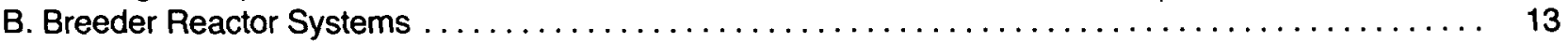

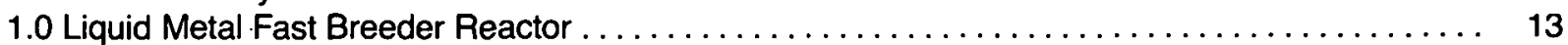

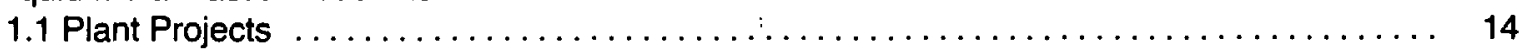

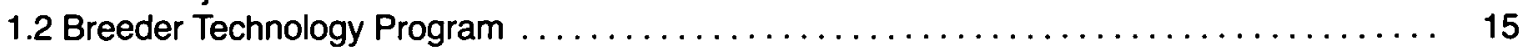

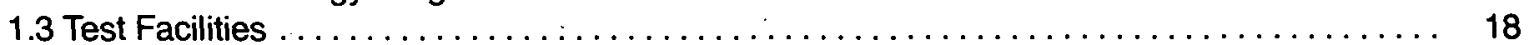

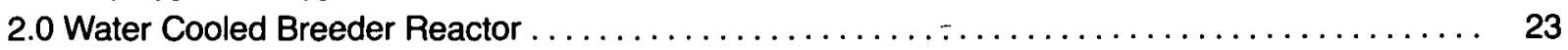

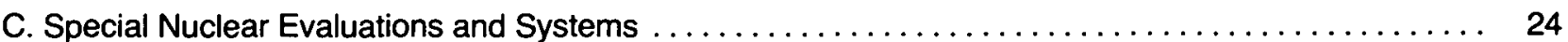

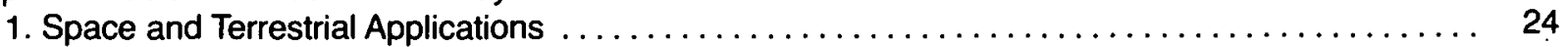

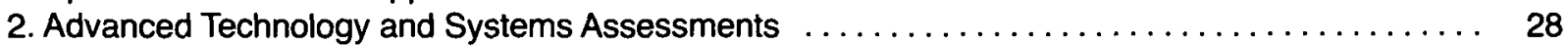

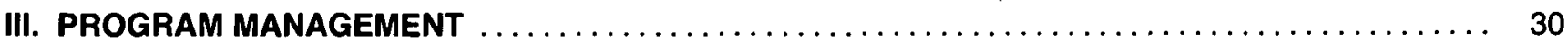

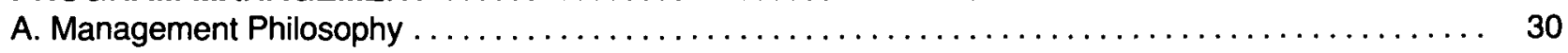

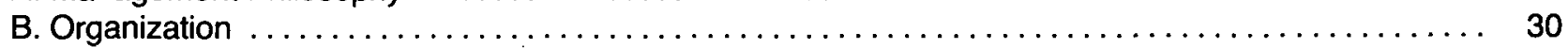

C. Program Assurance, Safeguards and Security $\ldots \ldots \ldots \ldots \ldots \ldots \ldots \ldots \ldots \ldots \ldots \ldots \ldots \ldots \ldots \ldots$

\section{APPENDIXES}

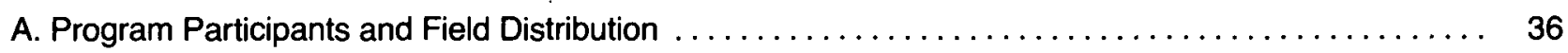

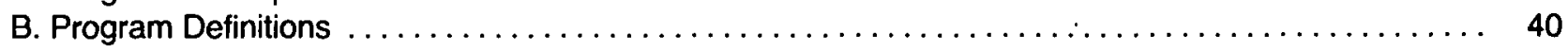

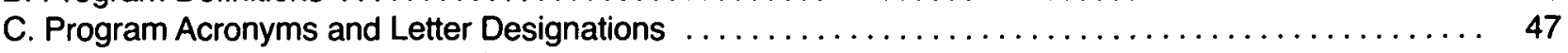

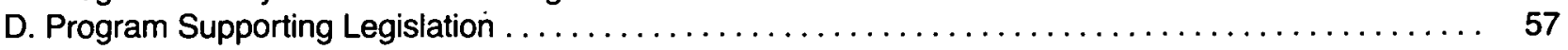




\section{PROGRAM SUMMARY FOR THE CIVILIAN REACTOR DEVELOPMENT PROGRAM}

\section{PROGRAM OVERVIEW}

This Civilian Reactor Development Program document has the prime purpose of summarizing the technical programs supported by the FY 1983 budget request. This section provides a statement of the overall program objectives and a general program overview. Section II presents the technical programs in a format intended to show logical technical interrelationships, and does not necessarily follow the structure of the formal budget presentation. Section III presents the technical organization and management structure of the program.

Today nuclear energy provides about 12 percent of our country's total electrical supply. This year it is projected to become the second largest generator of electricity, surpassed only by coal. By 1990, as additional plants in the pipeline begin operation, its contribution will increase to between 22 and 25 percent. The nuclear option is capable of providing hundreds of years of economic electrical power, independent of foreign energy sources, while allowing us to conserve our fossil fuel for other critical applications. Achievement of this goal is predicated on the establishment of a fully integrated nuclear fuel cycle and power generation system. The essential elements of this system include (1) a smoothly functioning light water reactor (LWR) industry; (2) a completed fuel cycle including effective reprocessing and waste management systems; and (3) the timely introduction of the breeder reactor. The Civilian Reactor Development Program is concerned primarily with the first and third of these elements.

On October 8th of last year, President Reagan announced a revised nuclear pollcy that recognizes both the potential of nuclear energy and the impediments currently restricting its full use. To remove these barriers and allow nuclear power to compete, free of constraint, In the marketplace, several major policy initiatives were announced. They iriclude regulatory and licensing reform and resurnption of breeder development, including completion of the Clinch River Breeder Reactor (CRBR). These directives provide the major thrust for the Civilian Reactor Development Program.

Highlights of the major areas comprising the Civilian Reactor Development Program are as follows:

\section{CONVERTER REACTOR SYSTEMS}

The overall objective of the Converter Reactor Systems Program is to enhance the utilization of domestic energy resources through the use of light water reactor technology already in widespread use. The principal ongoing programs in this area are the safety and fuel performance of LWRs and the cleanup and other remedial actions required at the Three Mile Island (TMI) plant.

LWR Safety. The objective of the LWR Safety program is to formulate, coordinate, and conduct $R \& D$ to improve reactor safety and to support revitalization of the LWR energy option. To achieve this objective, the Department will coordinate the development and implementation of a DOE/NRC/Industry cooperative program that (1) defines the institutional and technological issues of priority in achieving these goals; and (2) identifies the efforts required to resolve these issues.

LWR Extended Burnup. The principal purpose in extending the burnup of LWR fuel is to reduce the generation rate of spent fuel and thereby reduce spent fuel storage and reprocessing requirements. Extended burnup can improve fuel cycle economics and the utilization of uranium resources. In FY 1983 the subprogram will be focused to include proving through demonstration the performance of a single extended burnup fuel design up to established goal burnups, obtaining licensing data to support that and other extended burnup designs, and developing other necessary supporting technology.

Three Mile Island. The overall goal of the Department's Three Mile Island activities has been to develop and improve measures for enhancing safety and reliability of nuclear powerplants and to improve the capability to decontaminate nuclear powerplants. To accomplish this goal, DOE is pursuing a program of carefully examining and evaluating the TMI-2 accident and the response of the nuclear powerplant components and systems to accidents. In consonance with the Administration's policy of placing responsibility for commercial nuclear power activities in the private sector, the Department's TMI program is limited to necessary research and development only.

The TMl activity has two major program elements: (1) a TMI Reactor Evaluation and Waste Immobilization Program that was initiated in FY 1982, and (2) a TMI Data Acquisition Program that began in FY 1980.

\section{BREEDER REACTOR SYSTEMS}

This Nation needs a breeder reactor industrial capability to meet future demands for electricity. Although future electric growth will likely be lower than the high rates 
experienced before the 1973 oil embargo, the 2.5 to 3.5 percent electric growth rates typically projected for the long term will require a doubling of the current installed capacity of $640 \mathrm{GWe}$ within the next 20 to 30 years. The breeder can be the most economical technology for supplying electricity when it reaches technical maturity, and it could become a valuable source of foreign trade benefits. Additionally, the breeder reactor can provide less environmental impact than current generation light water reactors (LWRs).

Development of the fast breeder reactor to meet longterm energy needs has been the ultimate goal of the Federal civilian nuclear program for the past two decades. However, there are nearer-term incentives because continued breeder development is also essential to future expansion of the current LWR nuclear system since it demonstrates the Government's commitment to nuclear energy, it will close the nuclear fuel cycle, and it will cap the cost of nuclear power by eliminating the need to mine uranium over the long term.

A Federal role is necessary because the costs and risks of development are higher than the private sector can bear, and the benefits are capturable only over a long period of time. The Nation's breeder program has benefited from over $\mathbf{3 0}$ years of successful research, development, and demonstration (RD\&D) support. The achievements are part of a natural progression in size and complexity that will lead to decisions by the private sector on breeder industrialization and deployment.

The Federal role in the future of breeder reactors is to conduct the necessary research and development such that the potential benefits of the breeder can be captured by private industry at a venture risk level that is consistent with acceptable business endeavors. The responsibility for industrialization and deployment will rest with the private sector.

For more than two decades, the major breeder reactor research and development activities have concentrated upon the liquid metal fast breeder reactor (LMFBR). In 1965 , a smaller program was established to examine the feasibility of a water cooled breeder.

LMFBR Program. The current LMFBR program began in the 1960's, and the goals of the program became more highly focused in the mid 1970's when the United States adopted the policy of developing several long-term options for providing energy from inexhaustible and renewable energy sources. Effort was concentrated on three technologies: fusion, solar electric systems, and the fast breeder reactor. Ninety-five percent of our total energy still comes from scarce and depletable resources; hence the need to develop inexhaustible technologies is even more vital today, nearly a decade later. While other inexhaustible electrical energy sources, such as fusion and solar electric, may become available to compete on an economic, technical, and commmercial basis with the breeder, the advanced state of fast breeder technology relative to fusion and solar make it the surest of the inexhaustible supply options.

The goal of the LMFBR program is to ensure that this long-term electricity supply option is available on a prudent time scale. To accomplish this goal, the U.S. LMFBR program will develop the technical, engineering, safety, environmental, economic, licensing, and industrial data base required to transfer design, construction, and operation capabilities of future LMFBR powerplants to the private sector. The program consists of three broad elements: (1) design, construction, and operation of developmental plants; (2) a supporting base technology program, including test facility construction and operation; and (3) a supporting fuel cycle program. The first two elements are closely integrated and are directed at breeder powerplant development, while the fuel cycle effort will provide the basis for integrating breeder reactors into an existing and expanded nuclear energy economy.

To bring this technology to a point of acceptable commercial risk requires that it be advanced and confirmed by constructing and operating plants in increasingly larger sizes. This approach was followed by the Atomic Energy Commission in cooperation with the electric utilities to achieve the successful commercialization of LWRs. This approach is also being used by the major foreign breeder development programs. The LMFBR program has successfully constructed and operated the $20 \mathrm{MWe}$ EBR-II and the 133 MWe equivalent Fast Flux Test Facility (FFTF).

DOE is proceeding with the 375 MWe Clinch River Breeder Reactor Plant (CRBRP), and is entering a new phase in which Government is encouraging and supporting construction of a large-scale prototype breeder plant. The pre-commercial plant will be principally funded by the private sector.

The deployment of any new technology is a lengthy process; and timely development of all inexhaustibles is necessary so that their technical and economic viability can be demonstrated so that they can effectively compete and displace scarce energy resources in the marketplace. While we cannot say with certainty exactly when the breeder will be needed anymore than we can say when solar electric systems and fusion will be needed, the strategy of the current program is to continue development of fast breeder technology so that it will be available for commercial development by the private sector. This approach ensures the most effective use of resources and positions the technology so that it will be available early next century.

Water Cooled Breeder. The goal of this program is to develop technology for significantly improving the efficiency of nuclear fuel resource utilization by water cooled reactors. Operation of the Shippingport Atomic Power Station using a light water breeder reactor (LWBR) core will continue through the life of the present core. Following this period of operation, the performance of the core and the breeding ratio will be assessed. 
SPECIAL NUCLEAR EVALUATIONS AND SYSTEMS

Space and Terrestrial Applications. Work is continuing on the development of viable power systems for space missions to be launched in the mid-1980's, and on the demonstration of beneficial uses of radioisotopes in various terrestrial applications.

\section{FUNDING}

Funding for the civilian reactor development program for FY 1981 and FY 1982 and the request for FY 1983 is shown in the following table, arranged in the order of presentation in this document.

\section{CIVILIAN REACTOR DEVELOPMENT PROGRAM}

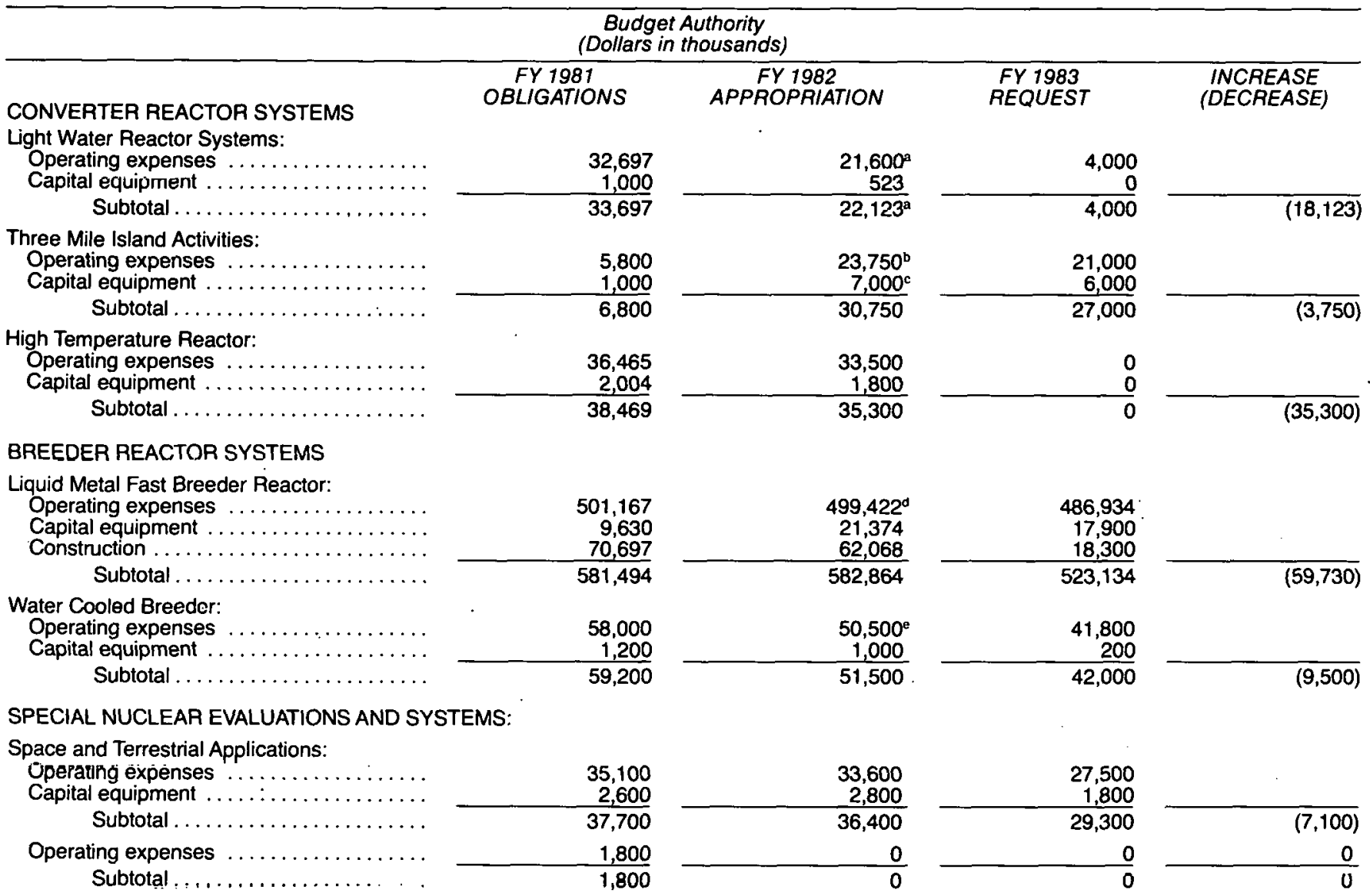

a Reflects $\$ 600,000$ reduction transferred to Solar and Renewables programs.

beflects a $\$ 1,000,000$ reduction in operating funds in accordance with Fiske memo; dated $3 / 3 / 82$, to cover severe reductions in Solar and Renewables Programs.

c Reflects a $\$ 1,000,000$ reduction in capital equipment funds in accordance with Fiske memo, dated 3/5/82, to cover critical funding shortage in the Departmental Administration account.

- Reflects reduction of $\$ 2,200,000$ for reprogramming to Solar and Departmental Administration.

- Reflects reduction of $\$ 500,000$ for reprogramming to Solar. 


\section{PROGRAM DESCRIPTION}

This section provides the objectives and description of each major element of the nuclear reactor program; discusses program implementation and strategy; and presents accomplishments, milestones and budget resources.

\section{A. CONVERTER REACTOR SYSTEMS}

The current generation of commercial power reactors in the United States are converter reactor systems which utilize low-enrichment uranium oxide fuel and are light water moderated and cooled. Converter reactors are those characterized by a fuel conversion ratio less than one; i.e., fissile material is consumed by the reactor faster than it is generated. This type of reactor currently produces almost all of the nuclear energy commercially available in the United States. A more detailed description of converter reactors, as well as all types of fission energy systems, is given in Appendix B.

This chapter describes the DOE programs concerned with converter reactor systems and their continued use as a source of safe, economic, and reliable nuclear power.

\section{Overview}

Background. In the early 1950s, the existence of the light water reactor (LWR) technology developed through research work conducted in the naval propulsion reactor program, the uranium enrichment capacity built during World War II, and a large quantity of indigenous uranium resources led quite logically to the development of light water reactors as electric power producers. The resulting commercialization of nuclear power using LWRs was promoted by Federal policies, as exemplified by the Atomic Energy Act of 1954, which encouraged the peaceful uses of atomic energy by the private sector. By the early 1970s, these policies and the economic advantages and reliability of nuclear plants had resulted in a selfsufficient industry capable of producing a number of commercial nuclear powerplants each year.
Objective. The principal objective of the Converter Reactor Program is to improve the efficient and safe use of domestic nuclear energy resources through improvements in LWR technology and by contributing to the resolution of the nuclear industry's institutional problems.

Strategy. The major programs being implemented are the Light Water Reactor Systems program and Three-Mile -Island (TMI) activities. The High Temperature Reactor (HTR) program has also been included in this program area through FY 1982, but is proposed for cancellation in FY 1983. In the LWR and TMI programs, improved technologies are being developed, particularly in the safety area. The results of these efforts are expected to enhance the attractiveness to utilities of increasing the deployment of conventional nuclear power.

Management. The DOE Headquarters organizations responsible for directing these programs are shown in the upper level work breakdown structure (WBS) and Department of Energy (DOE) responsibility matrix of Figure 1.

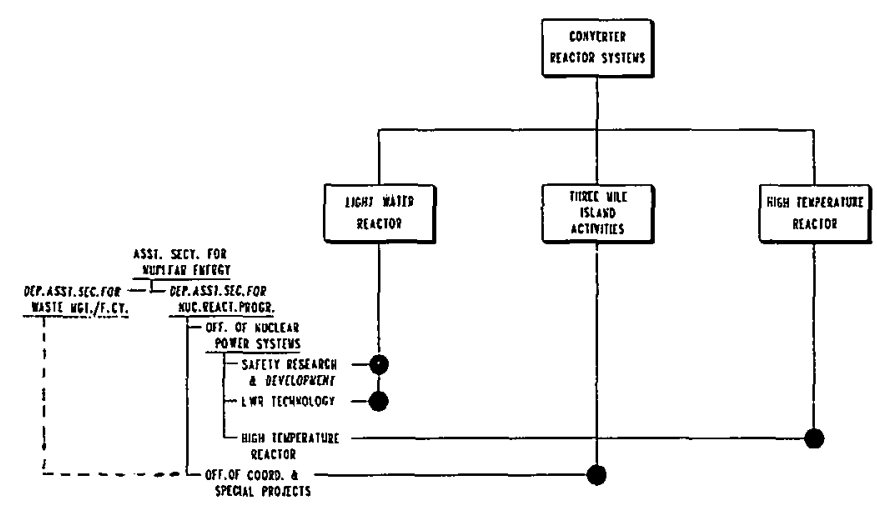

Figure 1. Converter Reactor Systems upper level work breakdown structure and DOE responsibility matrix.

Funding. The following table shows the operating funding levels by program element for the FY 1981 through FY 1983 period.

CONVERTER REACTOR SYSTEMS

\begin{tabular}{|c|c|c|c|c|}
\hline \multirow[b]{2}{*}{ PROGRAM ELEMENT } & \multicolumn{4}{|c|}{$\begin{array}{c}\text { BUDGET AUTHORITY } \\
\text { (DOLLARS IN THOUSANDS) }\end{array}$} \\
\hline & $\begin{array}{l}\text { OBLIGATIONS } \\
\text { FY } 1981\end{array}$ & $\begin{array}{c}\text { APPROPAIATIONS } \\
\text { FY } 1982\end{array}$ & $\begin{array}{l}\text { REQUEST } \\
F Y 1983\end{array}$ & $\begin{array}{c}\text { INCREASE } \\
\text { (DECREASE) }\end{array}$ \\
\hline $\begin{array}{l}\text { LIGHT WATER REACTORS } \\
\text { THREE MILE ISLAND } \\
\text { HIGH TEMPERATURE REACTOR }\end{array}$ & $\begin{array}{r}32,697 \\
5,800 \\
36,465\end{array}$ & $\begin{array}{l}21,600 \\
23,750 \\
33,500\end{array}$ & $\begin{array}{r}4,000 \\
21,000 \\
0\end{array}$ & $\begin{array}{r}(17,600) \\
(2,750) \\
(33,500) \\
\end{array}$ \\
\hline TOTAL & 74,962 & 78,850 & 25,000 & $(53,850)$ \\
\hline
\end{tabular}




\section{Light Water Reactor Systems}

Since FY 1976, the Light Water Reactor (LWR) program has been concerned with developing and demonstrating advances in the technology as a means for preserving and enhancing the LWR option in the United States. The current emphasis of the LWR Systems Program is to support revitalization of the LWR energy option by contributing to the resolution of the nuclear industry's institutional problems. When electric demand dictates, additional nuclear capacity will be sought provided that institutional and financial obstacles are overcome. These obstacles are difficulties in capital formation by utilities, instability of regulatory process, and public perception of nuclear power. There is no intrinsic reason why it should take between 10 and 15 years to bring nuclear plants into operation in the United States, when plants in France and Japan can be licensed and constructed in about 5-7 years. One correctable reason this condition exists is the uncertainty that a utility must face throughout the entire regulatory process, including the construction period and even after plant operation begins. The utilities and their investors cannot cope with the resulting uncertainty and significant costs over a 10-15 year time period. In addition, it impacts the public's confidence and perceptions of the ability of industry to provide reliable, economic, and safe nuclear power. The Vice President's Task Force on Regulatory Reform offers an opportunity to correct much of this problem. The strategy for DOE is to coordinate and participate in the development and implementation of a DOE/NRC/ Industry cooperative program that identifies the institutional and technological issues that must be resolved and defines the efforts required to resolve these issues.

The LWR program is comprised of three elements: The LWR Safety Program, LWR Extended Burnup Program, and the Radiation Dose Reduction Program.

\section{a. Light Water Reactor Safety Program}

Objectives. The objectives of the LWR Safety Program are to encourage development of a technical basis to support LWR industry institutional improvements, in particular, nuclear regulatory reform; and, consistent with requirements of the Nuclear Safety Research, Development, and Demonstration Act of 1980 (Public Law 96-567), to develop a technical basis to effect improvements in the ability of LWR industry to produce reliable, economical, and safe nuclear power.

Description. To achieve the above objective, the Department will coordinate the development and implementation of a DOE/NRC/Industry cooperative program that:

- Defines the institutional and technological issues of priority in achieving these goals; and

- Identifies the eftorts required to resolve these issues.

A key effort in this program is the development of a systematic and integrated approach to LWR safety.

The program is divided into two phases--a program definition phase and a program implementation phase.
Program needs and priorities are being defined by utilizing working groups composed of representatives from DOE, NRC, industry, and national laboratories to assist the DOE in both the program definition and program implementation phases. DOE has convened eight of these working groups and their membership and schedule of activities have been provided to Congress in our response to Public Law 96567. Current activities are indicated in the accomplishments section.

Implementation/Strategy. The ultimate responsibility for safe economic generation of nuclear power lies with the utility owners of nuclear powerplants. In some instances because of the institutional structure, the respective roles of the utilities and regulators in assuring the safety of nuclear powerplants have become unclear and the utilities have not been able to discharge this responsibility in an optimum fashion. Efforts to modify nuclear power institutions to improve the ability of the nuclear industry to produce safe, economical power are focused on reestablishing and clearly delineating the proper authorities and responsibilities of the industry and regulatory bodies. To accomplish this, a systematic integrated approach to LWR safety is being developed; demonstrated, and implemented.

In response to Public Law 96-567, and to meet the objectives of the program, the Department will coordinate this comprehensive LWR Safety R\&D Program with industry, NRC, national laboratories, other Government bodies, and foreign programs.

Accomplishments. Major accomplishments in FY 1981 were:

- Transfer of advanced analytic safety technology to industry through cooperative projects in the areas of risk/cost/benefit methodology, task analyses of reactor operations, nuclear plant reliability, and safety parameter display system formats.

- Development of an approach for modifying the LWR nuclear plant fission product source term vital in plant siting and emergency preparedness.

Major accomplishments in FY 1982 include the submittal by the Department to the Congress of the three specific studies required by Public Law 96-567:

- A Comprehensive Program Management Plan

- A study of the need and feasibility of a National Reactor Engineering Simulator

- A study of the sufficiency of U.S. efforts to provide specially trained operators for nuclear plants.

The completed or planned FY 1982 accomplishments also include:

- Successful completion of the containment sump emergency performance experimental program at Alden Research Laboratory to provide a definitive data base to remove this longstanding NRC generic safety issue from the "unresolved safety issue" list. 
- Complete development of a fire hazards analysis technique that will provide an optimum approach to protect essential nuclear powerplant safety systems from fire hazards.

- Complete development of a Probabilistic Risk Assessment Guidebook to provide guidance for performing risk analyses. This effort is jointly sponsored with the Nuclear Regulatory Commission, the Institute of Electrical and Electronics Engineers, and the American Nuclear Society.

- Complete the evaluation of the Boiling Water Reactor Safety Parameter Display System with the utility owners group on a powerplant simulator to assess the actual advantages of incorporating this system in the control room in response to a proposed NRC rule.

- Complete the demonstration of a common cause failure analysis technique through a cooperative program with the Duke Power Company and Idaho National Engineering Laboratory.

- In cooperation with the Institute of Nuclear Power Operations (INPO), conducted an overall assessment of utility manpower and training and an analysis of operator skill and job requirements. In addition, assisted INPO by developing an operating procedure evaluation handbook in FY 1982. 1983 will:

The LWR Safety Program's planned activities in FY

- Continue efforts to examine and take actions to ameliorate regulatory impacts, such as determining if sufficient technical basis exists in data already available from Government sponsored programs to warrant relaxation of the overly conservative assumptions in 10 CFR 50 Appendix K.

- Coordinate and maintain the comprehensive LWR Safety Program plan as directed in Public Law 96567.

- Continue R\&D efforts to simplify plant control and operations in order to provide more effective management of off-normal events.

\section{b. LWR Extended Burnup}

Objectives. The objective of the Extended Burnup program is to develop and demonstrate the technology to extend the burnup of LWR fuel. Extended burnup serves to reduce the volume of spent fuel generated by LWR's, which relieves the pressure on the back end of the LWR fuel cycle.

Description. The Extended Burnup program is an element of the former Uranium Utilization program under which major projects involving all 5 domestic fuel vendors were initiated with 11 U.S. utilities for irradiation demonstrations in 11 power reactors. In FY 1982 the program was narrowed to develop and demonstrate extended bur- nup for various fuel designs including advanced designs capable of achieving the program target values or higher. In FY 1983, to achieve the program's objective at minimum cost, the Extended Burnup program will continue the demonstration of only one fuel design, and work on all other designs will be closed out. Several technology development projects generating basic generic data on extended burnup phenomena needed for design and licensing will also be continued at a low funding level. With the completion of these projects, much of the fuel performance and design information required to permit major increases in burnup from today's discharge level should be obtained. Burnup increases to the program target levels of 50,000 MWd Mt for pressurized water reactors (PWR's) and 45,$000 \mathrm{MWd}$ Mt for boiling water reaclors (BWR's) will result in an annual reduction in spent fuel of 40 percent, a reduction in nuclear fuel cycle cost of over 10 percent, a reduction in near-term uranium requirements of 15 percent, and a reduction in separative work unit requirements of 2 percent.

Implementation/Strategy. The approach is to demonstrate extended burnup for one fuel design, develop the basic data needed for design and licensing, and rely on competitive market forces for industry-wide implementation.

Accomplishments. Significant accomplishments that have been made prior to FY 1983 include the following:

- Four lead test assemblies with an advanced high burnup fuel design were placed under irradiation in Arkansas Power and Light Company's Arkansas Nuclear One reactor.

- Following irradiation of four lead test assemblies, core-wide implementation of axial blankets was initiated in Sacramento Municlpal Utillty Districl's Ranicho Seco reactor.

- Following irradiation of four lead test assemblies and completion of test reactor irradiations, a large-scale demonstration of 144 assemblies with cladding resistant to pellet-cladding interaction failures was initiated in Commonwealth Edison Company's Quad-Cities Station, Unit 2 reactor.

- Two assemblies of current design fuel with hurnups in excess of $40,000 \mathrm{MWd} / \mathrm{Mt}$ were continuing irradiation to burnups in excess of 50,000 MWd/Mt, one in Duke Power Company's Oconee Nuclear Station Unit 1 reactor and one in Omaha Public Power District's Ft. Calhoun Station reactor.

- The irradiation of two assemblies of current design fuel to 45,000 MWd/Mt was completed in Northern States Power Company's Monticello reactor.

- The irradiation of advanced fuel rod designs for high burnup was initiated in Arkansas Power and Light Company's Unit 2 reactor.

- Irradiation was completed on 59 fuel rods to high burnup and irradiation continued on 359 fuel rods to 
demonstrate pellet-cladding-interaction remedies in Consumers Power Company's Big Rock Point reactor.

- Irradiation of one assembly to 42,500 MWd/Mt was completed in Virginia Electric and Power Company's Surry 2 reactor.

The planned accomplishments for the Extended Burnup program in FY 1983 and beyond include the following:

- Select the single extended burnup fuel design to be proved out under Department sponsorship and initiate the contract actions (principally cancellations of similar work on other designs) to implement this selection.

- Continue to prove the performance of a single extended burnup fuel design up to established goal burnups.

- Continue to obtain generic design and licensing data and other necessary supporting technology.

- Complete four projects in the areas of fission gas release, $\mathrm{PCl}$ remedies, fuel storage, and fuel shipping.

\section{c. Radiation Dose Reduction Technology}

Objective. The objective of this program element has been to develop and demonstrate technology to reduce the occupational radiation exposure to LWR plant personnel.

Description. The broad approach to reducing radiation exposures has two major thrusts: (1) to develop and demonstrate techniques to reduce the radiation sources, thereby reducing the radiation fields where the work is performed, and (2) to develop and demonstrate techniques that reduce the time or need for a worker to be in the radiation field. By reducing the sources of radiation and/or time spent in radiation fields, the continuing increases in total LWR radiation exposures and the resulting adverse impact on availability of sufficient manpower to operate and maintain these plants can be arrested.

\section{(1) Reduction of Radiation Source Level}

Radiation source reduction has the objective of preventing accumulation of radioactive contaminants. This program subelement involves work to help eliminate the physical source of the problem--the radioactive material itself. This can be accomplished through material control, filtration, chemistry, and operational controls or decontamination.

In FY 1982, there were two projects in the chemical decontamination area. One involves the development and demonstration of a process for decontamination of the reactor vessel head. The other involves the demonstration of a thorough hard decontamination process for a defueled BWR to be applied at the Dresden-1 reactor. A feasibility study of dilute chemical processes that can be applied quickly, involve minimum waste disposal, do not involve removal of fuel, and use the primary coolant as part of the solvent has been completed.

\section{(2) Reduction of Time in Exposure Fields}

The major approach to reducing the time in exposure fields is the development of techniques to help eliminate and minimize the need for workers to go into radiation zones to perform special inspections or repair unexpected breakdowns. Another approach to reducing the time in exposure fields is to reduce incidents of failed components or improve the operational and maintenance practices.

Remote surveillance and diagnostics efforts are being completed in two areas: (a) on-line monitoring of whole systems to help plan preventative maintenance, and (b) remote monitoring of particular problem components. Projects were conducted on acoustic emission monitoring of BWR components with Philadelphia Electric Company, rotating machinery monitoring with Mississippi Power and Light Company, and reactor coolant pump monitoring with Toledo Edison Company.

Under the strategy to limit radiation exposure by reducing the incidence of component failures, efforts will be completed to reduce flow induced vibration failures, eliminate BWR piping stress corrosion cracking, and prevent PWR steam generator tube failures. The single activity in improvement to operational and maintenance practices has been the development and demonstration of an advanced technique for managing and controlling radiation exposure during outages.

Implementation/Strategy. In FY 1982, the funding was reduced to a level that allows the orderly closeout of the Dose Reduction program. Existing projects that were in place at the end of FY 1981 will be completed with FY 1982 and prior-year budget authority. This strategy permits key results to be salvaged, most of the past investment to be protected, and many of the national benefits of the program to be attained, consistent with a rapid but still feasible transition of key projects to private sector sponsorship.

Accomplishments. In FY 1982, the Dose Reduction program began an orderly wrap-up and no new projects were initiated. Of the eight remaining projects, four were completed in FY 1982 and the other projects will be completed by the end of FY 1985.

The significant accomplishments for FY 1982 are the following:

- Issuance of industry-wide design guides on reducing flow induced vibration failures in plants.

- Issuance of an NRC waiver for substitution of remote acoustic emission monitoring for manual inservice inspection of piping at Peach Bottom-3.

- Completion of safety and environmental review by the NRC staff in preparation for a strong chemical decontamination of the defueled Dresden-1 reactor.

- Technical and economical feasibility studies of on-line and off-line methods for preventing PWR steam generator tube failures.

- Demonstration at Dresden-2 of a process for preventing BWR piping stress corrosion cracking. 
Resources. The following table shows the operating funding levels by program element for the FY 1981 through FY 1983 period.

LIGHT WATER REACTOR SYSTEMS

\begin{tabular}{|c|c|c|c|c|}
\hline \multirow[b]{2}{*}{ PROGRAM ELEMENT } & \multicolumn{4}{|c|}{$\begin{array}{c}\text { BUDGET AUTHORITY } \\
\text { (DOLLARS IN THOUSANDS) }\end{array}$} \\
\hline & $\begin{array}{l}\text { OBLIGATIONS } \\
\text { FY } 1981\end{array}$ & $\begin{array}{c}\text { APPROPRIATIONS } \\
\text { FY } 1982\end{array}$ & $\begin{array}{l}\text { REQUEST } \\
\text { FY } 1983\end{array}$ & $\begin{array}{l}\text { INCREASE } \\
\text { (DECREASE) }\end{array}$ \\
\hline $\begin{array}{l}\text { SAFETY } \\
\text { EXTENDED BURNUP } \\
\text { RADIATION DOSE REDUCTION }\end{array}$ & $\begin{array}{c}7,398 \\
16,595 \\
8,704\end{array}$ & $\begin{array}{r}10,300^{2} \\
11,000 \\
300\end{array}$ & $\begin{array}{c}1,000 \\
3,000 \\
0\end{array}$ & $\begin{array}{r}(9,300) \\
(8,000) \\
(300)\end{array}$ \\
\hline$\overline{\text { TOTAL }}$ & 32,697 & $21,600^{9}$ & 4,000 & $(17,600)$ \\
\hline
\end{tabular}

a Reflects $\$ 600,000$ reduction transferred to Solar and Renewable Resources.

$\mathrm{b}$ In prior years this program element was designated Radiation Dose Reduction/Productivity.

Milestones. Major milestones for the Light Water Reactor Systems program are given in the following chart.

CONVERTER REACTOR SYSTEMS

LIGIT WATER RLACTOR SYGTENS

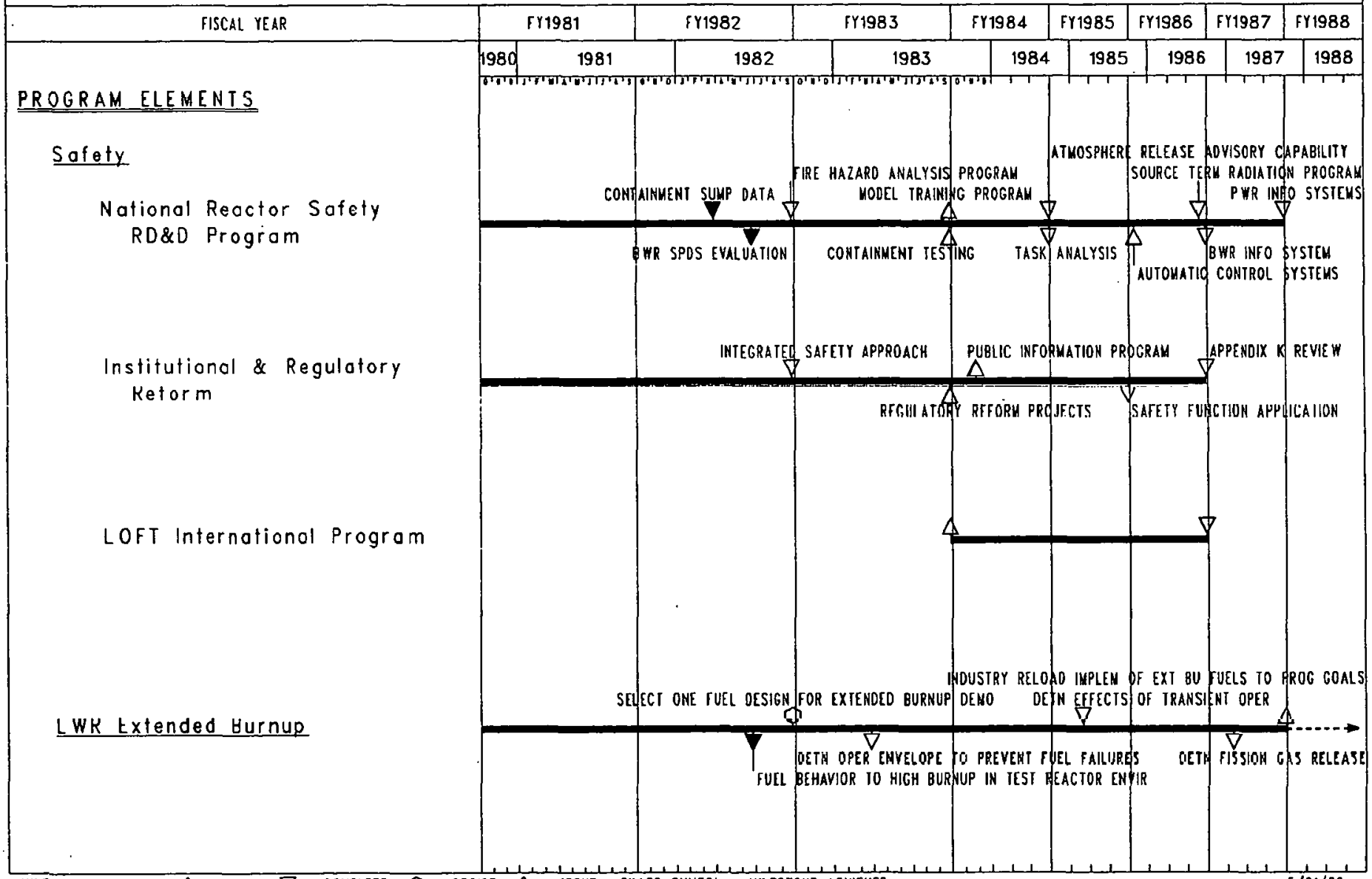

YILESTONE SYMBOLS: $\triangle=$ BEGN; $\nabla=$ COMPLETE; $O=$ DECIDE; $O=15$ SUE. FILLEO SYMBOL = MILESTONE ACHIEYEO.

\section{Three Mile Island Activities}

The Three Mile Island (TMI) Unit 2 accident of March 28, 1979, was and is of great concern to the electric industry, its customers, regulatory and other Government agencies, and the country as a whole. While the accident resulted in very limited radiation exposure to the population surrounding the powerplant (the Kemeny Commission concluded that the average radiation dose to a person living within 5 miles of TMI was about 10 percent or less than the annual background radiation), extensive damage resulted to the plant itself, with high radiation contamination within the reactor and supporting systems and facilities. The TMI-2 accident presents unique opportunities to ac- 
cumulate information for the enhancement of nuclear powerplant safety and reliability of generic benefit to nuclear power technology. The environmental conditions within the containment and the reactor and auxiliary systems pose technically challenging decontamination and radioactive waste management situations. These circumstances represent opportunities for state-of-the-art advancement not available through normal research, development, and test programs. Consequently, the program should obtain significant information to result in the general improvement of light water reactor plant safety, reliability, regulation, and operation.

Objectives. The overall objective of the TMI program is to develop and improve measures for enhancing the safety and reliability of nuclear powerplants, and to improve the capability to decontaminate civilian nuclear powerplants.

The DOE program has two major elements:

(1) TMI Waste Immobilization and Reactor Evaluation (WIRE) Program-The objectives of this program are: (1) to conduct research and development on immobilization of abnormal reactor waste products, and (2) to examine the TMI-2 reactor and core components and to conduct research and development associated with the reactor defueling to provide data for evaluating licensing criteria and requirements, analyzing causes and consequences of accidents, and improving the reliability of the design and operation of LWR's.

(2) TMI Data Acquisition Program (DAP)--The objective of this program is to obtain important research and development data that are of generic value to the safety of light water reactors.

Description. The Department of Energy is moving forward with a Three Mile Island research and development program to provide valuable data related to nuclear safety and cleanup technology. This program will also provide technical support to the General Public Utilities (GPU) Company for prompt, safe, and efficient fuel removal and waste handling operations.

The waste management and immobilization activities will initially be focused on an effort to demonstrate the feasibility of vitrifying zeolite ion exchange materials. The program will have demonstrated this feasibility in FY 1982. In addition, the majority of the Submerged Demineralizer System (SDS) liners and the EPICOR-II liners will be shipped from TMI to Government facilities for R\&D purposes.

Beginning in FY 1983, this program will focus on other techniques for the treatment of abnormal wastes produced at TMI, including alternative immobilization concepts, confidence testing, and long term sample observation to provide a more extensive data base. The knowledge gained from this program will contribute substantially to the technology for processing and disposing of unique waste forms resulting from commercial nuclear powerplant abnormal operations and accidents.

The reactor evaluation activities include the examination, removal, and disposition of the reactor core and inter- nals; the development of the special systems, equipment, facilities, and processes needed to accomplish these tasks; and the conduct of supporting onsite and offsite fuel examinations, tests, and evaluations. Through-the-head visual examination of accessible parts of the reactor upper internals and core will be accomplished prior to defueling.

In FY 1983, preparations will be made for reactor head and plenum removal and defueling. The purpose of this activity is to obtain data and information on the condition of the reactor core and other internal components, to conduct the development needed for a thorough examination, and to effectively complete the defueling in as low as practical radiation environment. In addition, it is planned to perform offsite examinations of the fuel and debris to characterize the accident effects.

The knowledge gained from this program will provide data required for evaluating present licensing criteria and requirements; developing future licensing criteria; assessing and developing computer models used to analyze the course and consequences of severe accidents and means to mitigate the effects of such accidents; and evaluating improvements to reactor design, operation, and maintenance.

In FY 1983, the data acquisition activities will continue, focusing on additional examination of electrical equipment, radionuclide analysis of samples removed from containment, and developing fuel and core examination techniques. The electrical equipment information will be used to upgrade qualification standards, regulatory guides, and operating and maintenance standards in order to improve operation of nuclear powerplants during transients. The data on radioactive samples will be valuable in assessing the existing models for fission product release that are used in nuclear powerplant licensing.

Implementation/Strategy. The TMI program is being implemented in accordance with a memorandum of understanding signed by DOE, NRC, EPRI, and GPU. The efforts of GPU (owners of TMI-2) are aimed primarily at plant cleanup and recovery. DOE has developed a program work scope which will obtain information that would not normally be obtained from the cleanup efforts. DOE's program is being conducted in a manner which avoids delaying the GPU cleanup schedule.

WIRE-In consonance with the Administration's policy of retaining responsibility for commercial nuclear power activities in the private sector, the Department's TMI program is limited to necessary research and development only. Responsibility for the costs of TMI cleanup remain with the owner, the GPU Company. In FY 1983, some of DOE's TMI research activities, such as in-situ inspection of the reactor core, are expected to have indirect benefits to GPU, and to offset some of their cleanup costs. Such activities will only be conducted if they offer the opportunity to obtain significant generic research information.

In accordance with a Memorandum of Understanding between the Department of Energy and the Nuclear Regulatory Commission, DOE will acquire radioactive waste from TMI for research and development, and for disposal. 
In those cases where there is no research value associated with the waste acquired by DOE, the owner, GPU, has agreed to pay all costs associated with shipment and dispospal.

DAP-DOE and EPRI are each sharing responsibility for portions of this R\&D program scope. Specifically, DOE is funding data gathering, research and development, and information transfer in the following major areas: instrumentation and electrical equipment survivability; behavior of radioactive products; data system and specimen archiving; and offsite fuel debris examination. EPRI has similar responsibility for mechanical and structural component reliability, pressure boundary recharacterization, and decontamination and dose reduction associated with the primary coolant system.

Accomplishments. Major accomplishments prior to FY 100E were:

- A Technical Integration Office was established at TMI to manage the Government's activities under DOE's direction with EG\&G, Idaho, as lead contractor.

- A citizen's monitoring program was sponsored by DOE in cooperation with the State of Pennsylvania. This gave area residents the capability to monitor the levels of radioactivity that might be present in their respective communities prior to, during, and subsequent to venting of krypton from TMI-2.

- A joint computerized data bank was established with EPRI to store and transfer data obtained during this program.

- Many electrical instruments were tested in-situ. Selected instruments were removed for further testing to determine failure modes and effects. Generic design and installation changes were suggested.

- Solid, liquid, and gaseous radioactive samples were taken to determine the pathways for radionuclide release.

- The damage to the reactor building was assessed by means of photographs, visual inspections, and radiation surveys.

- An EPICOR-II liner was shipped to Battelle Columbus Laboratory ànd examined.

- Vitrification was demonstrated as a feasible means of immobilizing the liners from the Submerged Demineralizer System.

- National and international seminars were presented to provide program status and results to the nuclear community.

The planned FY 1982 accomplishments include:

- A new initiative was mounted to examine the TMI-2 reactor and core componenls and to conduct R\&D on immobilization of abnormal reactor waste products.

- A large-scale decontamination exporiment was conducted.

- A high integrity container for disposal of an EPICOR-II liner will be fabricated and tested.

- A program will be implemented to develop an understanding of the hydrogen burn that occurred in the TMI-2 containment.

The planned activities in FY 1983 and beyond include:

- The EPICOR-II and SDS liners will be shipped from TMI and studied at DOE laboratories.

- Other abnormal reactor wastes from TMI will be acquired for research and development.

- The reactor and core components will be examined in-situ. The reactor will be defueled and selected portions and components shipped to hot cells for further examination.

Resources. The following table shows the operating funding levels by program element for the FY 1981 through FY 1983 period.

TMI ACTIVITIES

\begin{tabular}{|c|c|c|c|c|}
\hline \multirow[b]{2}{*}{ PROGRAM ELEMENT } & \multicolumn{4}{|c|}{$\begin{array}{c}\text { BUOGET AUTHORITY } \\
\text { (DOLLARS IN THQUSANDS) }\end{array}$} \\
\hline & $\begin{array}{l}\text { OBLIGATIONS } \\
\text { FY } 1981\end{array}$ & $\begin{array}{c}\text { APPROPRIATIONS } \\
\text { FY } 1982\end{array}$ & $\begin{array}{l}\text { REQUEST } \\
\text { FY } 1983\end{array}$ & $\begin{array}{l}\text { INCREASE } \\
\text { (DECREASE) }\end{array}$ \\
\hline $\begin{array}{l}\text { WASTE IMMOBILIZATION AND } \\
\text { REACTOR EVALUATION }\end{array}$ & 0 & 14.750 & 13,000 & $(1,750)$ \\
\hline DATA ACQUISITION PROGRAM & 5,800 & 9,000 & 8,000 & $(1,000)$ \\
\hline$\overline{\text { TOTAL }}$ & 5,800 & 23,750 & 21,000 & $(2 ; 760)$ \\
\hline
\end{tabular}


Milestones. Major milestones for the TMI program are given in the following chart.

CONVERTER REACTOR SYSTEMS

THRE MILE ISLANO ACTIVIIIES

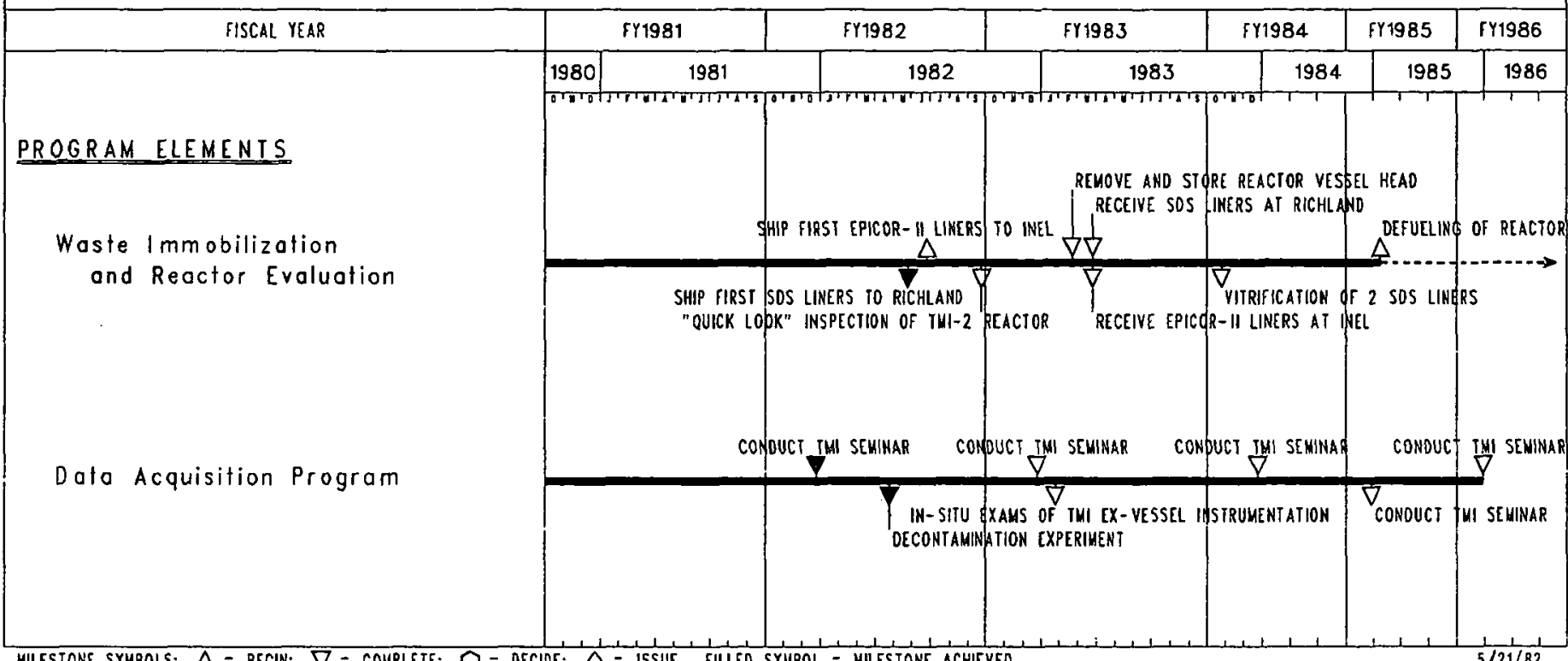

MILESTONE SYMBOLS: $\triangle=$ BEGN; $\nabla=$ COMPLETE; $O=$ DECIDE; $\theta=$ ISSUE, FILLEO SYMBOL = MLLESTONE ACHEYED.

\section{High Temperature Reactors}

The High Temperature Reactor (HTR) is unique among current reactor technologies in its ability to generate nuclear-derived energy in temperature regimes previously limited to fossil fuels. Operating in the lower region of temperature capability $\left(<1300^{\circ} \mathrm{F} / 700^{\circ} \mathrm{C}\right)$, the HTR can be used to generate high-quality steam at conditions equivalent to those produced by conventional fossil-fired steam boilers. In the upper range of temperature capability $\left(>700^{\circ} \mathrm{C}\right)$, an added potential exists for advanced HTR systems. High temperature direct heat can be provided via molten salt or helium and, at temperatures above about $850^{\circ} \mathrm{C}$, the reforming process can be used to produce synthesis gas for long range energy transport or as input to various chemical processes.

Objectives. The objectives of the HTR Program are to develop technology for HTR systems to serve unique energy markets and reduce requirements for oil, natural gas, and coal; and to conduct international cooperation activities where appropriate.

Description. The HTR is classified as an advanced fission converter concept because it provides better fuel utilization than the LWR but not as much as the breeder. It can operate on a variety of uranium and uranium/thorium fuel cycles with both highly enriched uranium and low enriched uranium ( $<20$ percent). Two versions of the HTR are being evaluated for their potential for near-term commercialization. The low temperature version $\left(<1300^{\circ} \mathrm{F}\right)$ is called the steam cycle/cogeneration (HTR-SC/C) design. The high temperature version $\left(>1500^{\circ} \mathrm{F}\right)$ of greatest potential is the reformer system (HTR-R).

In the HTR-SC/C design, reactor thermal energy is used to generate high temperature, high pressure steam for either high efficiency electricity production or for the cogeneration of steam and electricity for process applications. The HTR-SC/C design has evolved through an extensive background of early gas-cooled reactors and demonstration plants.

The HTR-SC/C can serve a large potential market that ranges from baseload electricity generation to industrial cogeneration with central, baseloaded industrial applications such as petroleum refining, enhanced oil recovery, metal refining, and synfuels. In the cogeneration application, the HTR-SC/C differs from the electrical generation application only with respect to how the steam is utilized.

At core outlet temperatures above approximately $850^{\circ} \mathrm{C}\left(1560^{\circ} \mathrm{F}\right)$, the HTR offers a further potential for nuclear process heat. In the HTR-R concept, a portion of the reactor thermal energy is converted to a storable/transportable energy form through the use of a highly endothermic, reversible chemical reaction. (The balance of the reactor thermal energy is used for process steam or for baseload electricity through the conventional steam cycle.) It is this distinguishing feature--the capability of storing and transporting reactor energy--which offers the potential for widespread displacement of fossil fuels (notably gas and oil) by nuclear energy in utility and industrial applications. Since peak reforming temperatures in excess of about $705^{\circ} \mathrm{C}$ $\left(1300^{\circ} \mathrm{F}\right)$ are required for suitable conversion efficiencies, the HTR is uniquely capable of supplying these requirements with nuclear energy. The HTR-R may ultimately provide the nuclear heat source alternative to fossil energy systems in synthetic fuel production, steelmaking, and hydrogen production.

Implementation/Strategy. The strategy for commercialization of the HTR as an energy option is based on the 
following requirements:

- Identification of a sufficient market that serves as a necessary impetus for commercialization.

- Specific utility/users support and commitment that is based on the benefits the HTR system offers.

- An industrial base of vendor/suppliers that are committed to supporting the commercial deployment of the HTR systems.

- Stable Government support and commitment that is based on national benefits and compatibility with other national energy development programs.

In 1980-1981, the technical and economic merits and market characteristics of various HTR systems were evaluated. Through this effort, the $2240 \mathrm{MWt}$ HTR-SC/C system was selected as the primary candidate for near-term commercialization. In cooperation with utility organizations, studies were conducted in four regions of the country which showed promise for deployment of HTR steam cycle systems.

Concurrent with the regional studies, a decision package was prepared that forms the basis for negotiations between the utility/user organizations and the Government for a commitment to construct a Lead Plant. The decision package consists of a lead project strategy plan; a design and cost report; a design and technology development plan; a licensing plan; a management plan; and a conceptual design description.

The Lead Plant project is a four-phase program with a decision point at the end of each phase on whether to continue the project. The Department's decision not to support the HTR Program in FY 1983 is based upon not having developed a favorable industrial commercialization commitment as well as severely constrained budgets. Such an industrial commitment was indicated by the Congress to be a requirement for continued funding. It is our understanding that an industrial response to this Congressional request is being prepared and will be given to the Congress later by them.

Accomplishments. The major accomplishments in FY 1981-82 are:

\section{Lead Plant}

- Conceptual design of a $2240 \mathrm{MWt}$ HTR steam cycle/ cogeneration lead plant is 60 percent complete.

- Technical review of the Lead Plant by program participants, utility representatives, EPRI, and consultants.

- Completion of the regional application survey studies.

- Preparation of the Project Decision Package. Technology

- Completed Fort St. Vrain improvement program activities.

- Initiated conceptual design on process heat and process steam versions of the modular reactor system.

- Continued with the evaluation of graphite and structural metals for very high temperature applications $\left(850^{\circ}-950^{\circ} \mathrm{C}\right)$.

- Continued with the development of the reference LEU uranium oxycarbide (UCO) fuel particles.

Resources. The following table shows the operating funding level by program element for the FY 1981 through FY 1983 period:

HIGH TEMPERATURE REACTORS

\begin{tabular}{|c|c|c|c|c|}
\hline \multirow[b]{2}{*}{ PROGRAM ELEMENT } & \multicolumn{4}{|c|}{$\begin{array}{c}\text { BUDGET AUTHORIIY } \\
\text { (DOLLARS IN THOUSANDS) }\end{array}$} \\
\hline & $\begin{array}{c}\text { OBL/GATIONS } \\
F Y 7981\end{array}$ & $\begin{array}{c}\text { APPROPRIATIONS } \\
\text { FY } 1982\end{array}$ & $\begin{array}{l}\text { REQUEST } \\
\text { FY } 1983\end{array}$ & $\begin{array}{l}\text { INCREASE } \\
\text { (DECREASE) }\end{array}$ \\
\hline $\begin{array}{l}\text { Lead Plant } \\
\text { Technology }\end{array}$ & $\begin{array}{r}0 \\
36,465\end{array}$ & $\begin{array}{r}9,590 \\
23,910\end{array}$ & $\begin{array}{l}0 \\
0\end{array}$ & $\begin{array}{r}(9,590) \\
(23,910)\end{array}$ \\
\hline$\overline{\text { TOTAL }}$ & 36,465 & 33,500 & 0 & $(33,500)$ \\
\hline
\end{tabular}

Milestones. Major milestones for the HTR program are given in the following chart.

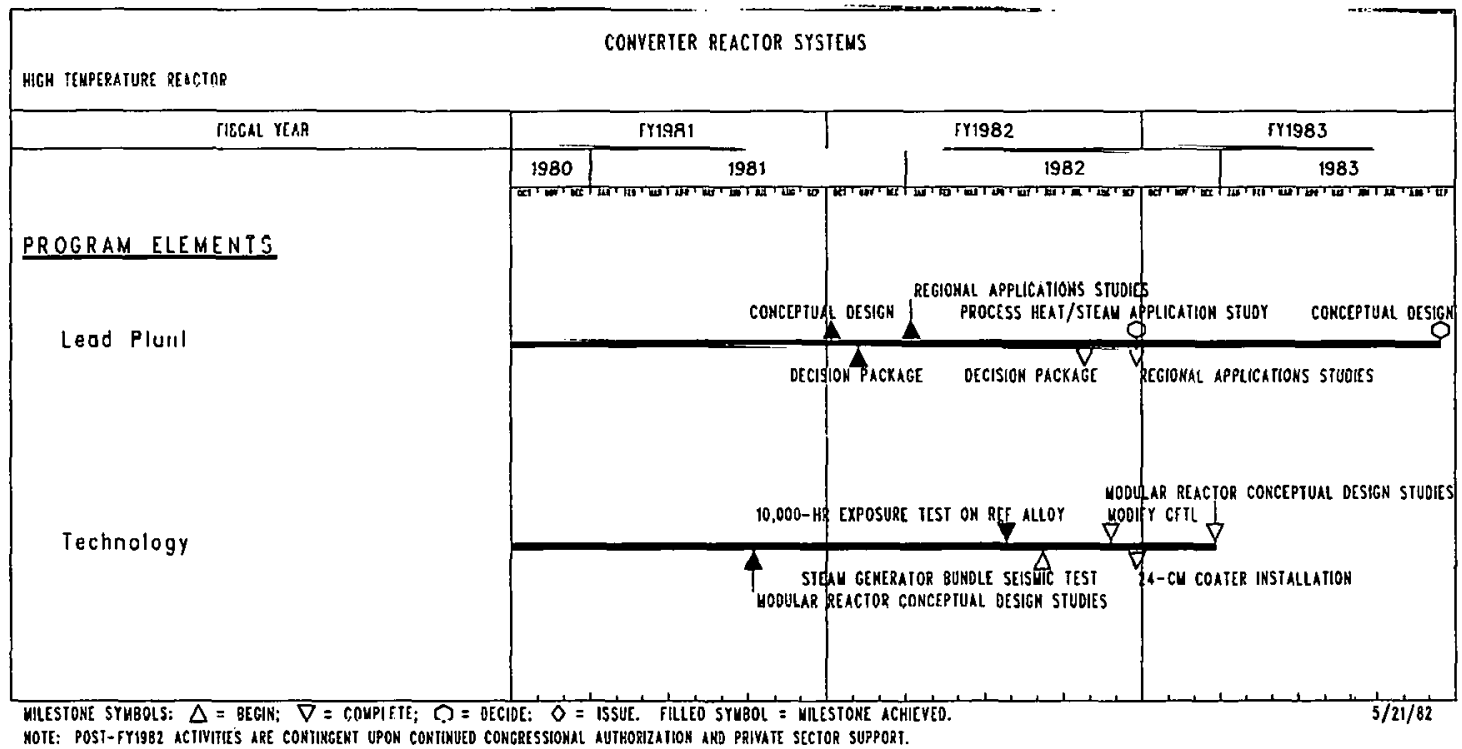




\section{B. BREEDER REACTOR SYSTEMS}

Nuclear fission using breeder reactors is capable of providing an inexhaustible energy supply. This section describes DOE's program for breeder reactor development. Programmatic descriptions are included for the Liquid Metal Fast Breeder Reactor (LMFBR) and the Water Cooled Breeder (WCB) Reactor.

\section{Overview}

Background. The potential for fission energy to provide essentially inexhaustible supplies of civilian electric power through the use of breeder reactor systems was recognized in the 1940s. Development has proceeded since that time, with the priority effort concentrated on the LMFBR concept since the 1960s. A number of experimental facilities have been constructed and operated in the United States, notably:

- the Experimental Breeder Reactor No. 2 (EBR-II), which continues to provide electricity to DOE's Idaho National Engineering Laboratory after almost 20 years of operation, and

- the Fast Flux Test Facility (FFTF), which began routine testing operation in April 1982 as a major fuel testing facility.

Abroad, LMFBR development has been carried through the demonstration plant stage in France, the UK and the USSR, and the first commercial-scale LMFBR is now under construction in France.

Objective. The overall objective of the breeder reactor program is to ensure that this long-term electricity supply source is available on a prudent time scale.

Strategy. The Federal role in the future of breeder reactors is to conduct the necessary research, development, and demonstration such that the potential benefits of the breeder can be assumed by private industry at a venture risk level that is consistent with acceptable business endeavors. The responsibility for industrialization and deployment will rest with the private sector.

Management. Figure 2 shows the delegation of responsibility for the breeder reactor systems programs. Further breakdown of these delegations are shown in similar charts in the following sections which describe the individual programs.

Funding. The following table shows the operating funding levels by program element for the FY 1981 through FY 1983 period.

BREEDER REACTOR SYSTEMS

\begin{tabular}{lrrrrr}
\hline & & \multicolumn{3}{c}{ BUDGET AUTHORITY } \\
& \multicolumn{4}{c}{ (DOLLARS IN THOUSANDS) } \\
\hline PROGRAM ELEMENT & $\begin{array}{c}\text { OBLIGATIONS } \\
\text { FY } 1981\end{array}$ & $\begin{array}{c}\text { APPROPRIATIONS } \\
\text { FY } 1982\end{array}$ & $\begin{array}{c}\text { REQUEST } \\
\text { FY 1983 }\end{array}$ & $\begin{array}{c}\text { INCREASE } \\
\text { (DECREASE) }\end{array}$ \\
\hline LIQUID METAL FAST & & & & \\
BREEDER REACTOR & 501,167 & $499,422^{\mathrm{a}}$ & 486,934 & $(12,488)$ \\
WATER COOLED BREEDER & 58,000 & $50,500^{\circ}$ & 41,800 & $(8,700)$ \\
\hline TOTAL & 559,167 & 549,922 & 528,734 & $(21,188)$ \\
\hline
\end{tabular}

a Reflects reduction of $\$ 2,200,000$ for reprogramming to Solar and Departmental Administration.

b Reflects reduction of $\$ 500,000$ for reprogramming to Solar.

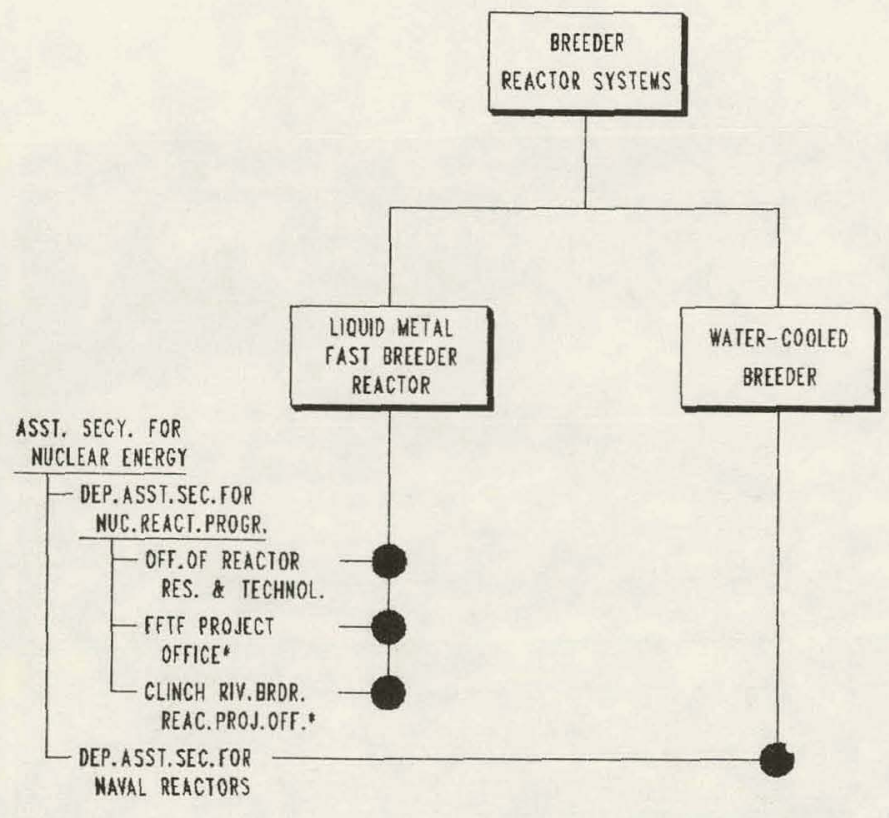

note: "Figure shows programmatic relationships onLY; PROJECT OFFICES REPORT DIRECTLY TO THEIR LOCAL OPERATIONS OFFICES.

Figure 2. Breeder Reactor Systems upper level work breakdown structure and DOE responsibility matrix.

\subsection{Liquid Metal Fast Breeder Reactor}

The liquid metal fast breeder reactor (LMFBR) is the reactor system most capable of exploiting the vast energy resources of natural uranium. Its advantage over other breeders stems primarily from the excellent heat transfer properties of the sodium coolant that enables the LMFBR to operate at high temperature without resort to pressurized systems. The practical result is a plant with high thermal efficiency-about 40 percent for an LMFBR as compared with 32 percent for light water reactors. In contrast to other high technology "inexhaustible resource" options, pilot LMFBR units are now in successful operation.

The LMFBR is a "breeder" because it produces more fissile material than it consumes. This means that it not only produces enough fuel for its own continued operation, but also generates additional fuel for other reactors. The LMFBR converts uranium-238 (a fertile material) which is not directly usable as reactor fuel into reactor grade plutonium, which is fissionable and, therefore, usable as reactor fuel. This conversion is especially significant, since the present light water cooled reactors achieve their heat energy primarily from the fission of relatively scarce uranium235 , which is present in natural uranium only to the extent 
of about 0.7 percent; more than 99.9 percent of the remainder is uranium-238. The breeder ultimately makes available 60 percent or more of the energy potential of natural uranium. The major fuel supply for breeders will be the spent fuel and depleted uranium tailings not currently being used. There is already mined and available enough fertile uranium to supply the equivalent of the nation's electricity needs for 700 years.

- Objectives. The objective of the United States LMFBR program is to industrialize the breeder.

- Description. The LMFBR Program consists of plant projects; engineering and technology efforts in reactor fuels and materials, components, physics, and safety; and the operation of test facilities. The program is focused on the construction and operation of the intermediate-sized Clinch River Breeder Reactor Plant (CRBRP). A conceptual design of a Large Developmental Plant (LDP) was previously produced. Continued planning and design efforts for a commercialscale LMFBR will continue if an international cooperative effort is concluded.

\subsection{Plant Projects}

The existing plant developmental projects are:

- Clinch River Breeder Reactor Plant; and

- Large Developmental Plant.

The CRBRP is a joint Government/industry effort to construct a 375-MWe demonstration breeder reactor powerplant at Oak Ridge, Tennessee. The LDP is a 1000-MWe LMFBR currently in the advanced conceptual design phase.

Clinch River Breeder Reactor Plant Project. Tu bring LMFBR technology to a point of acceptable commer- cial risk requires that the technology be advanced and confirmed by constructing and operating plants of increasingly larger sizes. CRBRP is the next LMFBR plant in the deliberate sequence of plants of increased size. The overall objective of the CRBRP project is lo desiyn, cuisliuct, and test the Nation's first intermediate-scale (375-MWe) LMFBR powerplant and operate the plant as part of a utility system. Its size represents a technically significant yet prudent scale up in plant technology. The CRBRP will provide important information regarding the safety, environmental, and economic potential of LMFBRs as an essentially inexhaustible, domestic energy source. An artist's conception of the plant is shown in Figure 3. Construction is planned for a site adjacent to the DOE reservation at Oak Ridge, Tennessee, where it will be operated as a part of the Tennessee Valley Authority (TVA) electrical supply network.

President Reagan in his October 8,1981 , policy statement on nuclear power stated that completion of the Clinch River plant is essential to ensure our preparedness for long-term nuclear power needs. The CRBRP project is presently authorized under Public Law 91-273, as amended. Under the subject law, Congress authorized the Department to enter into a definitive cooperative arrangement for an LMFBR plant. That cooperative arrangement, called the quadripartite contract between the Department of Energy, Project Management Corporation (PMC), Tennessee Valley Authority (TVA), and Commonwealth Edison (CE), has been in effect since 1973.

The Department of Energy's role in the CRBRP project consists of overall project management and major financial support. Government financial support to the project is applied to all elements of the project including design, development, equipment, and plant costs. DOE will pruvide all project funding in exccss of the utilities'

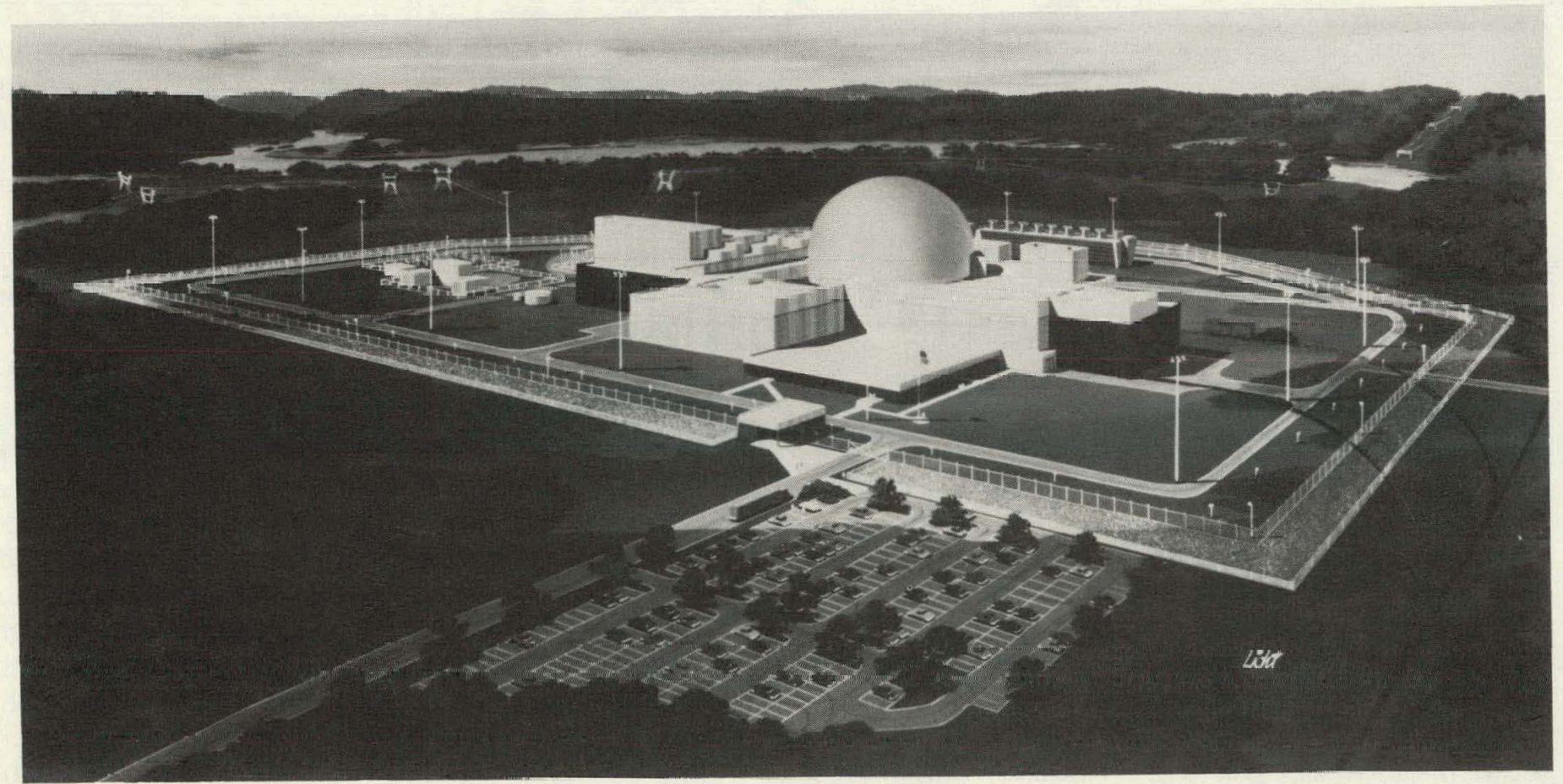


contributions of approximately $\$ 261,000,000$ and the reactor manufacturers' and vendors' contributions of approximately $\$ 10,000,000$ and the interest earned on the contribution from the utilities.

The utilities provide management and technical assistance and financial support to the CRBRP project. Commonwealth Edison of Chicago and TVA are the principal utilities that provide management and technical assistance through their participation in the activities of the PMC, a nonprofit group formed especially to represent the interests of the utility industry in the day-to-day management of the project. A second nonprofit group, the Breeder Reactor Corporation (BRC) provides senior counsel on behalf of the utility industry and keeps the public and the electric power industry informed on project matters. BRC is composed of 753 electric systems from the public, private, municipal, and cooperative sectors of the electric power industry that support the project and that have pledged contributions to the project of $\$ 261,000,000$.

The CRBRP Project is well advanced. Design is almost 90 percent completed. Approximately 60 percent of the hardware required for the plant is on order or has already been completed. The Nuclear Regulatory Commission is actively reviewing the project's license application. The Project is in a position to start site clearing and construction activities upon receipt of the required approvals from the NRC. Completion of the plant and the attainment of initial criticality is planned for the late 1980's. The plant will then be operated for a 5-year demonstration period.

Large Developmental Plant Project. DOE efforts supporting a large developmental plant are entering a new phase in which the Government will provide support and encouragement to a newly initiated utility activity to define the design, cost, schedule, and implementation plans for a developmental plant whose construction will be principally funded by the private sector. A major activity that will be undertaken in concert with the private sector is an effort to develop international participation in the project so as to minimize program costs and to allow maximum utilization of international technological advances. If satisfactory progress is achieved in FY 1982 in development of cooperative arrangements with foreign nations and the private sector, continued Government support for the planning and design of a large-scale prototype breeder in FY 1983 will be provided.

In this light, the LDP project is proceeding in FY 1982 with the advanced conceptual design, preparation of detailed cost and schedule estimates, and the definition of the research and development required to support a largescale prototype LMFBR plant. Highlights of this project during the last year include efforts to optimize the overall plant design and to reduce the estimated plant capital cost. Also, the design and research and development results of the FFTF, the Clinch River project, and the breeder base program are being incorporated into the large plant advanced conceptual design.

In FY 1983, appropriate utility criteria and plant requirements will be incorporated into the advanced conceptual design, and consolidation of the Government/utility efforts in support of the large plant will be implemented. An integral part of this consolidation effort is the evaluation of the potential benefits to the large plant of expanded foreign cooperation. Areas identified as having the potential for significant benefits will be pursued through negotiations with appropriate foreign nations. Agreements signed during FY 1982 with foreign nations will provide the mechanism under which such negotiations will be conducted. Considering inputs from the utility participants and foreign nations, the FY 1983 effort will also include advancement of the design of key systems; continuation of cost reduction optimizations; and the update of project criteria, specifications, planning schedules, and the cost estimate.

\subsection{Breeder Technology Program}

This portion of the LMFBR program has as its purpose the industrialization of the breeder. It is concentrated in areas of technology development that are within existing Federal capability but beyond the capability of the private sector. The program elements are:

- Safety;

- Component development for testing;

- Materials and structures;

- Physics; and

- Fuels and materials.

Safety. This program is directed toward public safety considerations associated with LMFBRs. The mission of the program is to provide an adequate data base for assessment of risk to the public from reactor accidents, and to enhance the safety-related design of LMFBRs. Program effort falls into two main areas--prevention of accidents and mitigation of accident consequences. It will provide a technology base fully responsive to safety considerations in the design, evaluation, licensing, public acceptance, and economic optimization of LMFBRs for electric power generation.

A major reactor accident cannot take place unless a sequence of failures occurs within the reactor system. The safety goal depends upon developing technology in four generic and integrated segments (Lines of Assurance), each of which relates to a sequential barrier preventing accident progression, thus preventing release of any significant amount of radioactivity to the environment. These are described as follows:

\begin{tabular}{|c|c|c|c|}
\hline $\begin{array}{l}\text { Major events in } \\
\text { core-disruptive } \\
\text { accidents }\end{array}$ & $\begin{array}{l}\text { Line of } \\
\text { Assurance } \\
\text { (LOA) }\end{array}$ & $\begin{array}{l}\text { Barrier to } \\
\text { progression }\end{array}$ & $\begin{array}{l}\text { Example of } \\
\text { threat to } \\
\text { barrier }\end{array}$ \\
\hline Initiating fault & $\begin{array}{l}\text { LOA-1: Prevent } \\
\text { accidents }\end{array}$ & Fuel cladding & Fuel melting \\
\hline $\begin{array}{l}\text { Initiation of fuel } \\
\text { melting }\end{array}$ & $\begin{array}{l}\text { LOA-2: Limit } \\
\text { core damage }\end{array}$ & $\begin{array}{l}\text { Subassem- } \\
\text { bly boundary }\end{array}$ & $\begin{array}{l}\text { Loss of } \\
\text { coolable core } \\
\text { geometry }\end{array}$ \\
\hline $\begin{array}{l}\text { Whole-core } \\
\text { melling }\end{array}$ & $\begin{array}{l}\text { LOA-3: } \\
\text { Madirlain } \\
\text { containment } \\
\text { integrity }\end{array}$ & $\begin{array}{l}\text { Primary and } \\
\text { securidary } \\
\text { containment } \\
\text { systems }\end{array}$ & $\begin{array}{l}\text { Energy and } \\
\text { pressure } \\
\text { sources from } \\
\text { core meltdown }\end{array}$ \\
\hline $\begin{array}{l}\text { Radioactivity } \\
\text { release }\end{array}$ & $\begin{array}{l}\text { LOA-4: } \\
\text { Attenuate } \\
\text { radiological } \\
\text { consequences }\end{array}$ & $\begin{array}{l}\text { Engineered } \\
\text { systems and } \\
\text { inherent } \\
\text { mechanisms }\end{array}$ & $\begin{array}{l}\text { Unantici- } \\
\text { pated events }\end{array}$ \\
\hline
\end{tabular}


Conservatism and quality assurance in the design, construction, and operation of nuclear powerplant components and systems are major contributors to prevention of accidents. Thus, Breeder Technology elements other than Safety, i.e., Components, Materials and Structures, Physics, and Fuels and Materials, play a significant role in accident prevention. The extensive in-reactor performance testing of reactor fuel and the zero-power reactor core physics experiments are representative examples of accident prevention R\&D carried out by elements other than Safety. The Safety element focuses, therefore, on accident prevention (LOA-1) activities not supported by other Breeder Technology elements.

Safety R\&D in LOA-1 involves demonstration of reactor system reliability in preventing the occurrence of accidental events requiring prompt reactor shutdown, and demonstration of highly reliable reactor shutdown and shutdown heat removal should such events occur. An example of work in LOA-1 is the evaluation of plant status and maintenance control system operational experience in FFTF. This system represents a state-of-the-art advancement in reactor plant man-machine interface technology.

LOA-2 R\&D aims to demonstrate that faults in the shutdown and shutdown heat removal systems, and local faults within the core itself, can be accommodated with only limited damage to the core. An example of LOA-2 work is the post-test examination and analysis of a failed fuel blockage test previously conducted in the Sodium Loop Safety Facility.

Safety R\&D in LOA-3 and LOA-4 covers investigation of the potential of hypothetical core-disruptive accidents (HCDA's) to damage reactor and containment structures, development of engineered systems to reduce potential releases of radioactive material from containment, and studies of the inherent attenuation of airborne radioactive materials. Current LOA-3 and LOA-4 work includes Transient Reactor Test Facility (TREAT) tests of preirradiated LMFBR fuel pins under simulated accident scenarios, validation of computer codes that predict accident energetics and describe the behavior of containment structure under accident conditions, development of a recommended approach to accommodation within the reactor vessel of debris from core melting, and large-scale aerosol behavior tests in the HEDL Containment Systems Test Facility, with a supporting computer code validation study.

Components. The Components program encompasses development of the technology required for critical components of LMFBR heat transport systems and auxiliary systems, as well as the development of the data, processes, and analytical methods needed to support the design, fabrication, and operation of safe and reliable components and systems. Experience with breeder reactor plants in this country (EBR-II and Fermi) and abroad (the British Prototype Fast Reactor, French Phenix, Russian $\mathrm{BN}-350$, and $\mathrm{BN}-600$ ) has shown that the heat transport components have been the major source of plant operational deficiencies, resulting in greatly reduced plant reliability and availability. Therefore, the program stresses the development of essential heat transport components, which involve unproven concepts such as sodium-to-water steam generators and main coolant pumps.

The component development program has been structured to provide the technology for reliable and economic equipment through the design, fabrication, and testing of equipment models and by providing the supporting technology needed for component and system design and fabrication. Important data and information from design, fabrication, test, and operation of components for EBR-II, FFTF, and CRBRP are continuously utilized in the program. Component vendors design and fabricate model components and perform the concept-dependent supporting development. Tests and generic-type development are conducted by the national and engineering laboratories and the reactor manufacturers.

In the international LMFBR community, it is recognized that the sodium-to-water steam generator is the most complex and demanding component from englneering design and system relıabılıty viewpoints. The U.S. steam generator program includes the development of two different steam generator designs - a singlewall, helically coiled tube concept by the Babcock and Wilcox Company, Barberton, Ohio, and a double-wall straight tube concept by Westinghouse Electric Corporation's Nuclear Components Division, Pensacola, Florida. For each concept, testing of critical component features, small model testing, and manufacturing development are followed by fabrication and delivery for testing of a $70-\mathrm{MWt}$ model in the Sodium Components Test Installation (SCTI) at the Energy Technology Engineering Center (ETEC), Canoga Park, California. In addition, development and testing of leak detection systems for steam generators is being conducted to assure the capability of rapidly detecting annd terminating a leak before it develops into a large leak.

In the U.S. pump development program, work is underway at the Westınghouse Electric Corporation's Electromechanical Division, Cheswick, Pennsylvania, for development of a two-stage primary pump; at Borg Warner Corporation's Byron Jackson Pump Division, Carson, California, for development of a single stage intermediate pump; and at Rockwell International's Energy Systems Group, Canoga Park, California, for the development of an inducer primary pump. Test units of the two-stage primary pump and single stage intermediate pump are being fabricated for testing in the ETEC Sodium Pump Test Facility (SPTF). To evaluate the suitability of the inducer for use with sodium, an inducer pumping element was installed on a spare FFTF primary pump and tested in the SPTF in 1981 , and sodium and water tests of small models of the pump are on test at ETEC in 1982.

In the supporting development program area, experiments and analyses are conducted to develop validated design and analysis procedures to predict and minimize such potentially detrimental conditions as flow induced vibration, flow maldistribution, and stratification in components and systems.

Materials and Structures. The Materials and Structures program encompasses the development and transfer to designers and manufacturers experimentally verified 
structural design and materials technologies aimed at assuring the economic, safe, and reliable performance of LMFBR components and systems. The program will provide technology to assure with high probability that LMFBR components and systems will be free from significant structural failures during their design lifetimes. This includes development of design methods and criteria, materials property data, and procedures that are verified and practical to apply.

The technology areas covered are those for high-temperature structural design, seismic design, mechanical properties design data, fabrication, nondestructive testing, tribology (friction, wear, and self-welding), advanced structural alloys, materials properties documentation, and coolant technology.

The output of the program is used in specific LMFBR projects such as CRBRP as well as in other development programs such as components and safety. The overall strategy includes: 1) providing timely guidance to design teams, 2) performing all necessary R\&D in support of the ultimate design choices, 3) maximizing use of information derived from previous generic and specific research and development (EBR-II, FFTF, and CRBRP), and 4) maximizing the use of information derived from foreign exchange arrangements.

The products of the program are technical guidelines, design rules, data, and documentation. Thus, the deliverables include reports, guideline documents, contributions to NE (RDT) standards, contributions to consensus standards (e.g., ASME-BPV Codes and ASTM Standards), and the Nuclear Systems Material Handbook, which is a repository for LMFBR material related to design data.

Physics. The Physics program is directed toward the development of the fast reactor neutronics capabilities required to provide reliable design data, accurate safety analyses, well-qualified fuel management, and reactor start up, testing and operating procedures. The Physics program provides experimental determinations of core and shield properties, nuclear data measurements and evaluations, and development of computational methods for accurately and economically predicting core performance, shield effectiveness, and safety parameters. Program activities will result in significant improvements in core design accuracy and significant savings in reactor construction and operating data by development of the most favorable design options and fuel cycles for FFTF, CRBRP, and longer-term interests. Emphasis in the near term is placed on analysis of the FFTF neutronic performance and changes due to core reload and test requirements. A program of mockup, benchmark, and interpretive critical experiments establishes the neutronic characteristics of those LMFBR cores selected for first-of-a-kind reactors. Much of the experimental work is carried out at the ZPPR critical facilities. Selected shielding experiments are performed at the tower shielding facility. Neutron interaction and scattering properties of reactor materials are measured at the FNG and ORELA facilities over a wide range of energies and angles to enable reliable core design calculations. Properties of fission products such as decay heating, neutron absorption, and neutron emission are determined for many required reactor design applications. State-of-the-art experimental and analytical physics capabilities are applied to improve understanding of reactor fuel burnup.

Fuels and Materials. The Fuels and Materials program encompasses the development of fuel, blanket, and control core components for LMFBRs; the development of materials for use in these components; and the development of equipment, processes, and facilities to fabricate fuel and assure a supply of such fuels for program breeder reactors.

The core components and materials program comprises two parallel activities: (1) conduct surveillance of the FFTF core for confirmation of previous development work on reference FFTF fuel-system materials (i.e., uranium/plutonium oxide fuel and Type-316 stainless steel cladding and ducts) to validate its performance, the calculations, codes and design methodologies that were used in its design, to establish performance limits, to provide confidence for the predicted performace of the CRBRP core which is similar to FFTF, to support the safe and reliable operations of FFTF as a test reactor, and (2) conduct sufficient investigations on advanced fuels, blankets, and absorber concepts to narrow the options to the point where prime systems can be selected and developed. The program depends heavily on irradiation testing of fuels and materials conducted in the EBR-II and to be conducted in the FFTF. Significant aspects of the irradiations program in EBR-II have included: (a) carrying advanced fuels tests to and beyond goal burnups to identify ultimate performance limits, (b) continuing irradiations of advanced cladding and duct materials to high exposures, and (c) performing Run-Beyond Clad-Breach (RBCB) tests. Key aspects of the irradiations to be conducted in FFTF include: (a) qualifying FFTF driver fuels, (b) testing candidate advanced cladding and duct materials, and (c) testing fullscale advanced fuels and blanket pins. These experiments will lead to tests of full-scale assemblies of prime candidate advanced fuels and blanket concepts, which will be followed by partial core loadings of such assemblies for qualification of safe and reliable operation.

The program for qualifying the performance of replaceable core components for FFTF will be conducted principally within the framework of a systematic driver fuel and absorber evaluation plan involving periodic removal of reference driver fuel assemblies for thorough post-irradiation examination. This evaluation will extend through the first 3 years of FFTF operation. Performance surveillance will continue during subsequent operation, but on a more routine basis.

The advanced core components effort involves the development of long-lived, highly reliable components that will enhance plant efficiency, performance, and reliability. Major emphasis is placed on obtaining a comprehensive base of component performance information, derived for a wide variety of design options and a broad range of operating conditions. The experimental portion of this activity consists of a series of tests of pin and assembly variables 
that will provide a broad coverage of fuel parameters, advanced cladding and duct materials, pin and assembly design, and analytical capabilities.

Fuel fabrication process development efforts focus on the Secure Automated Fabrication (SAF) program. Major emphasis is directed toward applying SAF technology to the production of fuel for CRBRP and FFTF. The program incorporates advanced automation and remote processing technologies that will reduce personnel exposure, reduce costs, enhance special nuclear materials safeguards and accountability, minimize personnel access to materials, increase productivity and quality, and incorporate scrap and waste handling procedures; as well as the process control and safety systems required to meet the program's goals. The initial application of SAF technology will be a fuels fabrication line (SAF line) (see Figure 4), which will be installed in the Fuels and Materials Examination Facility (FMFF) under construction at Richland, Washington.

\subsection{Test Facilities}

Test facilities are an essential part of the LMFBR program in that they provide the capability to test systems and components developed under the breeder technology program, as well as prototypes and models of components to be incorporated into plant projects. Through operation of irradiation facilities such as the FFTF (Figure 5) and EBRII (Figure 6), and operation of large non-nuclear sodiurn facilities, plant performance information on operation and maintenance is also generated to support plant projects.

Emphasis is added to the need for test facilities by the increase in size being considered for plants beyond CRBRP. The size extrapolation from FFTF components by a factor of seven or more and for CRBRP components by a factor of nearly three will require adequate testing to identify and minimize risks.

In keeping with the national interest, safeguards and security measures at all facilities involved with special nuclear materials (SNM) must be maintained and upgraded as necessary to assure adequate protection of SNM against diversion, theft, or terrorist activity.

Major test facilities covered by this element are located at the following Government-owned sites: Argonne National Laboratory (ANL), Energy Technology Engineering Center (ETEC), and Hanford Engineering Development Laboratory (HEDL). Existing test facilities are operated and maintained, modifications to existing facilities are made, and new facilities are provided in support of the plant projects and breeder lechmology elements of the LMFBR program in accordance with technical requirements, priorities, and schedular needs identitied under those elements, consistent with safe, efficient operation and acquisition practices.

lable 1 lists the elements of the LMFBR prograrr, the major test facilities supporting each element, and the facility locations. Those facilities, which support more than one program element, are listed several times.

Implementation/Strategy. All the other advanced nuclear nations--France, Great Britain, West Germany, U.S.S.R., and Japan--are proceeding towards the commercial breeder. For example, France expects to have a 1200-MWe breeder on line in 1984. The Reagan Administration also supports the orderly development of the breeder, but in such a manner as to be cost effective from a Federal investment point of view and to allow the private sector to determine when to commercialize this reactor

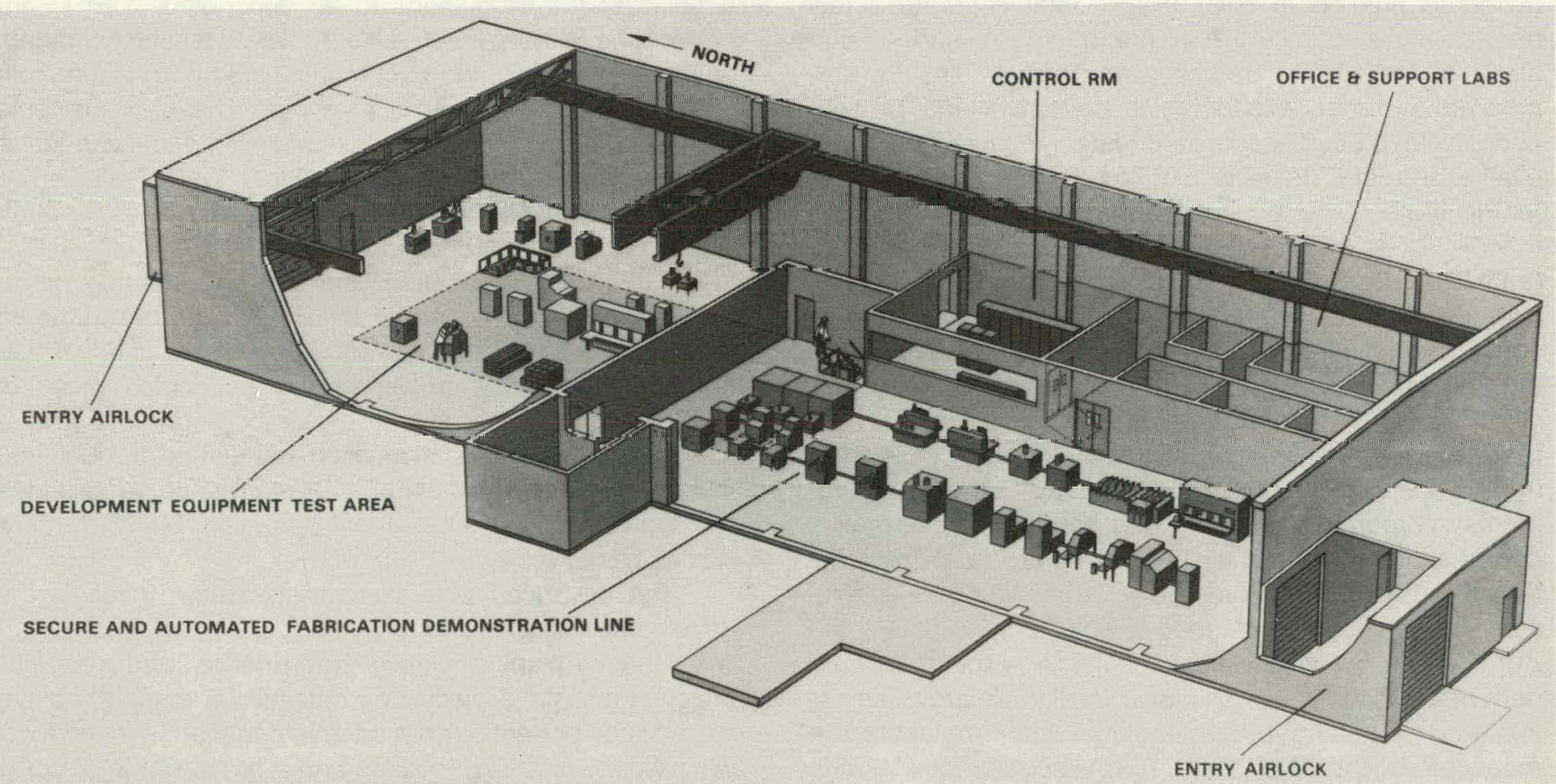




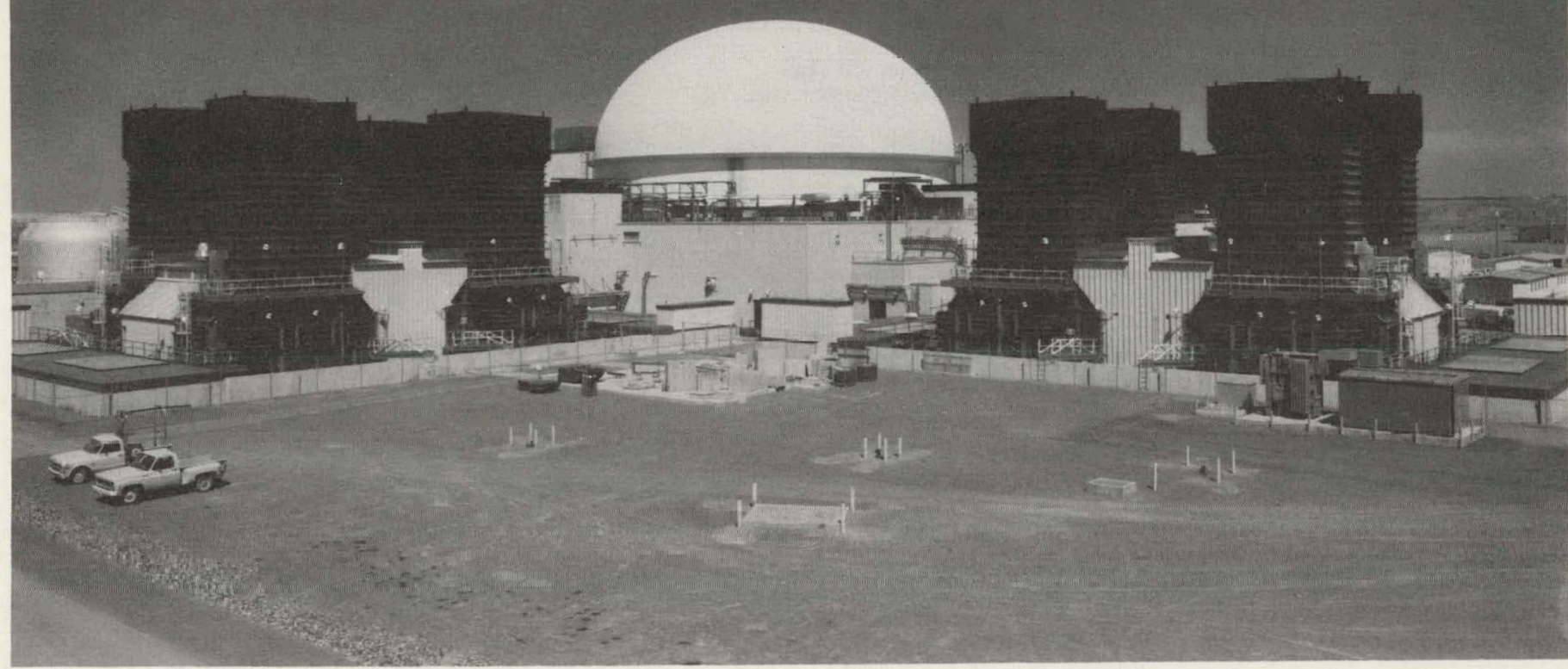

Figure 5. Fast Flux Test Facility at HEDL

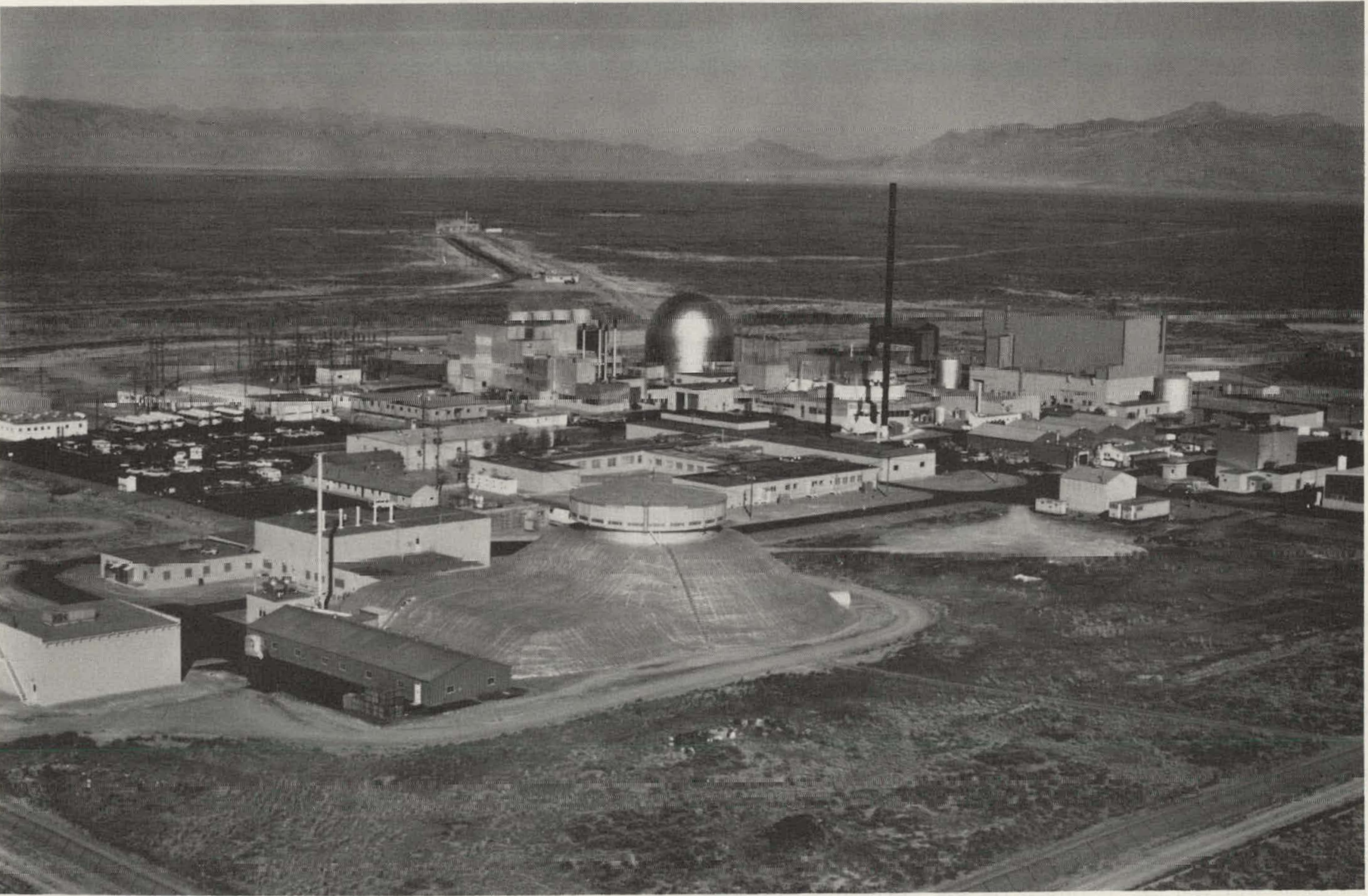

Figure 6. ANL-West Site including EBR-II, ZPPR, HFEF, and TREAT 
Table 1

\section{Major Test Facilities in Support of LMFBR Program Elements}

\begin{tabular}{|c|c|}
\hline Program Element & Test Facility \\
\hline Plant Projects & $\begin{array}{l}\text { Fast Flux Test Facility (FFTF) } \\
\text { Maintenance and Storage Facility (MASF) } \\
\text { Fuel Storage Facility (FSF) } \\
\text { Experimental Breeder Reactor No. II (EBR-II) } \\
\text { Sodium Pump Test Facility (SPTF) } \\
\text { Sodium Component Test Installation (SCTI) }\end{array}$ \\
\hline \multicolumn{2}{|l|}{ Breeder Technology } \\
\hline Safety & $\begin{array}{l}\text { Fast Flux Test Facility (FFTF) } \\
\text { Experimental Breeder Reactor No. II (EBR-II) } \\
\text { Transient Reactor Test Facility (TREAT) } \\
\text { Hot Fuel Examination Facility (HFEF) }\end{array}$ \\
\hline Components & $\begin{array}{l}\text { Fast Flux Test Facility (FFTF) } \\
\text { Experimental Breeder Reactor No. II (EBR-II) } \\
\text { Sodium Components Test Installation (SCTI) } \\
\text { Sodium Pump Test Facility (SPTF) } \\
\text { Components Handling and Cleaning Facility (CHCF) } \\
\text { Simall Cum InuI IEII Tesl Luup (3CTL) } \\
\text { Static Sodium Test Facilities (SSTF) }\end{array}$ \\
\hline Materials and Structures & $\begin{array}{l}\text { Fast Flux Test Facility (FFIF) } \\
\text { Expenin Ienlal Dieeder Meactor No. II (EBR II) }\end{array}$ \\
\hline Physics & $\begin{array}{l}\text { Fast Flux Test Facility (FFTF) } \\
\text { Zeru Power Plutonium Reactor (ZPPR) }\end{array}$ \\
\hline Fuels and Materials & $\begin{array}{l}\text { Fast Flux Test Facility (FFTF) } \\
\text { Experimental Breeder Reactor No. II (EBR-II) } \\
\text { Hot Fuel Examination Facility (HFEF) } \\
\text { Fuels and Materials Examination Facility (FMEF) } \\
\text { Transient Reactor Test Facility (TREAT) }\end{array}$ \\
\hline
\end{tabular}

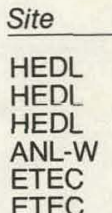

ETEC

HEDL

ANL-W

ANL-W

ANL-W

HEDL

ANL-W

ETEC

ETEC

ETEC

FTFr:

ETEC

IICDL

ANI -W

HEDL

ANI -W

HEDL

ANL-W

ANL-W

HEDL

ANL-W system. It is in this context that the liquid metal fast breeder reactor strategy has been developed.

It is important to note that this program strategy does not plan on Federal funding for an eventual commercialsize plant. Rather, this strategy sees the Federal role ending when the technology base is judged to be sufficiently developed to permit the private sector to assume responsibility for LMFBR industrialization and commercial deployment.

The technologies needed for development of the LMFBR will be the end result of a planned sequence of development breeder and other reactor facilities that began with Experimental Breeder Reactor I (the world's first source of nuclear-generated electric power); followed by the 20-MWe Experimental Breeder Reactor II; the 65.9MWe Enrico Fermi Atomic Power Plant (the first LMFBR plant to supply electricity to a commercial utility test grid); the 133-MWe (equivalent) Fast Flux Test Facility, which is now operating and will be used principally as a fuels and materials testing facility; and the 375-MWe Clinch River Breeder Reactor Plant. In addition to major zero-power reactors for determining the configurations and nuclear characteristics of LMFBR cores and blankets, the breeder program was also supported by the 20-MWt Southwest Experimental Fast Oxide Reactor, which was operated essentially for physics experiments and has since been decommissioned.

To attain the objective of developing the technology to a point where the risk is acceptable to the private sector, vigorous effort will be resumed on the construction and operation of the CRBRP and a strong base technology program will be maintained. The Nuclear Regulatory Commission's environmental and safety reviews of the CRBRP project have been resumed and are currently proceeding. It is expected that the NRC staff will complete its environmental review this fiscal year and complete its safety review in Fiscal Year 1983. These reviews will be followed by public hearings with the expectation that a construction permit will be issued in mid-1984.

The CRBRP will be supported by a base research and development program that provides the necessary engineering and satety analysis, along with the technology improvements required for plant scale-up. I he combination of the base research and development program and the CRBRP project will furnish the driving force to develop the engineering infrastructure and the technology required for the private sector to pursue LMFBR commercialization.

For the LDP, the next step beyond CRBRP, DOE is now attempting to develop the framework for beneficial cooperation in a large LMFBR plant project with the private sector and with various foreign countries. Progress in this area to date is very encouraging. If broad cooperation can be successfully achieved in a large plant project, the risks and cusls of proceediriy wilh the development of the breeder could be significantly reduced. Cooperative international arrangements also offer the potential for developing a sound basis for institutional fuel cycle arrangements needed to support the breeder. 1981 were:

Accomplishments. Major accomplishments in FY

- The Fast Flux Test Facility reactor achieved full design power operation of $400 \mathrm{MWt}$ (December 21, 1980).

- The Conceptual Design Study of a 1,000 MWe LMFBR was submitted to Congress (March 1981).

- Design of the Clinch River Breeder Reactor Plant was 86 percent complete. 
- Completed ZPPR engineering mockup critical experiments to validate CRBRP design and licensing analyses.

Major accomplishments planned for FY 1982 include:

- Complete Sodium Pump Test Facility upgrade for testing CRBRP double suction pump.

- Start routine FFTF reactor fuels and materials test operations.

- Complete installation of CRBRP steam generator and pump prototypes in ETEC facilities.

- Completion of the advanced conceptual and preliminary designs at the Secure Automated Fabrication (SAF) Line.

- Ten tests of fuel failure and failure propagation were conducted in the TREAT test reactor, and preparations for the later conduct of seven tests were completed.

The major accomplishments expected in FY 1983 include:
- Complete the fabrication of the single-wall steam generator model at Babcock and Wilcox and the two stage primary pump test unit at WEMD.

- Complete testing of the CRBRP prototype hockey stick steam generator and prototype double suction pump at ETEC.

- Continued routine operation of FFTF.

- Complete preparations for sodium natural convection testing in THORS facility at ORNL.

- Receive Limited Work Authorization from the Nuclear Regulatory Commission for CRBRP.

- Continue large-scale aerosol behavior tests in the Containment Systems Test Facilty to support computer code validation activity.

Resources. The following table shows the operating funding levels by program element for the FY 1981 through FY 1983 period.

LIQUID METAL FAST BREEDER REACTOR

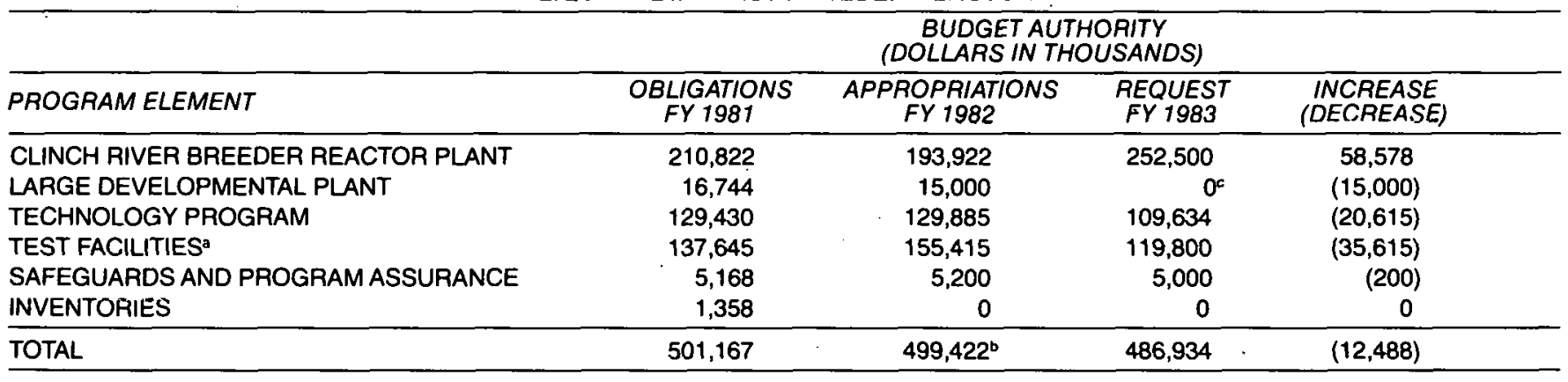

a Includes operation of the Fast Flux Test Facility and Experimental Breeder Reactor II.

${ }^{b}$ Reflects reduction of $\$ 2,200,000$ for reprogramming to Solar and Departmental Administration.

c Up to $\$ 15,000,000$ will be provided for the planning and design of a large-scale prototype breeder if an international cooperative arrangement is established. 


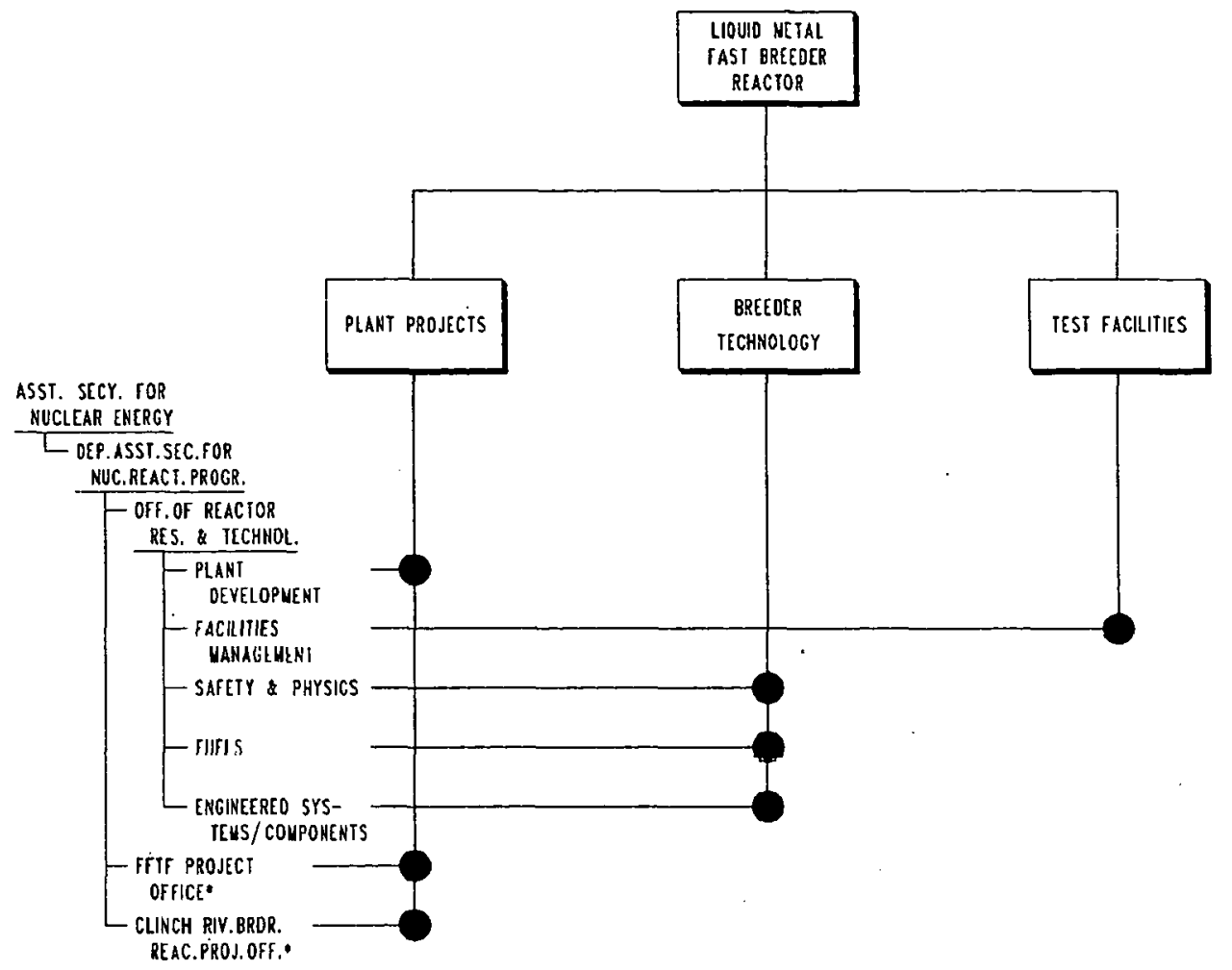

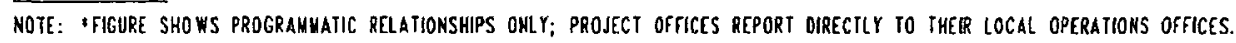

Figure 7. LMFBR program work breakdown structure and DOE responsibility matrix.

Milestones. Major milestones for the LMFBR program are given in the following chart.

BREEDER REACTOR SYSTEMS

LIQUID METAL FAST BREEDER REACTOR

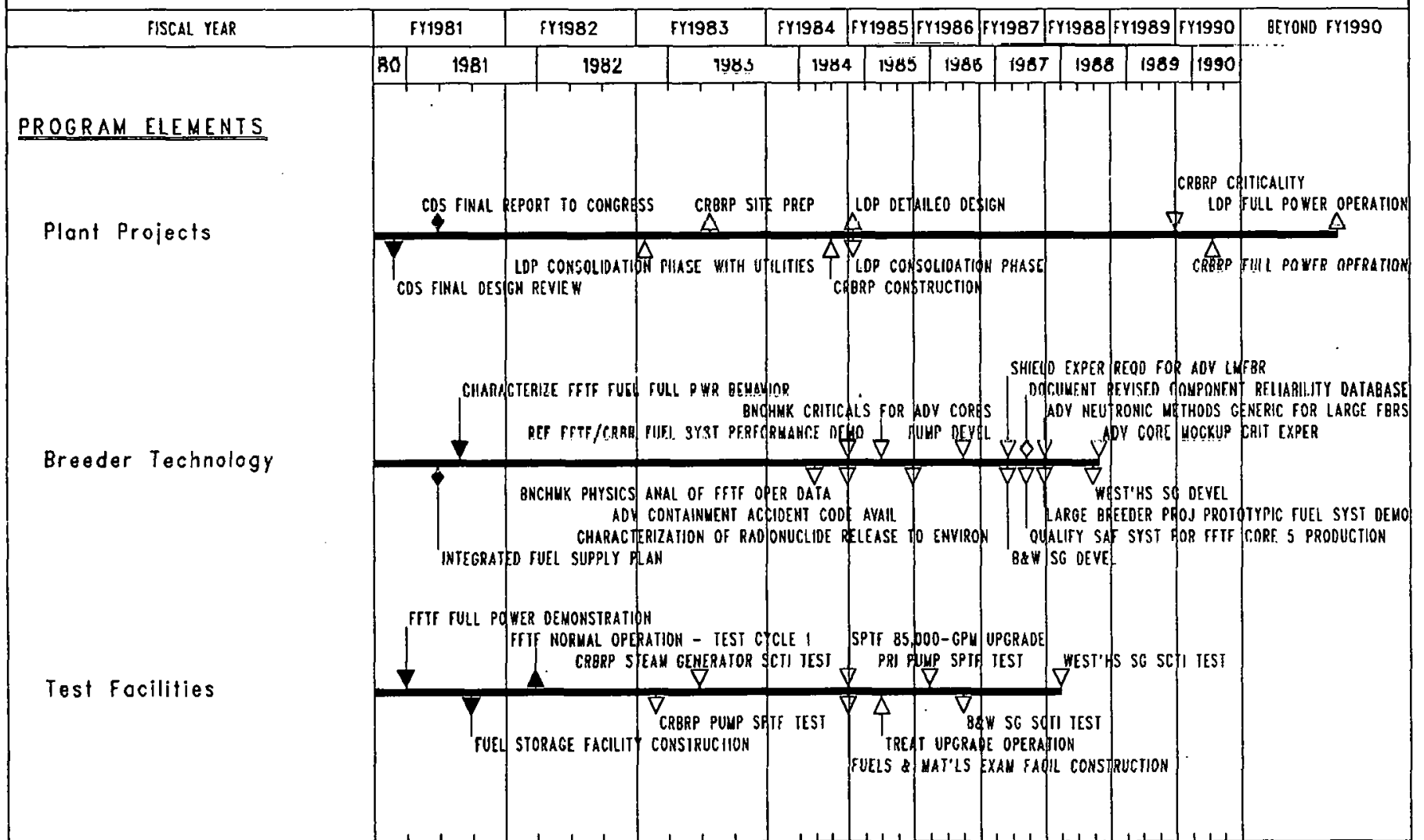

VILESTOHE SYMSOLS: $\Delta=$ BEGIN; $\nabla=$ COYPLETE; $O=$ DECIDE; $\theta=1$ ISSUE. FILLEO SYMBOL $=$ MHLESTONE ACHILYEO. 


\section{Water Cooled Breeder Reactor}

In the early 1960s, the Knolls and Bettis Laboratories under the direction of the Naval Reactors Division, U.S. Atomic Energy Commission (now DOE), determined that it might be possible to develop a practical self-sustaining breeder cooled with ordinary (light) water and fueled with uranium-233 and thorium.

Since light water reactor technology has been demonstrated to be practical in over 25 years of experience, the principal development necessary is the breeder core itself, permitting developmental efforts to concentrate on breeder core technology. Such a breeder would have the advantage of using the well-established technology of light water reactors, which is the basis of most of the present commercial nuclear power industry, and could therefore be developed without the uncertainties and cost of developing a new kind of powerplant. This early work led to the establishment of the Light Water Breeder Reactor (LWBR) program in 1965.

Objectives. The overall objective of the Water Cooled Breeder (WCB) Program is to develop technology for significantly improving the efficiency of nuclear fuel resource utilization by water cooled reactors used for electrical power generation. The WCB program in 1983 will be divided into two elements:

- Shippingport Atornic Power Station (SAPS), and

- Light Water Breeder Reactor (LWBR).

The Shippingport Atomic Power Station program objective is to advance pressurized water reactor technology through testing of advanced reactor concepts. The Light Water Breeder Reactor (LWBR) program objective is to accomplish the following: prove that breeding can be achieved in a light water nuclear reactor using the uranium$233 /$ thorium fuel system; confirm a practical way to use thorium, a plentiful source of fuel for which there has been no major energy-related use; show the feasibility of installing prebreeder and breeder cores of the LWBR type in existing and future pressurized water reactor plants using existing types of plant components and systems; and make the technology developed under the program available to commercial industry. Another technical benefit of this program is the significant improvement in the efficiency of using nuclear fuel resources that is expected to be realized from LWBR technology.

Description. The concept being demonstrated by the WCB program is a self-sustaining breeder reactor, cooled and moderated with ordinary (light) water and fueled with uranium-233 and thorium. Successful confirmation of breeding in the Shippingport Light Water Breeder Reactor core will provide the basic technology which would make available for power production about 50 percent of the energy in the nation's thorium reserves, a source of energy many times greater than the known fossil fuel reserves. This concept is the only known approach using the proven technology of the light water reactor system for increasing fuel utilization efficiency significantly beyond the approximately 1 percent achievable with present types of light water thermal reactors.
Implementation/Strategy. In October 1982, the Shippingport plant will cease routine power operation with the Light Water Breeder Reactor core and will begin end-of-life testing followed by reactor defueling. Completion of this effort will take approximately 2 years. The end-of-life testing includes core physics and engineering tests to characterize the physics and engineering properties of the LWBR core and to provide data to use as a reference point in the end-of-life examination at the Naval Reactors Expanded Core Facility (ECF). The Shippingport plant will continue to be maintained for the period necessary to complete defueling activities. Upon completion, the Shippingport Atomic Power Station will be turned over to the DOE Office of Waste Management for decommissioning activities.

The LWBR core spent fuel modules will be shipped to the ECF for a detailed core examination to verify core performance. Core examination is expected to take about 4 years. Overall, the remaining work is expected to take about 5 years.

Accomplishments (Past, Present, Future). The Shippingport Atomic Power Station, 25 miles northwest of Pittsburgh, Pennsylvania, was the first large-scale central station nuclear powerplant in the United States and the first plant of such size (initial operation $60 \mathrm{MWe}$ net) in the world operated solely to produce electric power. The project was started in 1953 by the U.S. Atomic Energy Commission (now DOE) to confirm the practical application of nuclear power for commercial purposes. Initial criticality of the first Shippingport reactor core was achieved December 2,1957 . Operation of the Shippingport plant with pressurized water reactor cores has provided much of the technology for designing and operating commercial central station nuclear powerplants now in use.

The Shippingport plant is now operating with its third core, the LWBR core. Confirmation that breeding occurred in this core will establish the basic technology that could make available for power production the energy in the nation's thorium reserves. Installation of the LWBR core required minimal modifications to the existing Shippingport plant. The startup and acceptance test program for the LWBR core was completed, and the plant was released for routine operation to supply power to the Duquesne Light Company distribution system on December 2, 1977. The LWBR core at Shippingport has completed 4-1/2 years of operation, accumulating more than 25,900 effective full power hours.

Since start-up, the LWBR core has operated successfully in both sustained operations at high power and periodic swing-load operations during which reactor power has been varied as would be required to meet power load demands. As of late August 1980, the core had accumulated more than the design objective of 18,000 effective full power hours and provided valuable test data, not only on the useful life and performance of the core, but also on the long-term performance of all aspects of light water reactors, their systems and components.

Following completion of core operation, the LWBR core fuel assemblies will be removed from the Shipping- 
port reactor vessel and the spent fuel will be shipped to the Naval Reactors Facility in Idaho for a detailed core examination to verify core performance including breeding characteristics. After having produced power well beyond design life, the expended core is expected to contain more than 1 percent more fissile fuel material than the initial loading.

The Argonne National Laboratory, under the Division of Nuclear Power Development, will provide chemical dissolution and analysis services for assaying LWBR spent fuel in support of the assessment of LWBR core breeding performance.

Under the Advanced Water Breeder Applications program, technical problems have been explored and technical information developed and disseminated through published technical reports. This effort ends at the end of FY 1982.

Resources. The following table shows the operating funding levels for the WCB program by program element for the FY 1981 to $F Y 1983$ period:

\begin{tabular}{|c|c|c|c|c|}
\hline \multirow[b]{2}{*}{ PROGRAM ELEMENTS } & \multicolumn{3}{|c|}{$\begin{array}{c}\text { BUDGET AUTHORITY } \\
\text { (DOLLARS IN THOUSANDS) }\end{array}$} & \multirow[b]{2}{*}{$\begin{array}{c}\text { INCREASE } \\
\text { (DECREASE) }\end{array}$} \\
\hline & $\begin{array}{l}\text { OBLIGATIONS } \\
\text { FY } 1981\end{array}$ & $\begin{array}{c}\text { APPROPRIATIONS } \\
\text { FY 1982. }\end{array}$ & $\begin{array}{l}\text { REQUEST } \\
\text { FY } 1983 \\
\end{array}$ & \\
\hline
\end{tabular}

\section{SPECIAL NUCLEAR EVALUATIONS AND SYSTEMS}

This section describes two diverse program elements that deal with specialized applications of nuclear energy technology. These elements take the form of applied research in the following two areas:

- Space and Terrestrial Applications

- Advanced Technology and Systems Assessment

The research done in these areas is designed to promote the use of nuclear power for specialized applications in the most economic, safe, and productive ways possible.

\section{Overview}

Background. The two programs described in this section deal with specialized areas of applied nuclear technology research and development. These activities have provided various user agencies with solutions to their special power needs by supplying specialized nuclear powered energy sources. Also, studies have been made to determine the most economic and productive ways to use nuclear power commercially.

Objectives. The principal objectives of this program area are:

- Conduct research and development activities to provide specialized nuclear power systems for use in individual user applications, such as required by NASA for the space program.

- Conduct economic, technical, and commercial feasibility evaluations for the development and deployment of conventional, advanced, and specialized nuclear systems.

Strategy. The broader-based efforts of previous years have been narrowed in scope so that funding support in FY 1983 has been requested for only one program:
- A program to advance the application of nuclear systems for space exploration and specialized terrestrial applications.

Management. The DOE Headquarters organizations responsible for directing these programs are shown in the upper level WBS/DOE responsibility matrix in Figure 8.

Funding. The table on the following page shows the operating funding during FY 1981 through FY 1983.

\section{Space and Terrestrial Applications}

The unique characteristics of nuclear-powered electric generators-their compact size, light weight, and long life-enable operation of the sensing, analytical and communication systems of spacecraft, satellites, and other remotely located devices for long time periods without relying on external sources of energy. As a result of research and development, environmentally acceptable, operationally safe, and technically qualified nuclear energy systems have been delivered to Federal user agencies for earth-

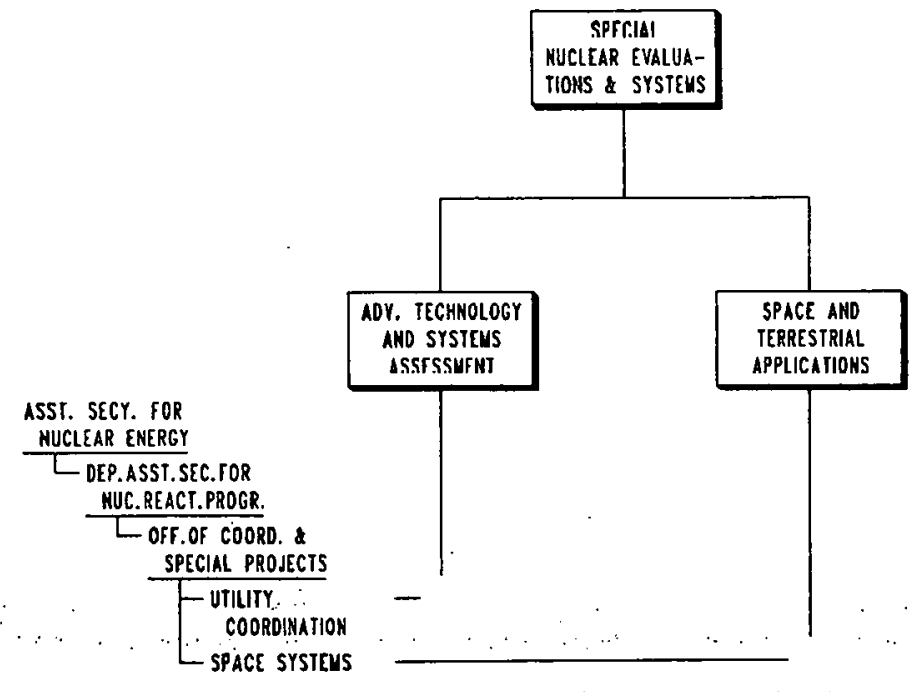

Figure 8. Special Nuclear Evaluations and Systems upper level work breakdown structure and DOE responsibility matrix. 
SPECIAL NUCLEAR EVALUATIONS AND SYSTEMS

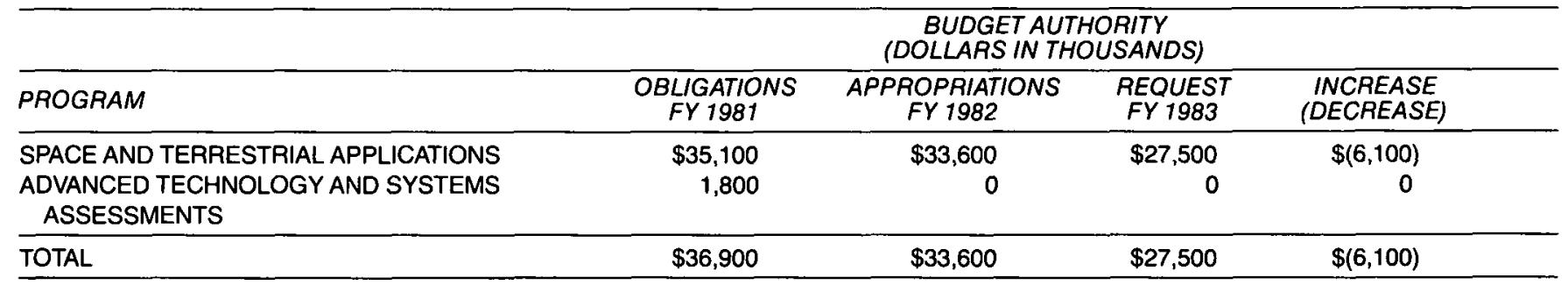

orbital and outerplanetary space missions, as well as for terrestrial applications.

Objectives. The principal objectives of the space and terrestrial systems applications program are:

- To provide the U.S. with a viable nuclear option for space power by continuing development of technology and qualification of isotope systems and reactor power systems.

- To develop and deliver qualified nuclear energy systems for use on approved U.S. space missions.

- To demonstrate the beneficial use of radioisotopes in various terrestrial applications.

The program currently consists of three projects: (1) Static Outerplanetary Radioisotope Thermoelectric Generator (RTG) Project, developing RTG's for NASA's Galileo mission and the International Solar Polar Mission; (2) Space Reactor Technology Program (SP-100), an advanced technology readiness program; and (3) a terrestrial RTG project that is classified.

In FY 1983, program activities have been narrowed to the major program element dealing with space applications of nuclear power sources. Beginning in FY 1982, responsibility for the terrestrial applications efforts on the Beneficial Uses of Radioisotopes has been transferred to Defense Waste Management.

Description. The Space and Terrestrial Applications Program has evolved from efforts to develop nuclear power for aerospace applications since the early 1950's. The Department and its predecessor agencies have provided nuclear expertise for missions of the National Aeronautics and Space Administration, the Department of Defense, and other Federal users.

A radioisotope thermoelectric generator basically utilizes the heat from a radioactive material, plutonium-238, to produce electrical power. The heat source is one of the two major components of an RTG, the other being the thermoelectric converter. The converter uses silicon-germanium elements to provide the spacecraft unregulated DC power. The design is modularized to allow for ease of increase in power for future designs. The General Purpose Heat Source (GPHS) represents a significant increase in the state of the art of thermoelectric conversion. Compared to the Multi-Hundred Watt (MHW) RTG used in the Voyager I and II missions, the GPHS yields almost 40 percent more power per pound. The power, between 255 and 290 watts, is used to operate equipment aboard the spacecraft, such as transmitters and cameras, as well as heat critical components during long-term exposure to the extremely cold temperatures of outer space. Since the first satellite and terrestrial missions in 1961, the RTG's have met or exceeded all design goals with over 99 percent reliability.

The Space Nuclear Systems program is divided into flight systems development and flight systems support elements.

\section{a. Flight Systems Development}

This program element includes the design, development, fabrication, and assembly of the isotope space power converter subsystems for the NASA Galileo and NASA European Space Agency International Solar Polar Mission (ISPM) spacecraft. The isotope qualification converter and several flight converters will be supported by this subprogram element throughout the flight acceptance and qualifiction levels of tests at Mound Facility. The Updated Safety Analysis Reports for both missions are planned to be published. DOE has initiated discussions with NASA to expand reimbursable work to include the qualification and spare flight units.

As currently programmed, the Space Reactor Technology Program (SP-100) will be continued in collaboration with NASA. Coordination with NASA and the Defense Advanced Research Projects Agency (DARPA) is now underway with a view to establishing an expanded tri-agency program (DOE, NASA, and DOD) with the DOE as the lead agency responsible for technology and development of the space reactor subsystem. Experimental work to demonstrate technology readiness of the reactor core heat pipe heat transfer system, material characterization and compatibility, irradiation component testing, and reactor control activities will be pursued. Current space reactor component attributes are targeted for a power system at the $100 \mathrm{~kW}(\mathrm{e})$ level in the $1800 \mathrm{~kg}$ to $2500 \mathrm{~kg}$ weight range. Overall system performance characteristics are aimed toward NASA and DOD missions in the 1990's.

\section{b. Flight Systems Support}

This program element supports fuel form production, encapsulation, heat source component manufacturing and assembly, environmental testing of the fueled flight units, and the overall independent safety and safety testing activities. In FY 1983, a significant manufacturing and testing program must be pursued both to meet the tight delivery schedules and the rigorous quality and safety requirements of the program. Iridium blanks fabricated at the Oak Ridge National Laboratory will be provided to the Mound 
Facility where the iridium is formed into fuel capsule containers. The Savannah River Plant will manufacture 63watt thermal pellets of plutonium-238 and encapsulate them into the iridium containers provided by the Mound Facility.

Graphitic heat source parts will be procured, fabricated, and assembled for final installation into the thermoelectric converter hardware by Mound Facility staff. Safety analyses and safety testing by the Los Alamos National Laboratory will be conducted on representative flight isotope hardware components to assess the safety margin of the system.

Certain ongoing activities will not be conducted beginning in FY 1983. The independent technical and quality assurance efforts, which support both the flight development and research work, will be phased out. Also, reduction of fuel form production and encapsulation operations at Savannah River Plant is under consideration, in addition to the reduction of assembly and testing operations of flight fueled units at the Mound Facility, and converter fabrication work at General Electric, Valley Forge, Pennsylvania. In addition, the advanced modular isotope generator technology program will not be continued.

Mission system development work is usually performed by industrial contractors. Fuel and safety research and development, special metals technology research, capsule hardware fabrication, and heatsource assembly are done in Government-owned contractor-operated laboratories and plants because these operations depend on the nuclear facilities, equipment, and expertise maintained for nuclear fuel and weapons programs. Other activities performed by industrial or institutional contractors include: quality assurance and reliability monitoring; isotope materials and capsule development; environmental impact and safety evaluation; advanced studies on thermoelectric materials and mission-requirement projections; technical consultation; and development and delivery of qualified nuclear energy systems for use on approved U.S. space missions; i.e., the NASA Galileo Mission scheduled for launch in March 1985, and the International Solar Polar Mission scheduled for launch in 1986. This includes related fuel form production, encapsulation, safety testing and analysis.

Continuing progress is being made in developing power systems of greater compactness, lighter weight, and improved conversion efficiency and safety. The Flight Systems Development program uses all available innovations in materials and design to accommodate the increasing power requirements of specific planned missions. In addition, the requirements of this program stimulate and guide the related power systems technology and support activities, as well as those of space power system safety and fuel development and production.

Implementation/Strategy. DOE provides for the initial design, development, demonstration, and quality assurance of space nuclear power systems to meet user mission objectives. As the space nuclear systems become more routine in character, user agencies will take on the respon- sibilities to plan and budget for follow-on systems and DOE will support such activities on a reimbursable basis.

For space nuclear systems, management policy permits funding of the first-of-a-kind nuclear systems, with the costs for follow-on flight systems being reimbursable to DOE. In certain cases, planning carries a developmental system through to a point of technology readiness only; the remaining flight development and demonstration costs are borne by the user agency.

Program logic includes the coordination of the space nuclear power development program with the user agencies to assure that the program activities are in keeping with user needs. Formal interagency agreements are used on specified space missions.

The directions the program takes are determined both by user agency product requests and by initiatives indicated by user trends and technology developments. Before a major application effort starts, cost/benefit analyses are conducted when the development risks and potential benefits can be meaningfully identified in advance. These analyses include mission and commercial requirements; environmental, health, and safety requirements; and specific needs (such as reliability, longevity, survivability, and quality assurance); and consider non-nuclear as well as nuclear alternatives. Program work is undertaken in concert with appropriate interagency formal agreements. Liaison between DOE, NASA, and other user agencies is pursued at several management levels through the medium of coordinating boards with both technical and administrative membership. These interagency coordinating groups provide the information on which the direction of the advanced research and technology activities is focused.

As the technology and support programs advance and are integrated into a system technology, user hardware requirements are specified and the system development and fabrication activities begin. The appropriate environmental assessments and impact statements, preliminary and final safety analysis reports, safety testing, evaluations, and fuel fabrication and assembly are done concurrently with the system development. Upon completion and acceptance testing, the end product is delivered to the user for operational use.

Accomplishments. The recent spectacular flights by Jupiter and Saturn of the NASA spacecraft VOYAGER and PIONEER have also marked additional milestones in the continuing successful and safe use of nuclear electric power in outer space. Since 1961, the United States has launched 22 NASA and military spacecraft having all or part of their power requiremente eupplied by nuclear power sources. Twenty-one of these spacecraft were powered by RTG's and one by a nuclear reactor. The history of these sources has shown that they can be safely and reliably built and launched to meet a variety of mission objectives. Future missions committed to nuclear power include NASA's GALILEO mission, which will launch an orbiter and atmospheric probe to Jupiter and the International Solar Polar Mission which will obtain scientific data on the sun and solar wind from high latitudes. 
Within the last 6 years, significant progress has been made in increasing the thermal output from the radioisotope heat sources, and improving the efficiency in the static thermoelectric converters. For example, the heat sources aboard the Viking landers on Mars each delivered about 680 thermal watts, yielding a power output of 40 watts at a conversion efficiency of approximately 6 percent. In contrast, the Multi-Hundred-Watt (MHW) heat sources powering the LES 8 and 9 communications satellites for the USAF and the NASA Voyager spacecraft for outerplanetary exploration each delivered 2400 thermal watts, yielding nearly 160 watts at an efficiency just under 7 percent. The dramatic photographs transmitted from Jupiter and Saturn by the Voyager spacecraft were possible only through the use of such nuclear power systems.

The major accomplishments in FY 1981 were:

- Continued development of advanced thermoelectric materials and power modules.

- Identification and evaluation of applications for space nuclear power systems for missions up to the year 2000.
- Completed fabrication of radioisotope heater unit components.

- Delivered MHW fuel sphere assemblies for safety testing.

Major planned accomplishments in FY 1982 are:

- Begin testing of the qualification GPHS-RTG.

- Continue fabrication and testing of Galileo and ISPM components.

- Continue SP-100 space reactor development.

- Continue safety analysis reviews for Galileo and ISPM.

Major planned accomplishments in FY 1983 are:

- Complete GPHS-RTG qualification test.

- Fuel and test first flight unit.

- Prepare development plan, recommend baseline design, and initiate component testing for SP-100.

- Conduct heat source fabrication, generator fueling, and acceptance testing for Galileo to ISPM.

Resources. The following table shows the operating funding levels for the FY 1981 through FY 1983 period.

SPACE AND TERRESTRIAL APPLICATIONS

\begin{tabular}{lcccc}
\hline & \multicolumn{5}{c}{$\begin{array}{c}\text { BUDGET AUTHORITY } \\
\text { (DOLLARS IN THOUSANDS) }\end{array}$} \\
\hline PROGRAM ELEMENT & OBLIGATIONS & APPROPRIATIONS & REQUEST \\
FY 1981 & FY 1982 & $\begin{array}{c}\text { INCREASE 1983 } \\
\text { (DECREASE) }\end{array}$ \\
\hline FLIGHT SYSTEMS DEVELOPMENT & 11,700 & 10,500 & 13,500 & 3,000 \\
FLIGHT SYSTEMS SUPPORT & 20,900 & 20,900 & 14,000 & $(6,900)$ \\
TERRESTRIALAPPLICATIONS & 2,500 & 2,200 & 0 & $(2,200)$ \\
\hline TOTAL & 35,100 & 33,600 & 27,500 & $(6,100)$ \\
\hline
\end{tabular}

Milestones. The key milestones for the Space Nuclear Systems program are shown in the summary milestone chart below.

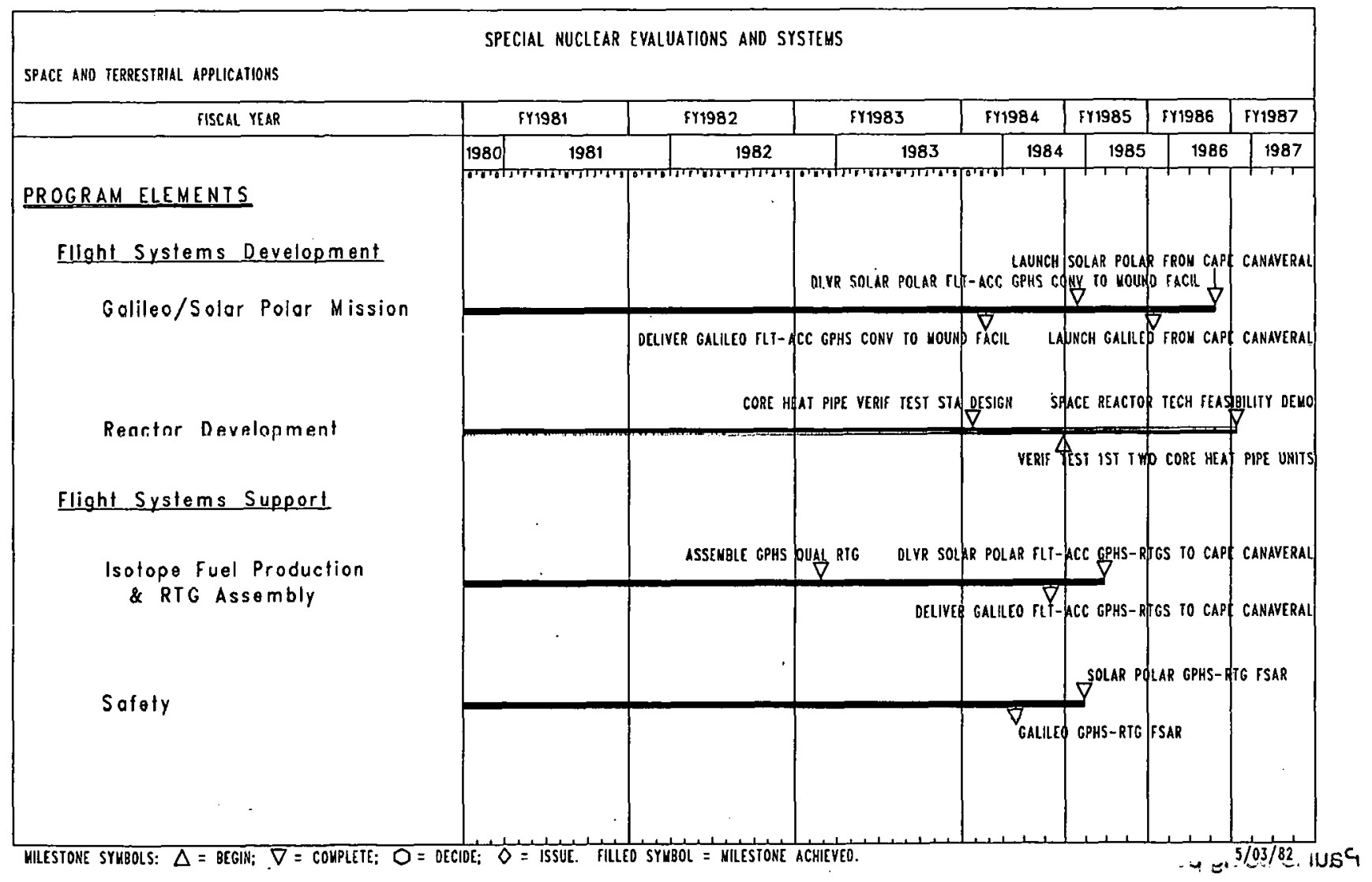




\section{Advanced Technology and Systems Assessments}

Every energy production plant began with a concept that was investigated, developed, and ultimately brought to the marketplace. Nuclear technology, no exception to this process, has nurtured many new ideas, some of which are improvements to existing technology; others foresee completely new technologies. It was the function of the work described in this section to compile the data and to conduct the analyses required to evaluate these new concepts.

Objectives. The basic objective of the Advanced Technology and Systems Assessments program is to provide to energy-related organizations, both in the Federal and non-Federal sectors, assessments of advanced nuclear systems and their applications to meet a broad range of the Nation's energy needs. These assessments include the technical, economic, environmental, social and institutional aspects and impacts of development and/or application. Associated with this objective was support of confirmatory research as required for assessment purposes.

Description. This assessment activity, which had been on-going for a number of years, has been terminated with completion of all activities planned in FY 1982 using, as far as practicable, prior year funding. The activity was structured principally to provide a screening mechanism to evaluate proposed new systems and systems applications, and to provide a basis for selection of those which have the potential of meeting both near-term and far-term needs for energy in the United States. New or advanced systems, and their associated applications, have been assessed and work terminated or emphasized, depending on the perceived potential for significant advances in specific energy-related areas. The sources of new approaches or ideas were not restricted, to help ensure that promising concepts would not be eliminated or overlooked.

This program for improving the applicability of nuclear energy was focused on two related elements: (1) applications to improve thermal utilization of energy produced by power reactors such as the concurrent production of electricity and use of thermal energy for district heating or for industrial processes; and (2) methods to increase the siting acceptability of power reactors, such as nuclear energy centers, advanced cooling systems for application in water-short regions, establishment of powerplant siting criteria to mitigate the impacts of waste heat releases, and the maintenance and update of a computerized system to predict where and when less water consumptive cooling methods would be needed in the U.S.

Implementation/Strategy. In the area of increased thermal utilization, planning and design studies in the cogeneration area directed towards implementation of a 200 MWt hot water district heating system in St. Paul were completed in FY 1981, with partial support by the Department of Energy. The construction phase for this system for St. Paul is being pursued by the city, using an existing coal- fired powerplant as the energy source. However, since the Twin Cities area (Minneapolis and St. Paul) could require up to the order of $4000 \mathrm{MWt}$ if full hot water district heating were employed, a study has been initiated to evaluate the possible economic and technical feasibility of retrofitting the two existing Prairie Island nuclear powerplants near Red Wing, Minnesota, to supply the required thermal energy. This study is planned for completion in early FY 1982. It should be noted that the 35-mile distance from these two plants to the Twin Cities is well within the acceptable distance for hot water transmission based on established European experience. It is of principal importance that the Prairie Island study will provide generic data on the technology of retrofitting central station nuclear plants for cogeneration, as a national option.

Past studies of cogeneration for industrial process heat using intermediate slze (1200-MWt) nuclear powerplants indicated that they have the capability of displacing oil and natural gas and producing industrial process steam at lower cost than alternative methods. In this regard, studies of a cogeneration energy source to provide both electric power and process steam for a "grass roots" model industrial center in the Gulf Coast area will be completed in FY 1982. In such a center, the steam requirements of the industries would be compatible with those available from co-located powerplants.

One of the major concerns related to the use of nuclear power (in fact, all central station power) is plant siting. Although nuclear plants do not emit combustion gases and particulates, they do require large quantities of water for cooling and large areas of land for exclusion boundaries. They also reject large quantities of heat and moisture when evaporative cooling is utilized. The meteorological impacts of such heat and moisture releases need to be assessed in order to mitigate any undesirable environmental effects through improved plant siting techniques. Such effects

may be enhancement or redistribution of rainfall or snowfall, fogging, or cloud shadowing. In addition, siting of powerplants in water short areas or areas where there are major competing demands for water calls for less water consumptive cooling methods such as dry or wet/dry cooling. Increased population limitations and other reasons may also favor the clustering of a number of nuclear plants at a single location termed a nuclear energy center.

Particular projects to be completed in FY 1982 in the area of increased siting acceptability are the study of a 9unit nuclear energy center located at Green River, Utah (cooperatively conducted with the State of Utah), and a 5year project on the meteorological effects of thermal energy release (METER) including validated predictive atmospheric models. Support of operations of the DOE Electric Power Research Institute/utilities advanced wet/dry powerplant cooling system test unit at a Pacific Gas and Electric power station site will be terminated at the end of FY 1982, as will support of the cooling water availability/ use data bank at the Hanford Engineering Development Laboratory. 
Accomplishments. The following activities were completed in FY 1981:

- Planning phase for St. Paul 200 MWt district heating system.

- South Carolina energy center study.

- Large-scale field tests of the effects of cooling tower heat and moisture releases on meteorology.

- Revised assessment of water resources for cooling electric generating units.

- Data acquisition system, safety analysis, and test plan for advanced powerplant cooling test unit.

The FY 1982 accomplishments are directly associated with the completion of the following activities during this fiscal year.
- Utah Energy Center Study.

- Feasibility of retrofitting the Prairie Island nuclear plants for cogeneration/district heating.

- Support of the DOE/EPRVutilities wet/dry cooling test unit.

- Analysis of nuclear cogeneration/process heat at a new industrial site.

- Analysis of the future need for and location of advanced cooling systems.

- Analysis of meteorological effects of powerplant heat and moisture releases.

No program activities are planned for FY 1983.

Resources. The following table shows the operating funding levels for the FY 1981 thorugh FY 1983 period.

\begin{tabular}{lccc}
\multicolumn{4}{c}{ ADVANCED TECHNOLOGY AND SYSTEMS ASSESSMENTS } \\
\hline PROGRAM ELEMENT & & $\begin{array}{c}\text { BUDGET AUTHORITY } \\
\text { (DOLLARS IN THOUSANDS) }\end{array}$ \\
\hline IMPROVED THERMAL UTILIZATION & OBLIGATIONS & APPROPRIATIONS \\
FY 1982 & $\begin{array}{c}\text { REQUEST } \\
\text { FY 1983 }\end{array}$ \\
INCREASED SITING ACCEPTABILITY & 700 & 0 & 0 \\
\hline TOTAL & 1,100 & 0 & 0 \\
\hline
\end{tabular}

Milestones. Major milestones for the Advanced Technology and Systems Assessment program are shown in the chart below.

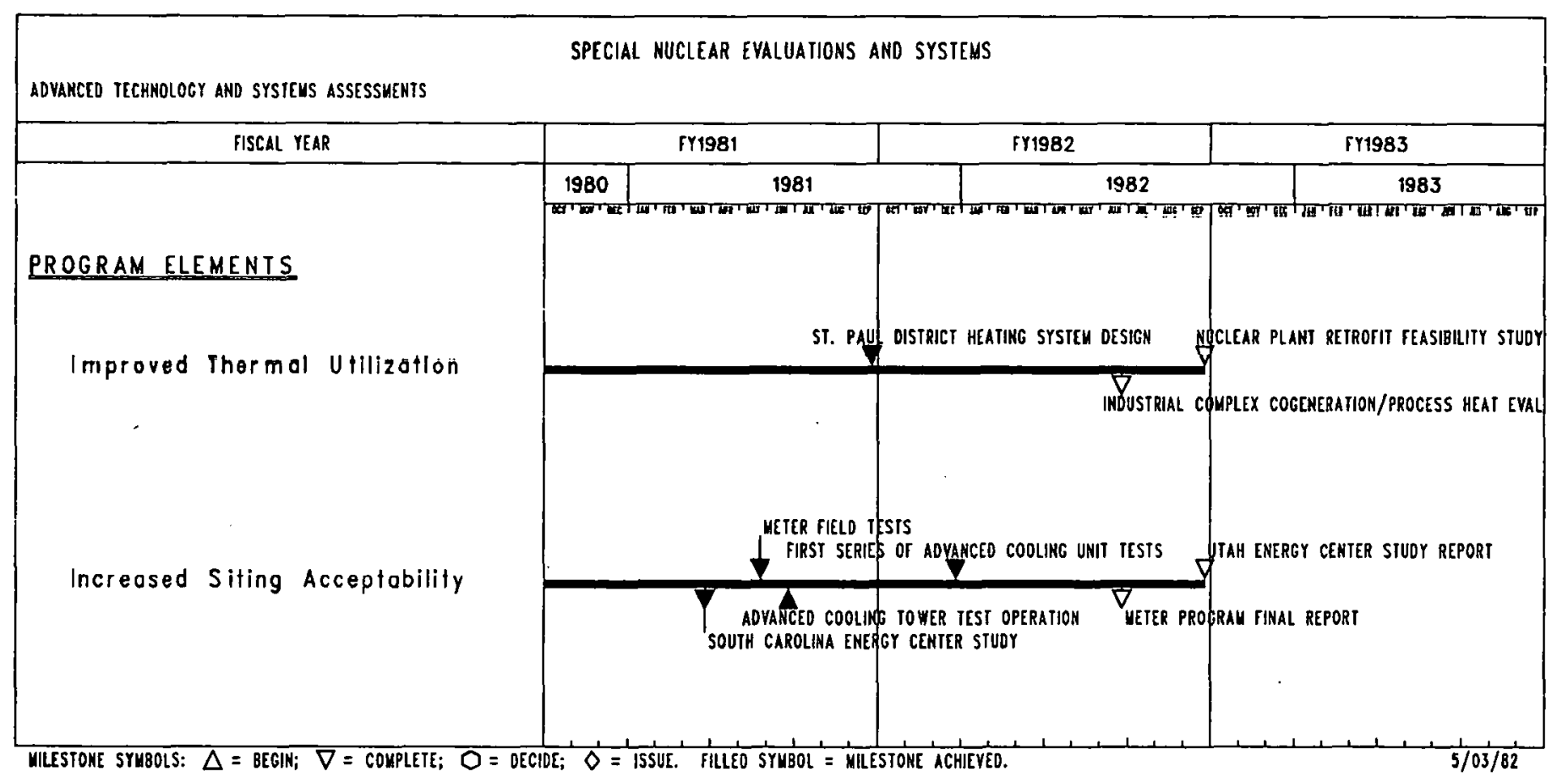




\section{PROGRAM MANAGEMENT}

This chapter describes the structure of the fission energy program and summarizes the management approach and tools used in its execution and control.

\section{A. Management Philosophy}

The management philosophy used in the civilian reactor development program is a product-oriented, management-by-objectives system. The principal management functions and their interrelationships, as shown in Figure 9, are to:

- Establish program goals in accordance with national energy policy;

- Establish a comprehensive plan and schedule to achieve these goals;

- Determine and secure resources required to execute the plan;

- Separate the total program scope into manageable work segments and assign responsibility and resources to contractors for work segment execution;

- Monitor and measure progress of the program against resources expended, taking corrective action as necessary; and

- Revise the overall plan and redirect subordinate plans as necessary to accommodate changes imposed by:

- external forces, such as, changes in national energy policy, projected need dates, budget actions, etc., and

- internal events, such as, new technological findings in the program, unforeseen delays, etc.

The organizational structure and management approach used by the civilian reactor development programs are described in Section III-B. Program assurance, safequards and security aspects common to all fission energy programs are discussed in Section III-C.

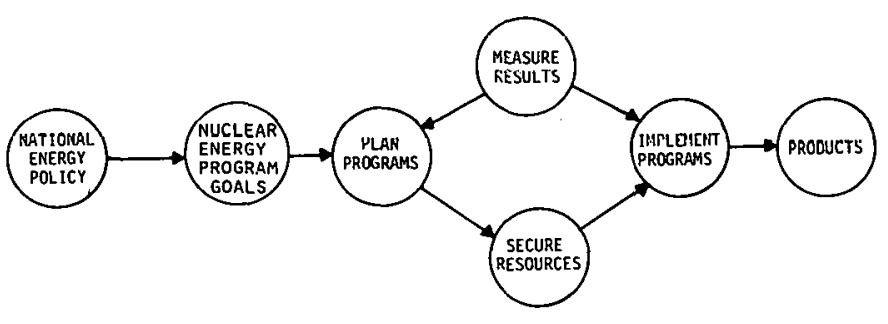

Figure 9. Fission energy program management functions and interrelationships.

\section{B. Organization}

\section{Program Functional Elements}

The three generic functional elements in the civilian reactor development program are:

- Developmental and demonstration projects;

- Base technology programs; and

- Supporting facilities.

A complete developmental program contains all three elements. Developmental and demonstratlon projects bring all elements of the program together, resulting in the necessary technology needed by industry for commercialization. The scope and timing of the projects drive the remainder of the program. Technology development (in such areas as nuclear fuels, safety, and components) supports specific project requirements and provides the basis for continued progress between successive projects. Test facilities are necessary to support both the base technology programs and to confirm performance of project systems. The relationships of projects, base technology programs, and facilities are illustrated in Figure 10.

The DOE fission energy program elements include a varying range of balance among the three basic functional elements; i.e., some program elements include substantial work in all three, while others are limited to basic technology development with no plans for demonstration projects. However, the intent in most cases is to develop a supporting technology base through basic development activities, utilize test facilities as appropriate to contribute to the technology program, and ultimately to demonstrate the technology on a scale that ranges from testing in existing commercial facilities lo comslrucling anud operating dedi= cated Government-owned facilities.

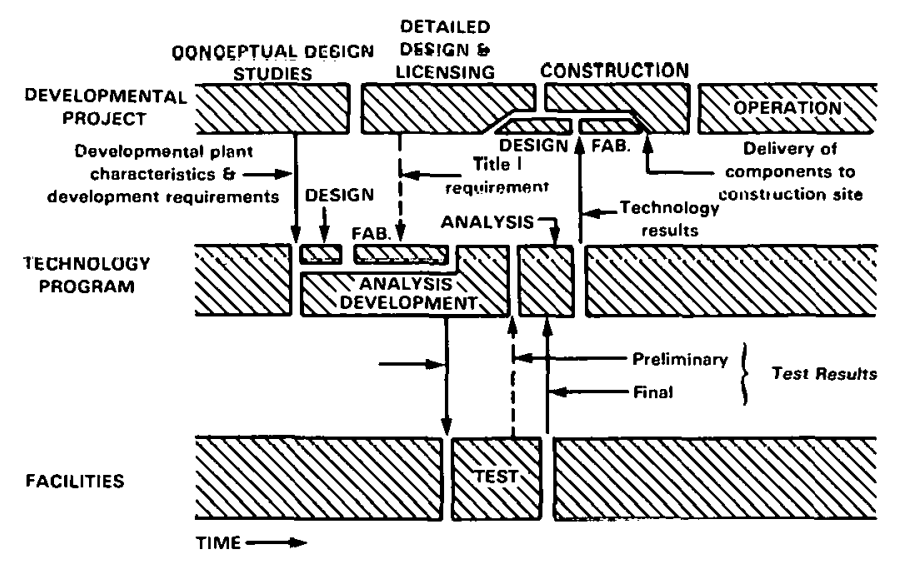

Figure 10. Relationships among projects, technology programs, and facilities. 


\section{Work Breakdown Structure}

The work breakdown structure (WBS) is one of the most useful and important tools in the planning and control of fission energy programs and projects. By definition, a WBS is a product-oriented logic diagram depicting the hardware, services, and data that comprise a program. In such a diagram, the work elements relate to one another through an integrated hierarchy leading to the end product. Thus, the WBS diagram graphically represents the various efforts required, how they interact, and the sequence that is required for success.

Delineation of a WBS begins with the broadest definition of the program (e.g., fission energy) or project to be described. Each of the work elements required for completion is successively subdivided into progressively smaller units until at the lowest level each element in the WBS represents a discrete package of relatively short duration, with a definite beginning and end, and to which a specific budget can be assigned. Completion of all these packages constitutes completion of the program or project, and the summation of the costs of the individual packages yields the total cost of the project.

Thus, a WBS is both a planning tool, in which all activities required for the completion of a program are carefully planned in advance, and a control mechanism that enables close monitoring of progress in terms of objectives (milestones), schedule, and cost. The WBS approach has been adopted as an integral part of the technical and budgetary management of the entire fission energy program and its subdivisions.

Within the Department of Energy, the Assistant Secretary for Nuclear Energy (ASNE) administers the research and development programs associated with fission energy and the management of radioactive wastes. Waste management actlvities and uranium enrichment and resource activities are covered in separate program summary documents.

The civilian reactor development R\&D activity is divided into three categories under the supervision of the Deputy Assistant Secretary for Nuclear Reactor Programs and the Deputy Assistant Secretary for Naval Reactor Programs: Converter Reactor Systems, Breeder Reactor Systems, and Special Nuclear Evaluations and Systems. Figure 11 shows the first three levels of the fission energy WBS for civilian nuclear programs. The uppermost Level I includes all the activities under the cognizance of the Deputy Assistant Secretary for Nuclear Reactor Programs, and one activity under the cognizance of the Deputy Assistant Secretary for Naval Reactors. Level 2 defines the major subdivisions of the program. Each of these has fission as a common element, but they differ in basic application or uses. Subdivisions at Level 3 are identified by a particular end product (e.g., LWR or LMFBR). Each major subdivision at Level 2 is described in a separate section in this document, and each of the end products in Level 3 constitutes an individual program.

Levels 4 and below show projects and their supporting activities. A WBS for a typical major construction project, which would be represented at Level 4 or below, is shown in Figure 12. Further breakdowns of the Level 3 program elements are presented in the sections of this document in which those elements are described.

\section{Organizational Structure and Delineation of Responsibilities}

With the exception of the water cooled breeder; program, the Deputy Assistant Secretary for Nuclear Reactor Programs implements the civilian reactor development program in accordance with policy established by the Assistant Secretary for Nuclear Energy. Figure 13 is an organization chart showing the offices under this Deputy Assistant Secretary. The water cooled breeder program is implemented by the Deputy Assistant Secretary for Naval Reactors.

A task-responsibility matrix depicting the relationship between the WBS and the organizational structure is shown in Figure 14. The WBS program structure down to Level 3 is shown along the top, and the organizational units (to the office level) responsible for the work are shown along the left side. Responsibilities are indicated by circles at the intersections of the horizontal and vertical lines.

It is DOE policy to decentralize program and project management activities. While overall program responsibilities are retained at Headquarters, project management responsibilities are delegated to DOE Field and Project Offices.

Headquarters role. Headquarters is responsible for the overall implementation of the fission energy program in accordance with upper DOE management policies. Headquarters does this by:

- Developing program plans, budgets, and resource aliocation requirements;

- Working with the Office of Management and Budget, Congress, Federal and State agencies, industry, universities, the governments of other nations, and international organizations to coordinate fission energy activities;

- Providing program guidance and resources to DOE Field and Project Offices for implementation; and

- Monitoring program execution with DOE Field and Project Offices to ensure that programs are being implemented as planned.

Field and Project Office roles. The DOE Field and Project Offices are responsible for implementing the programs in conformance with the guidance and resources provided by Headquarters. The Field and Project Offices do this by:

- Developing detailed program and project plans, budgets and resource allocations needed to execute the programs as planned;

- Contracting for the goods and services required to conduct the programs; and 
- Measuring actual cost and schedule performance versus planned performance, and taking or recommend-

ing corrective action as necessary.

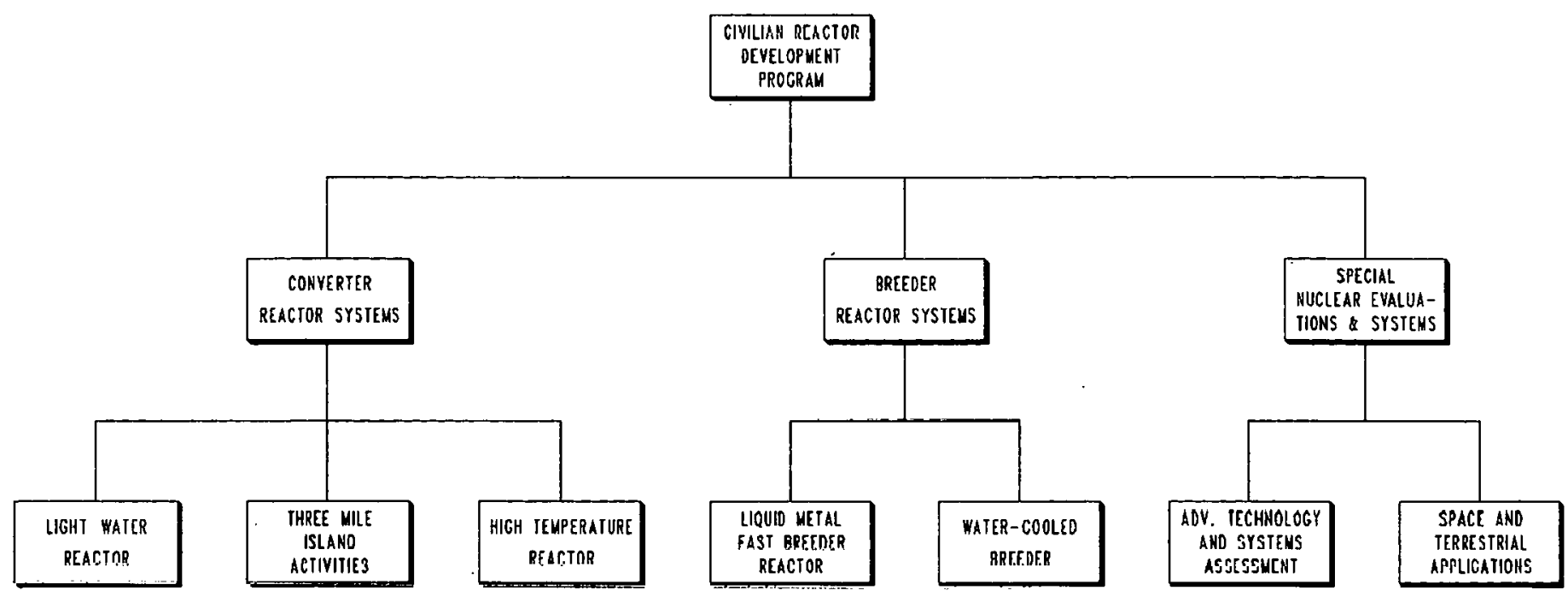

Figure 11. Civilian reactor development program upper-level work breakdown structure.

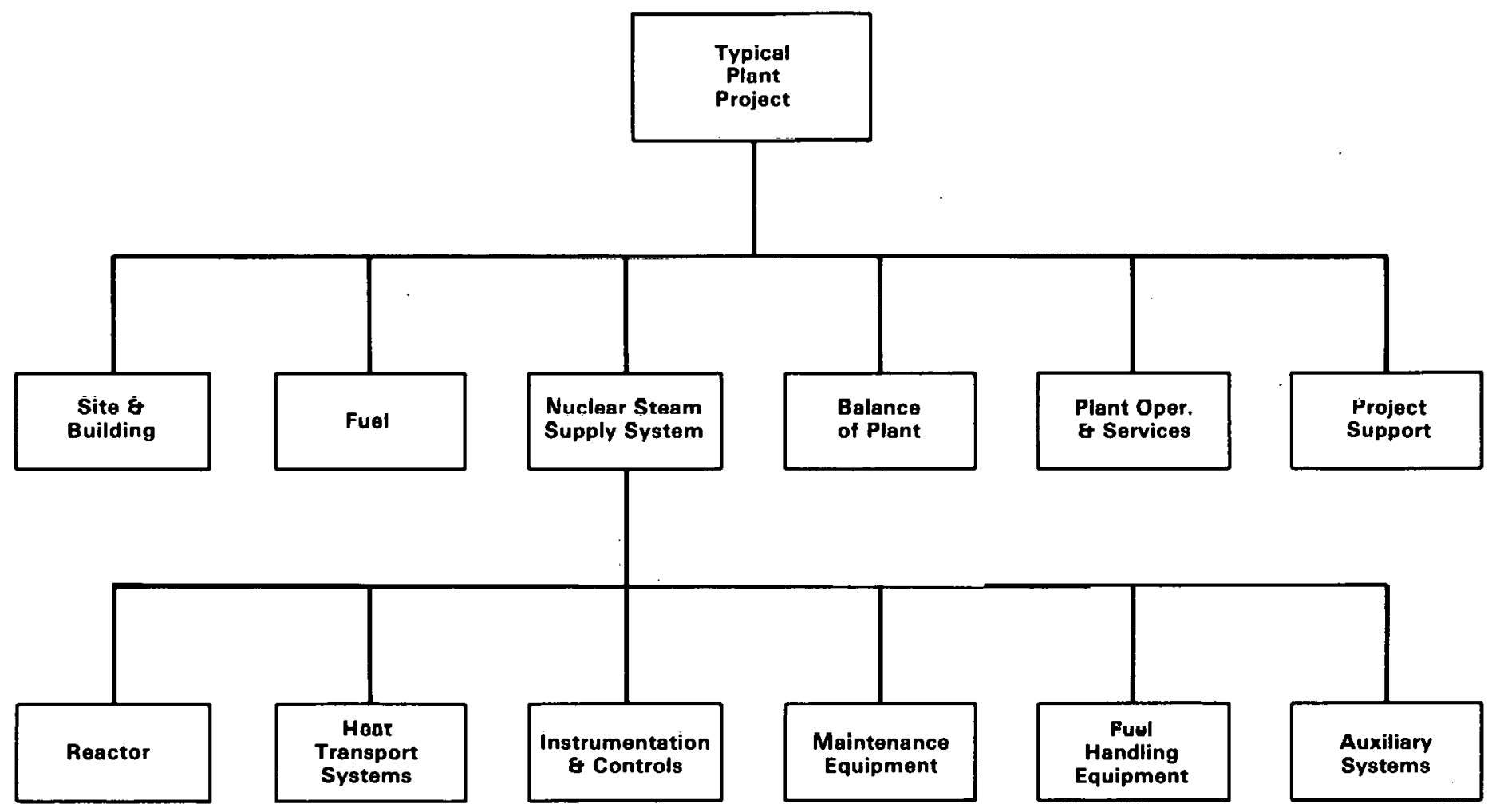

Figure 12. Work breakdown structure for a typical plant project. 


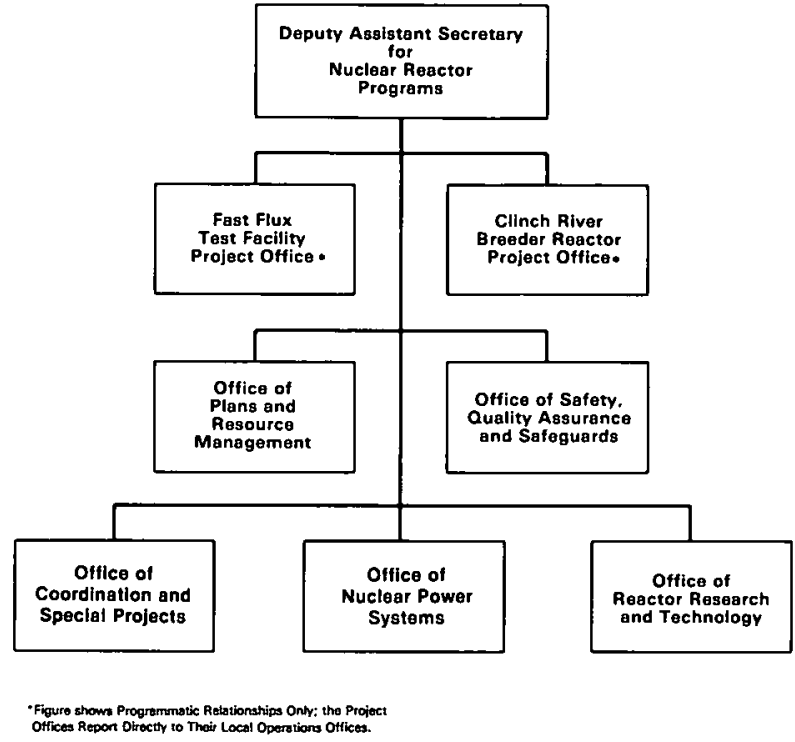

Figure 13. Organization of the Office of the Deputy Assistant Secretary for Nuclear Reactor Programs.

Contractors' roles. The contractors, which include national laboratories, universities, and industry, are responsible for program execution. They accomplish this by:

- Initiating proposals or responding to requests for proposals from DOE Field and Project Offices;
- Assisting in the development of detailed program plans; and

- Carrying out the technical program in accordance with the guidance provided by the Field and Project Offices.

\section{Program Planning, Budgeting and Control}

The Department of Energy provides a mechanism for the systematic consideration of program and resource allocation issues, with strong focus on multiyear programs. To accomplish this, formal documentation is prepared to present plans in programmatic resource terms.

The fission energy program planning documents provide clear visibility as to the course to be followed, and serve as contracts between organizational units--both vertically and laterally in the management structure. Plans and planning documentation are not static, however. They must accommodate changes resulting from events both external and internal to the program. Such program changes are made in an orderly and coherent manner with full recognition of programmatic and budgetary impacts.

The documentation identified in Figure 15 constitutes a hierarchy of planning documents for managing the program. Detail and numbers of documents increase from top to bottom of the planning hierarchy. This architecture pro-

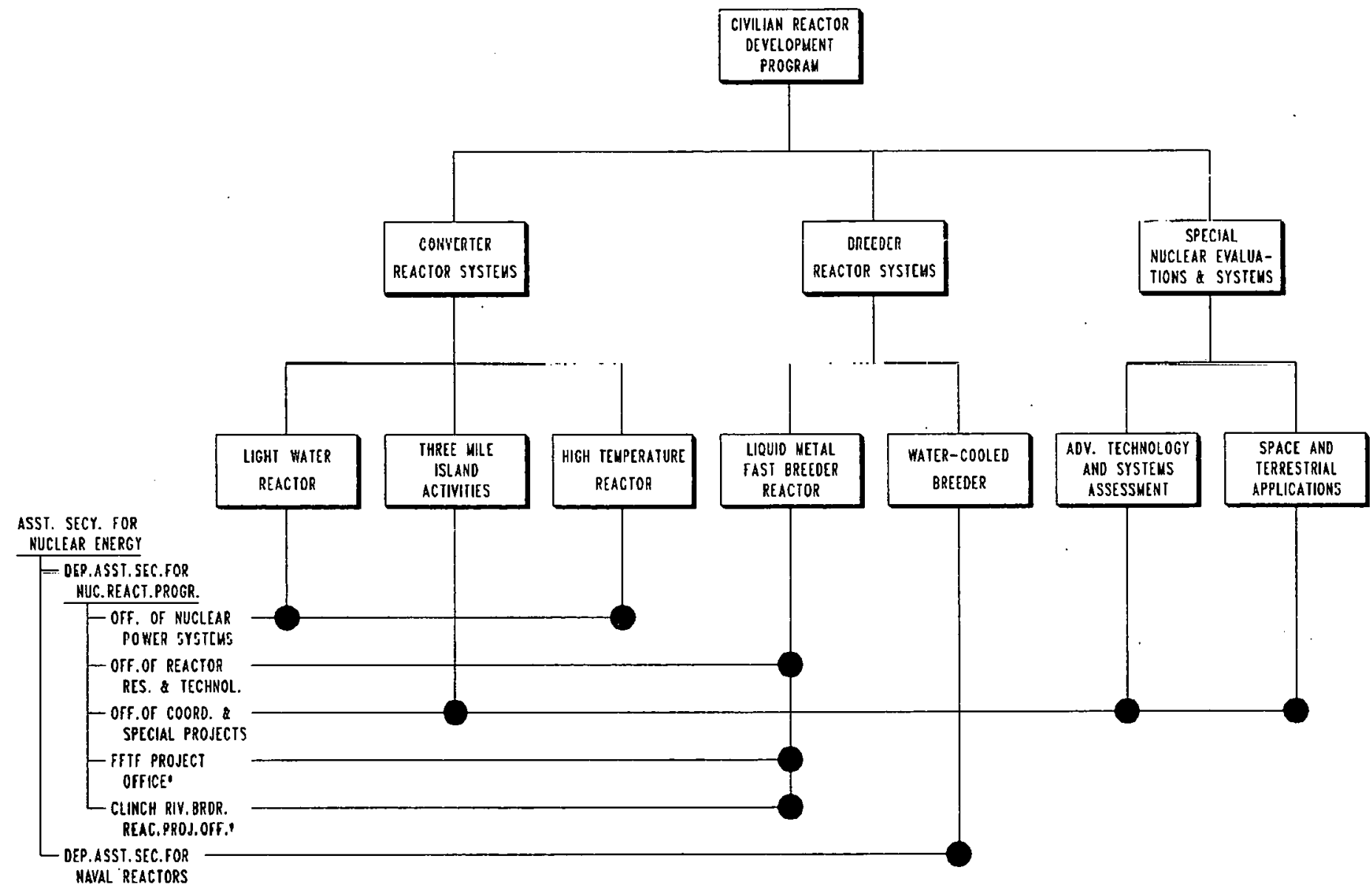

NOTE: - FIGURE SHOWS PROGRAWHATIC RELATIONSHIPS ONLY; PROJECT OFEICES REPORT DIRECTLY TO THEIR LOCAL OPERATIONS OFFICES.

Figure 14. Relationship between Civilian Reactor Development Program organizational structure and program WBS. 
vides the structure through which policy and technical and fiscal guidance are communicated downward and through which program progress, cost, schedule, and technical data are reported upward. All major planning documents are updated no less than annually in accordance with the planning and budget cycle of the Federal Government. As shown in the figure, overall guidance is provided through national energy policy emerging from both the Executive and Legislative branches of the Government.
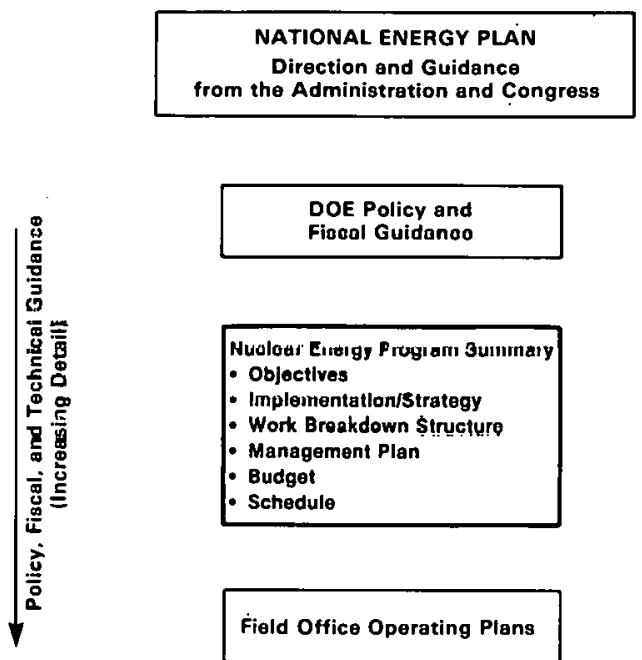

Field Office Operating Plans

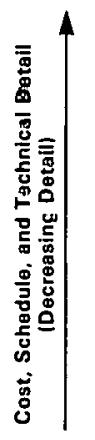

Detailed Contractor Work Plans

Figure 15. Hierarchy of management planning documents.

Program control is achieved through the use of an established hierarchy of milestones emerging from the various levels of the work breakdown structure. Milestones have been arranged in terms of their relative importance to allow their control at appropriate management levels. The presentation of milestones in this document reflects these efforts.

\section{Program Assurance, Safeguards and Security}

\section{Program Assurance}

A program assurance function is conducted to help assure that nuclear energy programs under the jurisdiction of the ASNE are carried out in a safe, reliable, and effective manner. Included are activities directed at assuring the safe operation of nuclear energy projects and programs; at the development and implementation of quality assurance programs; and at the development and application of engineering standards. In all three of these activities, the basic responsibility lies with the cognizant line program management organization. The program assurance function is responsible for establishing overall policies and guidelines for all ASNE activities; providing technical and managerial assistance to the line organizations; and advising the ASNE relative to these matters.

In the safety area, the responsibility is executed primarily by developing policies for nuclear safety; performing safety assessments for Safety Analysis Reports and other safety-related documentation; conducting safety appraisals of selected facilities; and reviewing, as necessary, field office nuclear safety programs. Two Safety Assessment Offices, one located at Argonne National Laboratory (ANL) and the other at Hanford Engineering Development Laboratory (HEDL), provide technical assistance in this area.

In the quality assurance area, the responsibility is executed by assisting nuclear energy managers in the establishment of effective quality assurance programs; in the development of quality assurance training programs; in the development of programr-specific quality assurance methods, standards and requirements; in preparing quality assurance information on acceplable practices, generic problems and solutions, and lessons learned; and in planning and participating in ASNE program quality assurance audits. The Nuclear Quâlity Assurance Program Uttice; located at HEDL, provides technical assistance in this area.

In the nuclear standards area, the responsibility is executed by assisting nuclear energy line program managers in the development and application of engineering standards; in the processing of changes to program-specific standards; in the management of the interface with voluntary consensus standards organizations; in the development of standards policy guidance and procedures; and in maintaining a nuclear energy standards data base. The Nuclear Standards Management Center, located at Oak Ridge National Laboratory, provides technical assistance in this area.

\section{Safeguards and Security}

Safeguards and security activities are being conducted to maintain and upgrade physical security systems, techniques, and procedures in conjunction with improved methods of control and accountability at ANL, HEDL, and the Idaho National Engineering Laboratory (INEL). These activities are being carried out to achieve integrated safeguards systems for DOE facilities dedicated to civilian nuclear energy programs that acquire, use, store, and dispose of special nuclear materials. It is intended that these upgrading activities will provide, to the maximum extent practicable, the protective measures necessary to detect and prevent loss or diversion of special nuclear materials from unauthorized use by insiders; prevent theft by outsiders; and protect nuclear materials and facilities against malevolent acts, attack, or intrusion.

The primary policies and guidelines for implementing these safeguards activities are set forth in DOE Orders which are currently being strengthened and updated to meet the more rigorous demands of today's environment. The overall scope of these guidelines encompasses a wide spectrum of operations, equipment, and construction activities that will ultimately be integrated and implemented in conformance with safeguards plans designed to meet the 
specific needs and characteristics of each facility or site. A significant portion of these upgrading efforts consists of line item construction projects which, because of budgetary considerations, have been implemented on a phased basis. Major construction at ANL, HEDL, and INEL was initiated during $F Y 1978,1979$, and 1980, respectively. An additional safeguards construction item will be initiated at
ANL during FY 1983 and it is planned that future efforts, including construction, will be implemented to further comply with emerging new requirements in DOE to meet such things as changing threat patterns and potential new obligations which may evolve from the December 1980 US/ IAEA Treaty Agreement. 


\section{APPENDIX A \\ Program Participants and Regional Distribution}

This appendix describes the types of contractors, their geographic distribution, and the roles of DOE's national and engineering laboratories in the civilian reactor development program.

\subsection{TYPES OF CONTRACTORS}

Table A-1 shows the breakdown of the fission energy program elements among the national and engineering laboratories, major industrial and utility contractors, and universities. In general, 40-50 percent of the work is carried out in the laboratories. The data in Table A-1 tend to understate the role of industry in the program, because over 65 percent of the program being conducted in DOE laboratories is performed in laboratories operated for the Government by industrial contractors, as opposed to those operated by universities. This is shown in Table A-2. When the total industry and university involvements are compared, the ratio is over five to one in favor of industry.

This is a most important aspect of fission energy program implementation, as the heavy industrial participation, even in the early laboratory development work, facilitates the transfer of technology when commercialization be- comes desirable. Table A-3 lists the operators, and Figure A-1 shows the locations of the major laboratories engaged in the fission energy program.

\subsection{GEOGRAPHIC DISTRIBUTION}

The geographic distribution of the program is shown by states in Table A-4. Significant activities are being carried out in 15 of the 50 states, but the heaviest concentrations are in the states where AEC (now DOE) laboratories were established during the early years of the program:

Tennessee
Washington
Idaho
Pennsylvania
Illinois
California
New Mexico

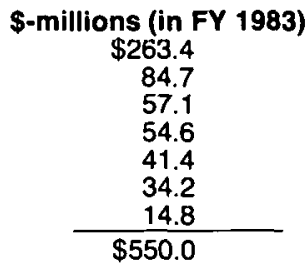

Tables A-5, A-6, and A-7 list the program participation by the major Government installations, major contractors (other than laboratory operators), and universities, arranged by the states in which the work is carried out.

Table A-1. Civilian Reactor Development Program Participation by Type of Institution

\begin{tabular}{|c|c|c|c|c|c|}
\hline \multirow[b]{2}{*}{ Type of insiltution } & \multicolumn{5}{|c|}{ FY 1983 participation in program, \$-million } \\
\hline & $\begin{array}{c}L W R \\
\text { Technology }\end{array}$ & LMFBR & WCE & $\begin{array}{c}\text { Space } \\
\text { \& Terrestrial } \\
\text { Appllcatlons }\end{array}$ & Total \\
\hline & 19.4 & 203.5 & 31.2 & 9.8 & 263.9 \\
\hline Major industrial and utility contractors* & 1.7 & 278.5 & 10.6 & 17.7 & 308.4 \\
\hline Universities* & 0.5 & 0 & 0 & 0 & 0.5 \\
\hline Total & 25.0 & 486.9 & 41.8 & 27.5 & 581.2 \\
\hline
\end{tabular}

Note: Figures do not total exactly because of rounding.

*Excluding contract operation of Government-owned installations. 


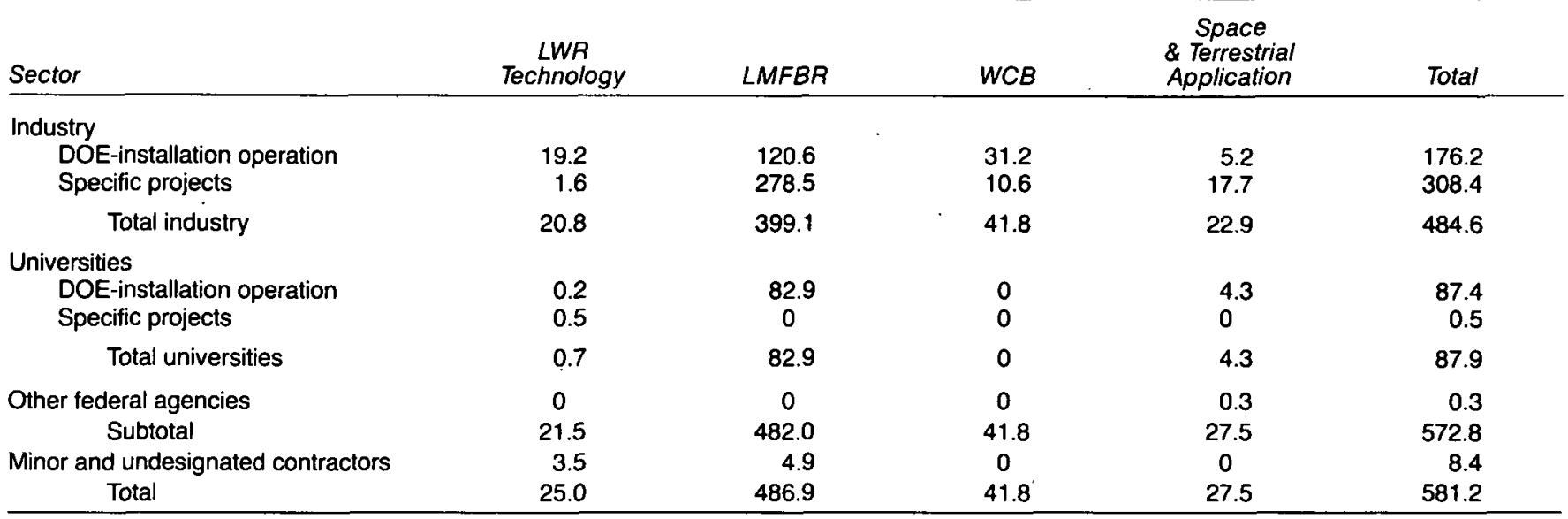

Note: Figures do not total exactly because of rounding.

Table A-3. Operators of DOE National and Engineering Laboratories

\begin{tabular}{|c|c|c|}
\hline Laboratory & $\begin{array}{c}\text { Map } \\
\text { ref. } \\
\text { (fig. A-1) }\end{array}$ & Operator \\
\hline $\begin{array}{l}\text { Ames Laboratory } \\
\text { Argonne National Laboratory } \\
\text { Bettis Atomic Power Laboratory } \\
\text { Brookhaven National Laboratory } \\
\text { Energy Technology Engineering Center } \\
\text { Hanford Engineering Development Laboratory } \\
\text { Idaho National Engineering Laboratory } \\
\text { Knolls Atomic Power Laboratory } \\
\text { Lawrence Berkeley Laboratory } \\
\text { Lawrence Livermore National Laboratory } \\
\text { Los Alamos National Laboratory } \\
\text { Mound Laboratory } \\
\text { Oak Ridge National Laboratory } \\
\text { Pacific Northwest Laboratory } \\
\text { Sandia National Labüraluilies } \\
\text { Cavannah Miver Laboratoly }\end{array}$ & $\begin{array}{l}\text { Ames } \\
\text { ANL } \\
\text { BAPL } \\
\text { BNL } \\
\text { ETEC } \\
\text { HEDL } \\
\text { INEL } \\
\text { KAPL } \\
\text { LBL } \\
\text { LLNL } \\
\text { LANL } \\
\text { Mound } \\
\text { ORNL } \\
\text { PNL } \\
\text { SNL } \\
\text { 3RL }\end{array}$ & $\begin{array}{l}\text { lowa State University } \\
\text { University of Chicago } \\
\text { Westinghouse Electric Corp. } \\
\text { Associated Universities of N.Y. } \\
\text { Rockwell International } \\
\text { Westinghouse Electric Corp. } \\
\text { Edgerton, Germeshausen and Grier, Inc. } \\
\text { General Electric Co. } \\
\text { University of California } \\
\text { University of California } \\
\text { University of California } \\
\text { Monsanto Research Corp. } \\
\text { Union Carbide Corp. } \\
\text { Battelle Memorial Institute } \\
\text { Western Electric Co. } \\
\text { C. I. Ju Füıl Je Nelıuuls \& Cu. }\end{array}$ \\
\hline
\end{tabular}

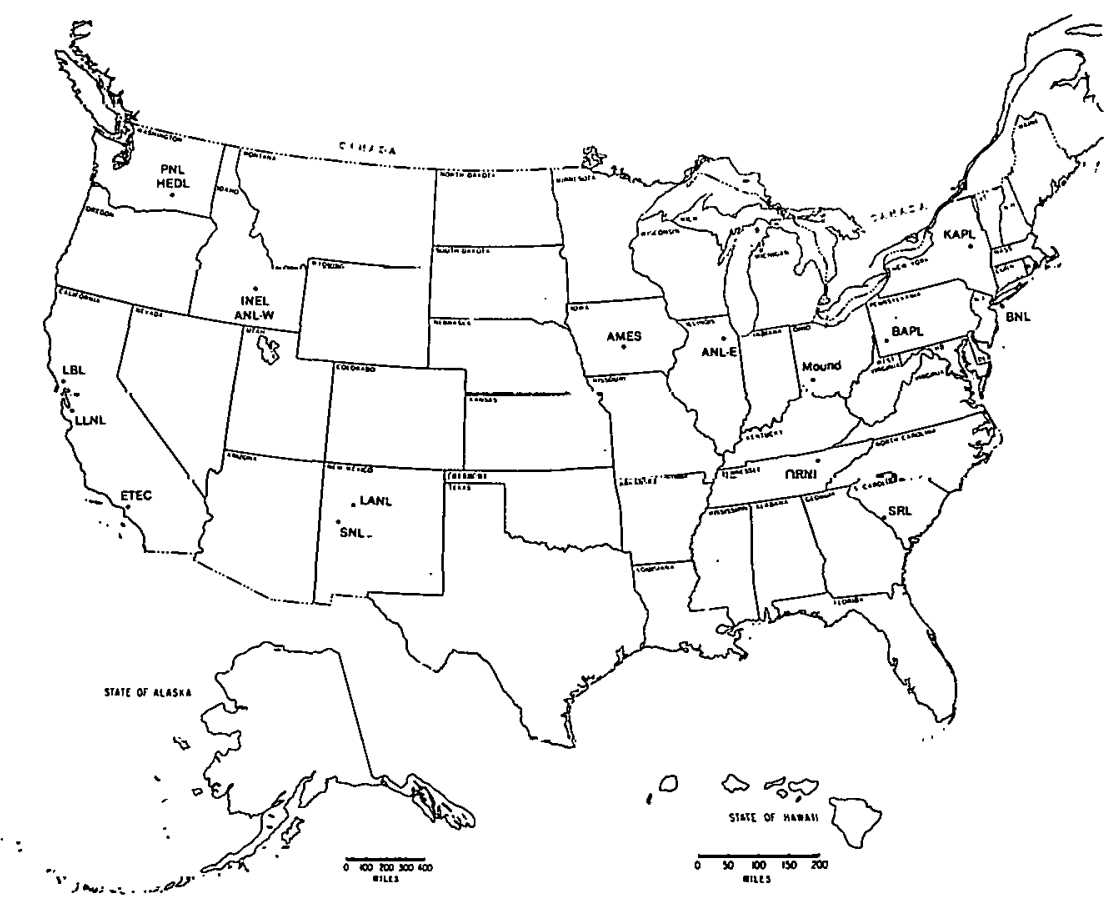

Figure A-1. Locations of DOE national and engineering laboratories. 


\begin{tabular}{|c|c|c|c|c|c|}
\hline \multirow[b]{2}{*}{ State } & \multicolumn{5}{|c|}{ FY 1983 participation in program (see chapter), \$-thousand } \\
\hline & $\begin{array}{c}\text { LWR } \\
\text { Technology }\end{array}$ & LMFBR & WCB & $\begin{array}{c}\text { Space } \\
\text { \& Terrestrial } \\
\text { Applications }\end{array}$ & Total \\
\hline $\begin{array}{l}\text { California } \\
\text { Connecticut }\end{array}$ & 250 & 33,900 & & & 34,150 \\
\hline $\begin{array}{l}\text { District of Columbia } \\
\text { Florida }\end{array}$ & 1,600 & $\begin{array}{l}4,900 \\
6,600\end{array}$ & & & $\begin{array}{l}6,500 \\
6,600\end{array}$ \\
\hline Georgia & 500 & & & & 500 \\
\hline Idaho & 19,250 & 34,800 & 3,000 & & 57,050 \\
\hline fllinois & 250 & 41,100 & & & 41,350 \\
\hline Maryland & & & & 500 & 500 \\
\hline Nebraska & 430 & & & & 430 \\
\hline New Mexico & 550 & 9,900 & & 4,300 & 14,750 \\
\hline Ohio & & & & 3,477 & 3,477 \\
\hline Pennsylvania & & 4,700 & 38,800 & 11,100 & 54,600 \\
\hline South Carolina & & & & 6,898 & 6,898 \\
\hline Tennessee & & 262,200 & & 1,225 & 263,425 \\
\hline Vir'ginia & 800 & 4,300 & & & 3,100 \\
\hline Washington & 150 & 84,500 & & & 84,650 \\
\hline Unilown & 1,200 & & & & 1,200 \\
\hline TOTAL & 25,000 & 486,900 & 41,800 & 27,500 & 581,200 \\
\hline
\end{tabular}

Table A-5. Civilian Reactor Development Program Participation by National Laboratories and Other Government Installations

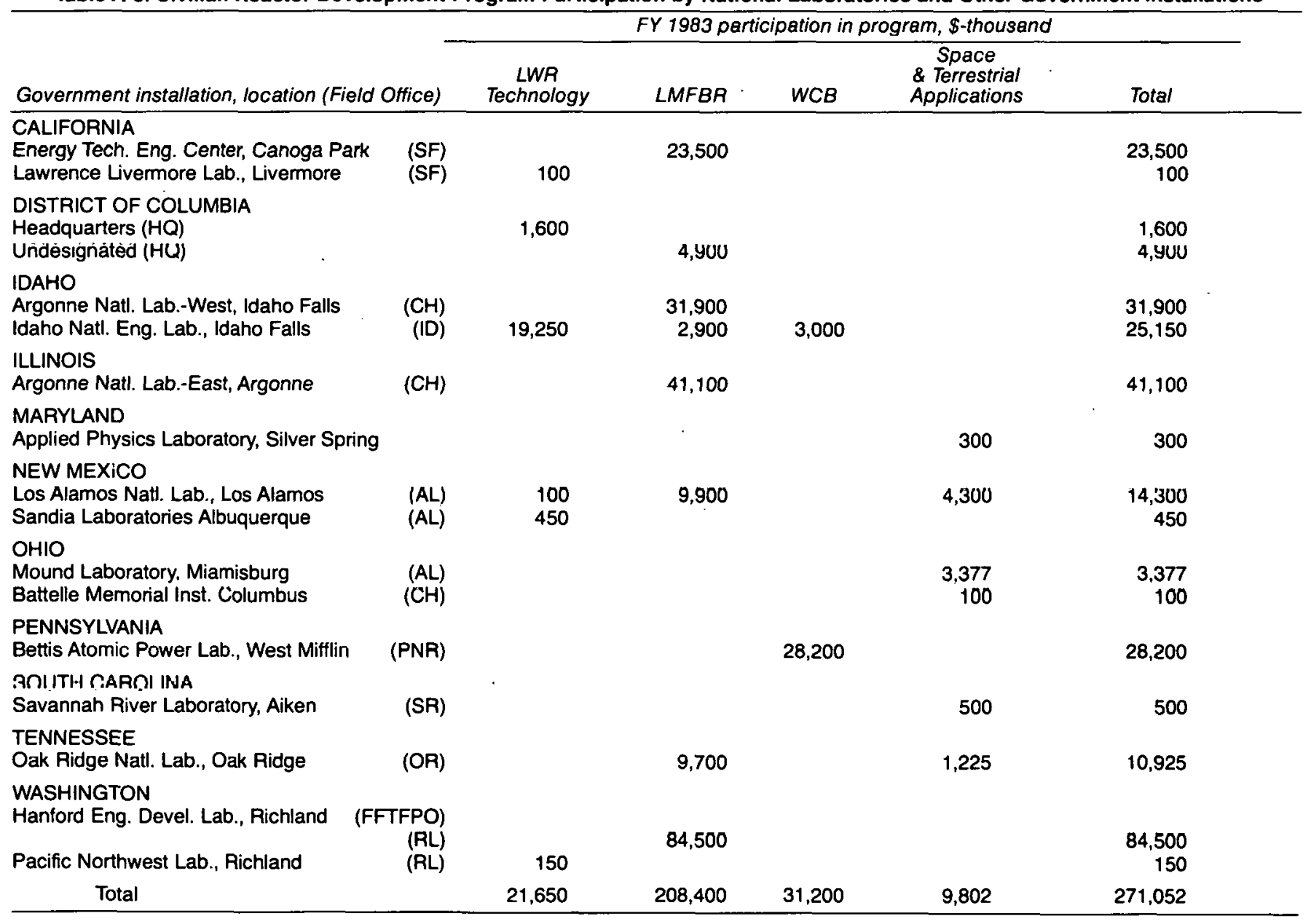




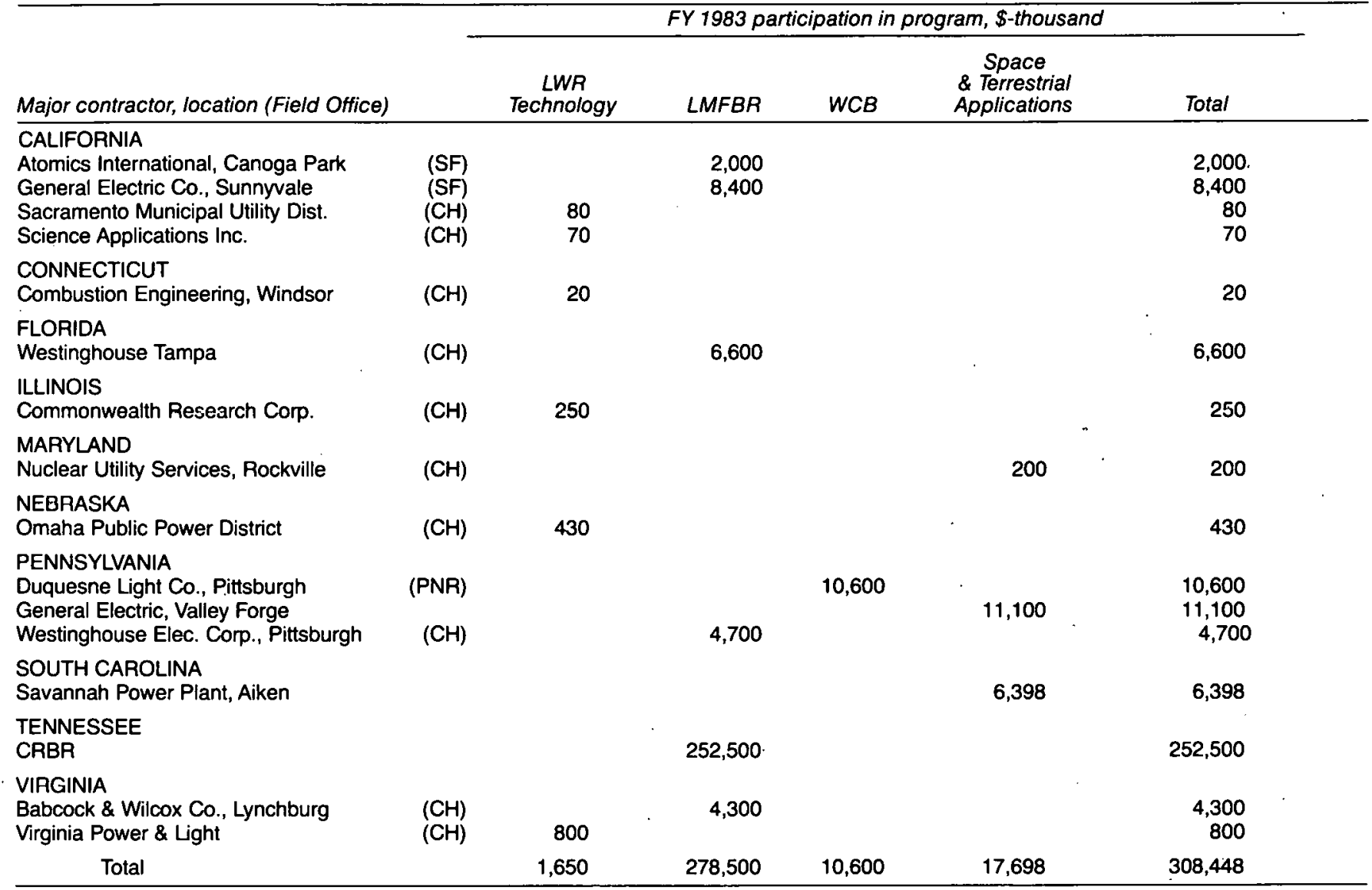

*Excluding contract operation of Government-owned installations.

Table D-7. University* Participation in Civilian Reactor Development Programs

\begin{tabular}{|c|c|c|c|c|c|}
\hline \multirow[b]{2}{*}{ Univerisily, lưaliun (Fielu Offlce) } & \multicolumn{5}{|c|}{ FY 1983 participation in program, \$-thousand } \\
\hline & $\begin{array}{l}\text { LWR } \\
\text { Tuch. }\end{array}$ & $\angle M F B A$ & WCB & $\begin{array}{l}\text { Space } \\
\text { \& Terr. } \\
\text { Appl. }\end{array}$ & Toral \\
\hline Total & 500 & & & & 500 \\
\hline
\end{tabular}

*Excluding contract operation of Government-owned installations. 


\section{APPENDIX B Program Definitions}

\subsection{FISSION ENERGY SYSTEM FUNDAMENTALS}

In a nuclear fission energy system, energy is produced by a nuclear reaction in which an atomic nucleus captures a neutron and fissions (splits) into two approximately equal parts liberating a large amount of energy and, generally, one or more neutrons. The atomic nuclei that fission most easily are certain isotopes of uranium and plutonium. These isotopes constitute the fissile fuel of a nuclear powerplant. The fuel may also contain a fertile material that, although not in itself fissionable, can be converted into fissile material in a nuclear reactor. The neutrons released by the fission of a nucleus may also initiate fissions in other fissile nuclei. Under conditions provided in a nuclear reactor plant, the fission process becomes selfsustaining and controllable.

Uranium, as found in nature, contains 0.7 percent of $\mathrm{U}-235,99.3$ percent of $U-238$, and a trace of U-234. The fuel loaded into an LWR reactor is enriched in its U-235 content to about 3.2 percent at one of the Governmentowned gaseous diffusion enrichment facilities. Enrichment removes almost 82 percent of the fertile U-238 originally mined before it ever reaches the reactor. These tailings of the enrichment process are stockpiled (still containing about 0.2 percent $U$-235) at the enrichment plant sites. These enrichment facilities will be augmented in the late 1980 s by a gaseous centrifuge enrichment plant. Other more advanced separation processes are under investigation.

The conversion ratio of a reactor is the ratio of the rate at which fissile material is bred to the rate at which it is consumed. A reactor may be classified either as a converter, in which more fissile material is consumed than is generated (conversion ratio less than one), or as a breeder, in which more fissile material is generated than is consumed (conversion ratio greater than one). Converters that are more efficient in fuel utilization than the standard, present day LWR on a once-through fuel cycle are termed improved or advanced converters.

Reactors may also be classified according to the predominant energy of the neutrons that induce fission. Fission neutrons are produced with a wide spectrum of energies; the average energy of freshly born neutrons is about one million electron volts. Before they are absorbed, the neutrons may collide with the nuclei of the reactor's coolant and structural materials, which reduces the neutron energies. The lightest-weight nuclei, such as the hydrogen in ordinary water, are most effective in reducing neutron energy. This process of slowing-down continues until the neutrons are captured or they reach thermal equilibrium with surrounding materials (about 0.025 electron volts at room temperature). Reactors such as LWRs, that operate with neutrons in this energy range, are termed thermal reactors. Those reactors that operate with relatively little slowing-down of neutrons are termed fast reactors, since the average energy of neutrons that are captured is high. The inherent nuclear properties of fertile materials make breeding more readily achievable in fast reactors.

In fission power systems, fuel ulilizalion is defined as the arnouril of usable enrergy oblained per unil of uranium mined. Generally, the higher the conversion ratio, the higher the fuel utilization. In the LWR once-through fuel cycle, only about 1 percent of the energy content of the mined uranium is utilized.

There are many fuel cycles that can be employed. In the once-through fuel cycle. fuel is loaded into the reactor. used until full-power operation is no longer practical and then discharged and disposed of safely. Unused fissile material, either that remaining from the original charge or that generated in the reactor, is not recovered from the discharged fuel. This cycle is shown schematically in Figure B-1. 


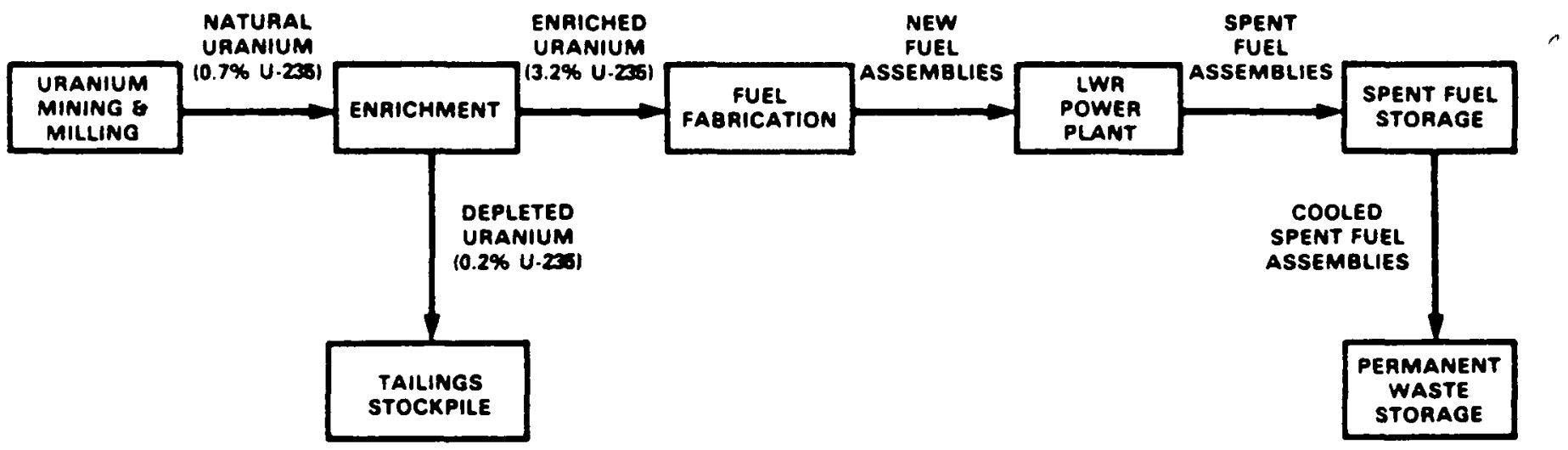

Figure B-1. LWR once-through fuel cycle

In the LWR system, the nuclear fission energy system in predominant use around the world today and, therefore, the reference system for comparative purposes, the fissile material is uranium-235 (U-235), and the fertile material is uranium-238 (U-238). Fuel that has been fabricated into large assemblies weighing several tons each is loaded into the reactor in an arrangement called a core, which enhances the fission reaction and permits its control. During reactor operation, fissile material is consumed. As operation proceeds, waste products of the fission process tend to poison or retard the process. The amount of fissile material decreases and the poisons build up until a point is reached at which the reaction can no longer be maintained. Then, even though the fuel still contains a significant amount of fissile material, it must be removed and replaced by new fuel assemblies. The spent fuel assemblies are removed to storage in large tanks of water awaiting permanent storage or disposal (for the once-through cycle), or reprocessing (see below).
There are several processes that can be employed to improve fuel utilization in converter reactors. One of these is uranium recycle, illustrated in Figure B-2. Here, the spent fuel assemblies, after an initial cooling period, are dissolved and the residual uranium, plutonium, and fission products are chemically separated in a reprocessing plant. The recovered uranium, containing about 0.8 percent $U$ 235 , is then passed to a fuel refabrication plant where it is mixed with new enriched uranium to bring its U-235 content up to the powerplant requirement of about 3.2 percent, refabricated into new assemblies, and returned to a reactor. The refabrication processes are about the same as those for new fuel except that the operations may be conducted using remote handling techniques because of the additional induced radioactivity accompanying the recovered uranium. Uranium recycle has the potential of improving fuel utilization by about 20 percent. However, no commercial reactors have yet been operated using recycled fuel.

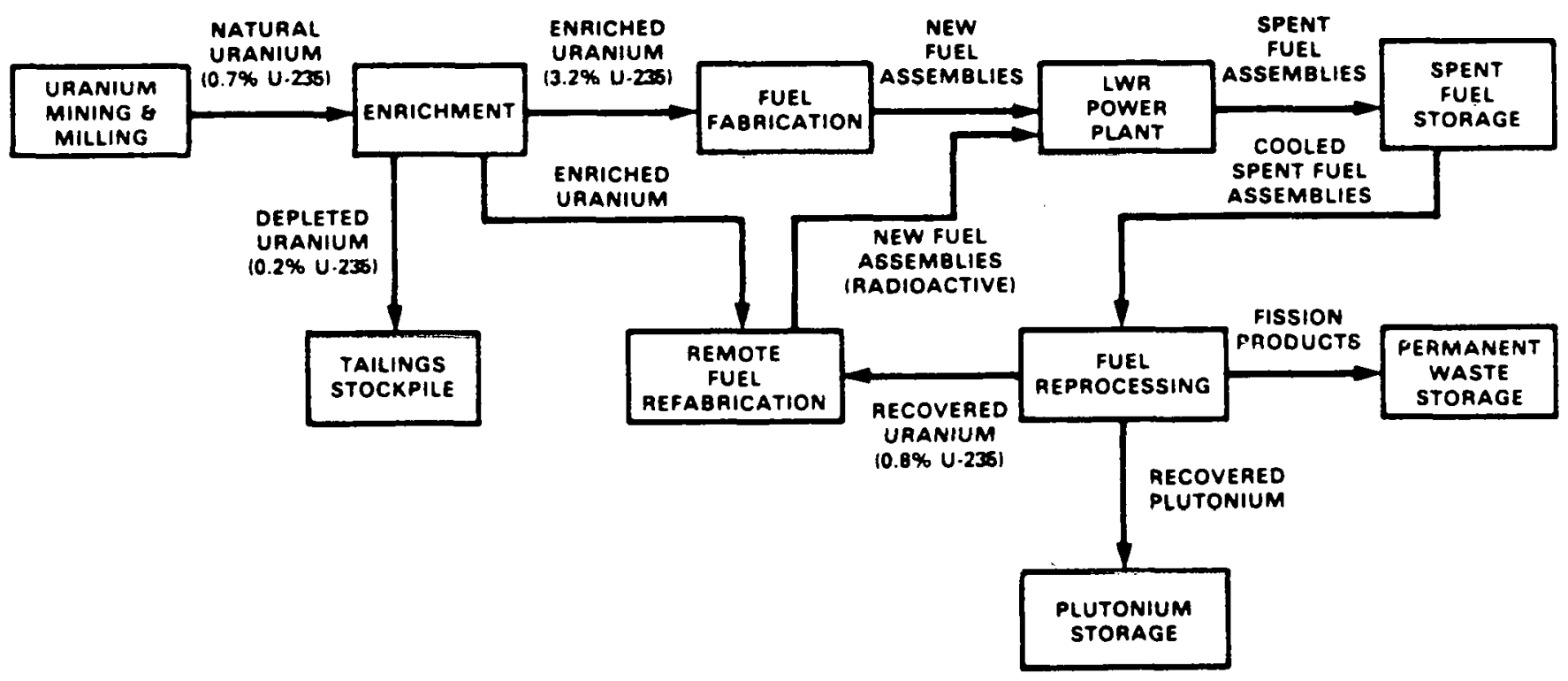

Figure B-2. LWR fuel cycle using uranium recycle. 
The plutonium, a fissile material that has been generated during reactor operation from $\mathrm{U}-238$ and separated during reprocessing, could also be recycled along with the uranium. However, because plutonium is more valuable as a fuel in fast breeder reactors and will be required for the initial fuel loadings in such reactors, prudent planning favors storing the plutonium for later breeder use rather than recycling it in converters. Thermal recycle, recycling both uranium and plutonium, has the potential for improving fuel utilization by about 35 percent. However, our commercial reactors have not yet operated using thermal recycle.

A thorium/uranium fuel cycle, such as might be used in an advanced converter, is shown in Figure B-3. Except for the addition of the thorium supply, it is generally similar to the LWR using recycle because reprocessing is required to recover and utilize the $\mathrm{U}-233$ generated from the fertile thorium. Since the conversion ratio is usually not greater than one, and since U-233 does not occur naturally in uranium ores, the recovered U-233 is supplemented with U-235 to obtain the proper fissile material fraction in the new tuel assemblies. This can be done by making some fuel assemblies with new U-235 and some with recovered $\mathrm{U}-233$, or the U-233 and supplemental U-235 can be mixed. Plutonium storage is indicated because some plutonium will always be formed from the U-238 fed to the reactor in conjunction with the U-235 makeup.

The uranium/plutonium fuel cycle for a fast breeder is illustrated in Figure B-4. In this case, since all fissile material requirements of the reactor are fulfilled by bred and recycled plutonium, no $U-235$ input is required. The fertile U-238 requirements can be met from the existing stockpiles of depleted uranium tailings from enrichment plants.

In a breeder reactor, the fuel discharged from the reactor contains more fissile material than the fuel initially charged. This fuel must be reprocessed to extract the fissile material for further use as reactor fuel. Fissile material in excess of that required to fuel the reactor in which it was produced can be withdrawn from the cycle and used in other reactors.

Table B-1 summarizes the characteristics of LWRs and other major types of power reactors.

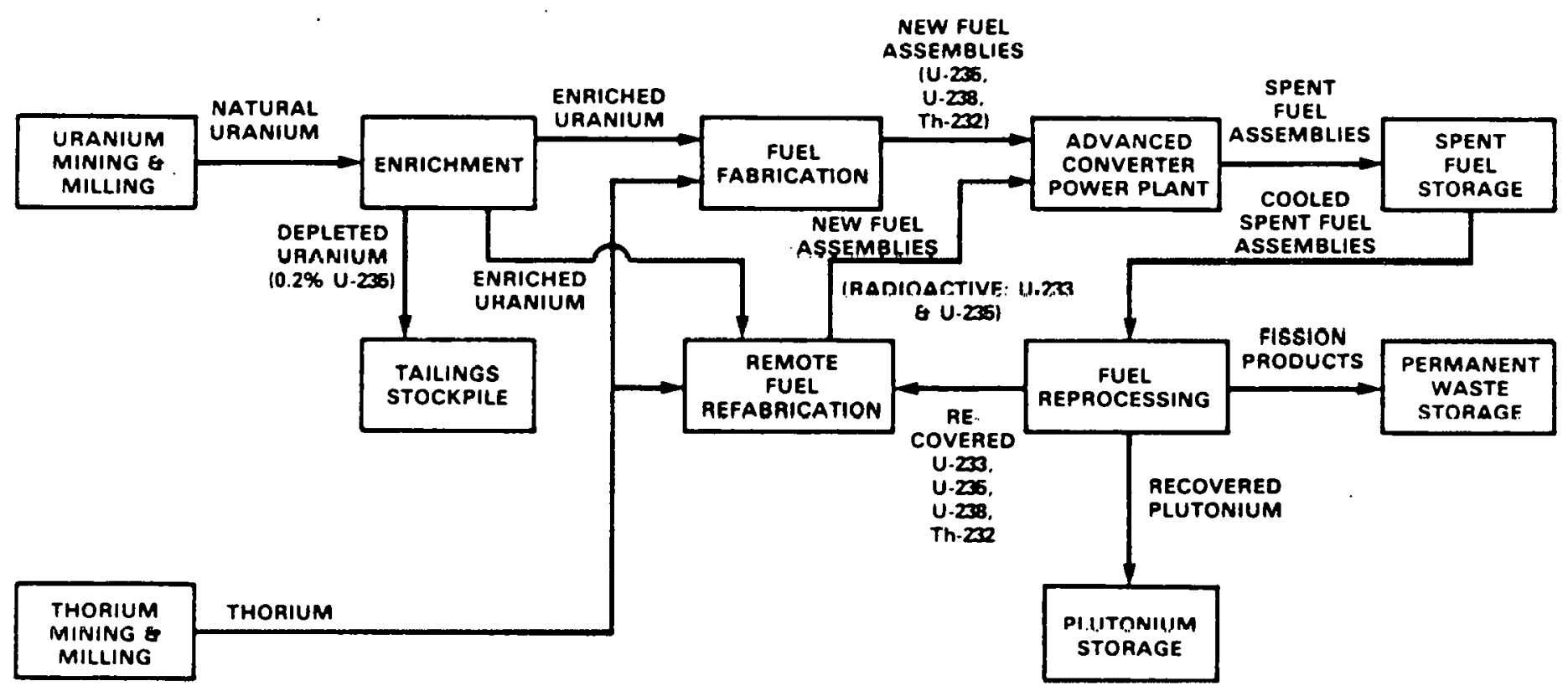

Figure B 3. Advanced converter using thorium/uranium fuel cycle 


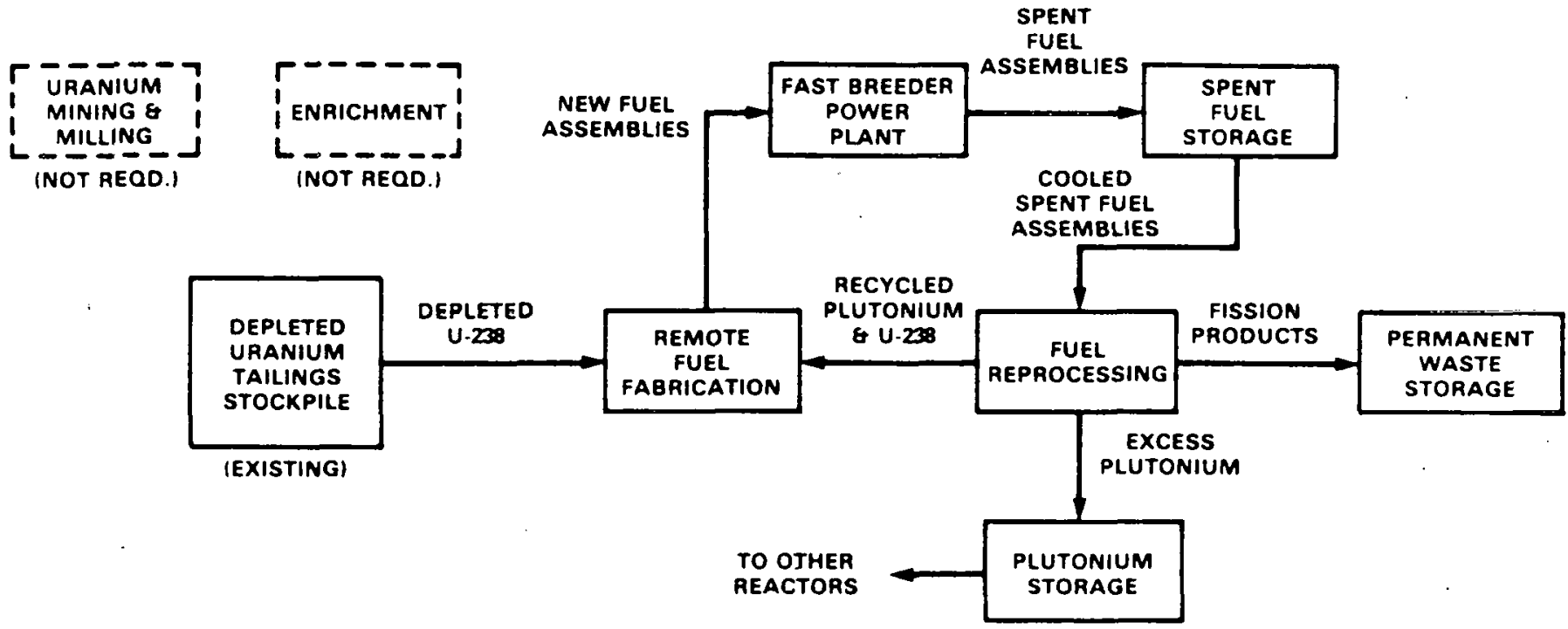

Figure B4. Fast breeder plutonium/uranium fuel cycle

Table B-1. Characteristics of Fission Reactor Systems

\begin{tabular}{|c|c|c|c|c|c|c|c|c|}
\hline \multirow[b]{3}{*}{ Reactor technology } & \multirow[b]{3}{*}{ Reactor type } & \multirow[b]{3}{*}{ Neutron } & \multirow[b]{3}{*}{$\begin{array}{c}\text { State of } \\
\text { development }\end{array}$} & \multirow[b]{3}{*}{$\begin{array}{l}\text { Existing U.S. } \\
\text { reactors }\end{array}$} & \multirow[b]{3}{*}{ Coolant } & \multicolumn{3}{|c|}{ Fuel cycle } \\
\hline & & & & & & \multicolumn{2}{|c|}{ Reactor loading } & \multirow{2}{*}{$\begin{array}{c}\text { Fissile } \\
\text { material } \\
\text { generated }\end{array}$} \\
\hline & & & & & & Fissle & Fertile & \\
\hline $\begin{array}{l}\text { LIGHT WATER BREEDER } \\
\text { REACTOR }\end{array}$ & Breeder & Thermal & Developmental & Shippingport & Water & U-233 & Th & U-233 \\
\hline $\begin{array}{l}\text { LIQUID METAL FAST } \\
\text { BREEDER REACTOR }\end{array}$ & Breeder & Fast & Developmental & EBR-II \& FFTF & Sodium & $\mathrm{Pu}$ & $U-238$ & $\mathrm{Pu}$ \\
\hline
\end{tabular}

\subsection{POWERPLANT FUNDAMENTALS}

The fundamental difference between types of steamelectric powerplants is the source of the heat. The mode of operation of each of these plants is also slightly different. In a nuclear plant, heat is produced by the fission process (see Section 1.0). In a fossil plant, heat is produced by a chemical reaction (combustion) of carbon and hydrogen (in oil, coal, or natural gas fuels) with oxygen (in air); fuel and air are continuously supplied to a firebox. In a geothermal plant, the source of heat is that stored in the earth's interior; heat is continuously extracted from water, steam or hot rock deep within the earth. In all of these types of steam-electric plants, the basic elements other than the source of heat are the same.

All steam-electric powerplants have at least the following basic elements:

- a boiler and source of heat

- a turbine

- an electric generator

- a condenser

- pumps and piping
In addition, depending upon the specific design details of a particular plant, there are numerous auxiliary and support systems that are necessary to monitor and control the basic elements or to provide essential services for operating and maintaining the plant.

The fundamentals of steam-electric powerplant operation are as follows: A source of heat causes water in a boiler to be changed into steam. The steam flows to a turbine where the energy of the steam causes the turbine to spin. An electric generator, connected to the turbine, produces electric power, which is delivered to consumers via transmission lines. A steam-water mixture is exhausted from the turbine to a condenser which condenses it to water. A pump feeds the water back to the boiler. The boiler, turbine, condenser and pump are connected by piping. The cycle (heat in, electricity and heat out) continues as the water/steam circulates through the loop.

There are two common designs of nuclear plants currently in use in the United States. In the simplest, the reactor vessel and the boiler are one and the same. Water enters the fuel region and steam leaves. This design is called the boiling water reactor (BWR). In the other design, 
boiling occurs in a separate vessel called a steam generator. The heat is supplied, or transferred, to the steam generator by an entirely different and isolated water system called the primary system. The primary system consists of a reactor vessel, pump, and piping and is pressurized to prevent boiling in the system. This design is called the pressurized water reactor (PWR). This is the basic type also used to power our country's nuclear ships.

Fluids other than water may be used in the primary system of a nuclear powerplant. Helium is used in gascooled reactors and sodium is used in the liquid metal fast breeder reactor. Other countries have designed and built nuclear plants using heavy water (Canada) or carbon dioxide (United Kingdom) in the primary system. However, the fluid predominantly used in the primary systems of nuclear plants around the world is light (ordinary) water. The term "light water reactor" (LWR) is commonly applied to both the BWR and PWR designs.

\subsection{DEFINITIONS}

Acquisition Strategy. Part of DOE's Energy System Acquisition Project Plan (ESAPP), the Acquisition Strategy details the resource requirements, methods of solicitation and contractual arrangements, cost participation or sharing, business risk, organizations involved by type and number, and identification of performers' responsibilities.

Advanced Converter Reactor (ACR). A reactor system that provides better uranium fuel utilization than that obtained in present commercial Light Water Reactors (LWRs), but not as good as a breeder reactor.

Applied Research. Systematic study directed toward fuller scientific knowledge or understanding for direct use in fulfilling specific energy requirements. More generally, applied research is defined as work to solve problems in the physical, biological, behavioral, social, and engineering sciences that have no clear-cut applicability to specitic projects - it includes the technical means of obtaining the knowledge, understanding, and solution.

Basic Research. Systematic, fundamental study directed toward fuller scientific knowledge or understanding of subjects bearing on national energy needs. More generally, basic research is defined as work to increase knowledge and the quantitative understanding of natural phenomena and the environment.

Blanket. A layer of fertile material surrounding the driver core of a breeder reactor. See also "Fertile Material" and "Seed and Blanket."

Breeder Reactor. A reactor that creates more fissile material than it consumes; the process by which this occurs is known as breeding. The new fissile material is created by capture of fission-generated neutrons in fertile material.

Commercial Demonstration Plants. The purposes of commercial demonstration plants are: (1) to resolve commercial investment uncertainties by establishing the actual economic factors, environmental feasibility, socioeconomic impact, capital and resource requirements, and constraints, and (2) to encourage creation of a viable industry using these technologies. They have an output of about three to five times that of Demonstration Plants, and they demonstrate the viability of a facility or process to compete commercially.

Commercialization. The process of bringing a system or technology to commercial reality rather than demonstrating technical feasibility. The commercialization phase is characterized by the fact that: (1) "scale-up" problems have already been overcome; (2) economics of fabrication and operation are understood; (3) public acceptance, institutional, and environmental issues have been resolved; and (4) commercial interest arises. The path to commercialization proceeds from basic research through applied research, exploratory development, technology development, engineering development, and finally demonstration within the environment of production operations.

Conversion Ratio. The ratio of the atoms of fissile isotopes produced to those consumed in a reactor. In a converter reactor this ratio is less than 1 ; in a breeder reactor it is greater than 1.

Demonstration. Verification of economic and environmental viability for commercial application, through design, construction, test, and evaluation of large-scale energy systems in operational circumstances. The final engineering design, assembly, test and evaluation of fullscale energy systems aims to provide directly applicable experience in an operational environment. Demonstration projects are intended to (a) overcome "scale-up" problems; (b) contribute to the understanding of the economics of fabrication and operation; and (c) resolve other questions such as public acceptance, institutional and environmental issues. Preparation of suitable environmental impact statements is included in this category.

Demonstration Plants. Plants intended to demonstrate and validate cconomic, environmental, and productive capacity of a reactor technology. Demonstration plants are still developmental in the sense that technological scale-up problems could occur and require engineering modifications, but the risk is much lower because the plant production process was developed and tested at the pilot stage.

Depleted Uraniuim. Uran ium liaviny a luwer cuncerltration of the uranium-235 isotope than that found in natural urarium, i.e., uranlumr contalnlriy less than 0.7 I percent $U$ 235.

Development Phases. These are considered to be: (1) basic research, (2) applied research, (3) exploratory development, (4) technology development, (5) engineering development, (6) demonstration, and (7) commercialization, production, and operation.

Engineering Development. Systematic use of the knowledge and understanding gained from research and technology development to achieve the detailed design and construction of energy-system prototypes and pilot plants, and their testing for performance, producibility and reliability. 'Engineering development may concern itself with processes, preproduction components, equipment, subsystems, or systems. This category also includes major 
system test facilities directed toward specific project development and the preparation of appropriate environmental impact statements.

Enriched Uranium. Uranium having a higher concentration of the uranium-235 isotope than found in natural uranium, i.e., uranium containing more than 0.71 percent U-235.

Exploratory Development. The assessment of technological options that have gone through the stages of basic and applied research. The work focuses the energy system options to identify technological potential, risks, resource requirements, environmental issues, and requirements for accelerated funding. The work is guided by the principle that it should lead ultimately to a particular application or product. Exploratory development can cut across several scientific disciplines and is intended to explore possible innovation in a particular area of one or more energy technologies.

Fertile Material. Normally nonfissile material that can, through the absorption of neutrons, be transmuted into fissile material. Examples are uranium-238 and thorium.

Fissile Material. Nuclear fuel that is capable of sustaining a nuclear chain reaction. Examples of fissile material are uranium-233, uranium-235, and plutonium-239.

Heavy Water. A compound chemically identical to water, composed of oxygen and the isotope of hydrogen of atomic weight 2; deuterium oxide, $D^{2} O$.

High-level Wastes. By-products of the reprocessing of spent nuclear fuels, or in the case of the once-through fuel cycle, the spent fuels themselves. High-level waste from reprocessing contains most of the fission products and those actinides not carried with the uranium and plutonium.

Life-cycle Cost. The total of the direct, indirect, recurring, nonrecurring, and other related costs incurred, or estimated to be incurred, in the design, development, production, operation, maintenance, and support of a major system over its anticipated useful life span.

Light Water. Ordinary water $\left(\mathrm{H}^{2} \mathrm{O}\right)$, as distinguished from heavy water $\left(D^{2} O\right)$.

Low-level Wastes. Radioactive wastes containing less than 10 nanocuries of alpha-emitting transuranic elements and uranium-233 per gram. Their radioactivity can be concentrated and thus become dangerous, but it is usually barely above background levels. Low-level wastes are routinely buried in shallow repositories.

Major System. That combination of elements that will function together to produce the capabilities required to fulfill a mission need. The elements may include, for example, hardware, equipment, software, construction, other improvements, or real property. Major system acquisition projects are those projects that: (1) are directed at and are critical to fulfilling a DOE mission, (2) entail the allocation of relatlvely large resources, and (3) warrant special management attention.

Natural Uranium. The naturally occurring form of uranium--it contains 0.71 percent fissile uranium-235, a trace of uranium-234, and the remainder is uranium-238.
Nuclear Wastes. Wastes generated from nuclear processes. The four kinds of nuclear wastes are: high-level, transuranic (TRU), low-level, and uranium mine and mill tailings.

Pilot Plant. The purpose of a pilot plant is to establish the feasibility of an integrated process by combining commercial-type (not commercial-size) components into a small model plant to test and evaluate the critical scale-up parameters and to acquire engineering data needed to assess economic feasibility and design a nearer-commercial-size plant. Pilot plants are usually short lived and are the first scaleup facility to produce enough end product to permit product testing and refinement.

Prebreeder Core. A reactor core designed with a high conversion ratio (but less than 1.0) for the purpose of transmuting fertile material to fissile material for subsequent use in a breeder reactor.

Proliferation. The acquisition of nuclear weapons by a non-nuclear state.

Reflector. A layer of material that immediately surrounds a reactor core and scatters back (reflects), into the core, or into fertile material, neutrons that would otherwise escape. These neutrons can then cause additional fission or create fissile material, thus improving the neutron economy of the reactor. Common reflector materials are graphite, water, and beryllium.

Seed and Blanket. A reactor core that includes a relatively small volume of material with a high content of fissile material (the seed) surrounded by a much larger volume of material with a high content of fertile material (the blanket). As a result of fissions in the seed, neutrons are supplied to the blanket where new fissile fuel is produced and more fission takes place. In this way, the blanket is made to furnish a substantial fraction of the total power of the reactor.

Technology Development. Systematic use of the knowledge and understanding gained from research to achieve technical feasibility and to gauge the economic and environmental potential of energy concepts, processes, materials, devices, methods, and subsystems. More generally, technology development comprises development of engineering technologies, subsystems, planning and analysis studies, energy system concept formulation, comparison of alternative concepts, and development and test of laboratory-scale engineering feasibility models. This includes demonstration by experiment of alternative system concepts as well as preliminary studies encompassing system analysis, trade-offs, preliminary cost-benefit studies, planning, and the programming of environmental studies.

Thoria. Thorium oxide $\left(\mathrm{ThO}^{2}\right)$.

Transuranic (TRU) Wastes. Materials containing more than 10 nanocuries of transuranic activity per gram. These come predominantly from spent fuel reprocessing activities and from the fabrication or processing of plutonium in the production of either nuclear weapons or fuel rods for reactors.

Urania. Uranium oxide $\left(\mathrm{UO}^{2}\right)$.

Uranium Mill Tailings. Wastes resulting from extrac- 
tion of uranium from ore at uranium mills. The radioactivity is of low concentration, but concern arises because many piles of tailings are unstabilized and unprotected from spreading to adjacent property. 


\section{APPENDIX C \\ Program Acronyms and Letter Designations}

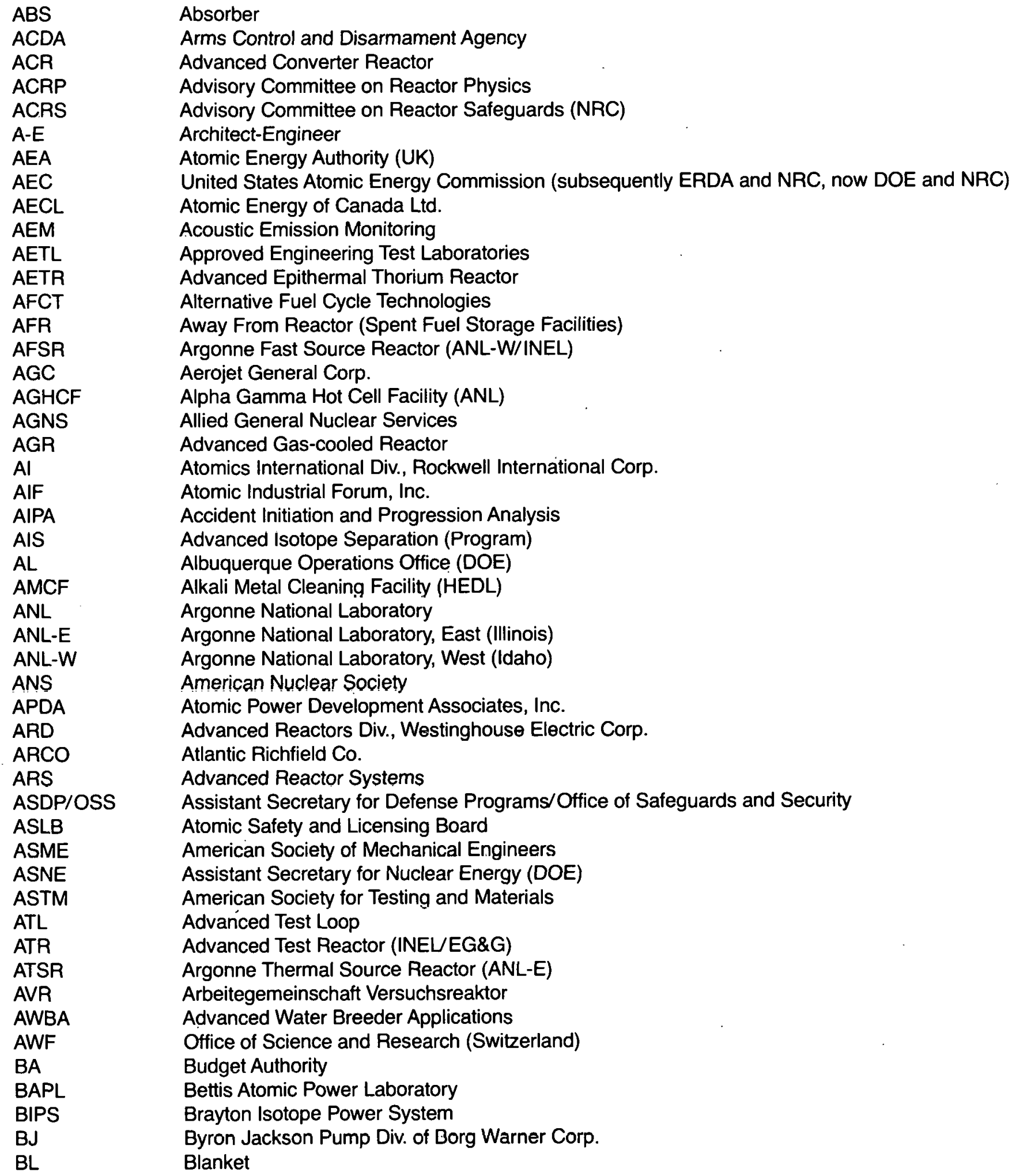




\begin{tabular}{|c|c|}
\hline BLTC & Bottom Loading Transfer Cask \\
\hline BMFT & Federal Ministry for Research \& Technology (FRG) \\
\hline BMI & Battelle Memorial Institute \\
\hline $\mathrm{BN}-350,600$ & Russian LMFBRs \\
\hline BNAF & Breeding Non-Destructive Assay Facility \\
\hline BNFP & Barnwell Nuclear Fuel Plant \\
\hline BNFS & Barnwell Nuclear Fuel Services \\
\hline BNL & Brookhaven National Laboratory \\
\hline BO & Budget Outlay \\
\hline BOM & Bureau of Mines (U.S. Dept. of Interior) \\
\hline BOP & Balance of Plant \\
\hline BOR-60 & Russian LMFBR \\
\hline BPV & Boiler and Pressure Vessel (Codes developed by the ASME) \\
\hline BR-1,-2,-5,-10 & Russian LMFBRs \\
\hline BR-2 & Belgian test reactor \\
\hline BRC & B̈reeder Reactor Ċorp. \\
\hline B\&W & Babcock and Wilcox Co. \\
\hline$B \& R$ & Burns \& Roee. İnc. \\
\hline BWR & Boiling Water Reactor \\
\hline CACS & Core Auxiliary Cooling System \\
\hline CANDU & Canadian-Deuterium-Uranium Reactor \\
\hline CDA & Core Disruptive Accident \\
\hline CDF & Component Development Facility \\
\hline CDFR & Commercial Demonstration Fast Reactors (UKAEA) \\
\hline CDFSAR & Conceptual Design Final Safety Analysis Report \\
\hline CDS & Conceptual Design Study (for LMFBR developmental plant) \\
\hline CDSAR & Conceptual Design Safety Analysis Report \\
\hline CE & Combustion Engineering, Inc. \\
\hline CE & Commonwealth Edison, Co. \\
\hline CEA & Commissariat a l'Energie Atomique (France) \\
\hline CEL & Carbon Equllibrlum Loop (WARD) \\
\hline CERN & European Organization for Nuclear Research \\
\hline CESNEF & Centro Studi Nucleari 'Enrico Fermi' (Italy) \\
\hline CFR & Commercial Fast Reactor (U.K.) \\
\hline CFRP & Consolidated Fuel Reprocessing Program \\
\hline CFTL & Core Flow Test Loop \\
\hline CHCF & Component Handling and Cleaning Facility (ETEC) \\
\hline CIP & Cascade Improvement Program \\
\hline CIVEX & Civiliarı Purex Prucesss \\
\hline CLEM & Closed Loop Ex-Vessel Machine (FFTF) \\
\hline CLIRA & Closed Loop In-Reactor Assembly (FFTF) \\
\hline CMM & Coro Mcohanioal Moclcup (HEDL) \\
\hline CNEN & Comitate Nazionale per l'Energia Nucleare (Italy) \\
\hline CNWV & Commercial Nuclear Waste Vitrification (Demonstration) \\
\hline CORO & Chicago Operations and Regional Offfice \\
\hline CP-5 & Chicago Pile No. 5 (ANL-E) \\
\hline CRBR & Clinch River Breeder Reactor \\
\hline CRBRP & Clinch River Breeder Reactor Plant \\
\hline CRCTA & Composite Reactor Component Test Activity (HEDL) \\
\hline CRDM & Control-Rod Drive Mechanism \\
\hline CREDO & Centralized Reliability Data Bank \\
\hline CRM & Core Restraint Mechanism \\
\hline CRT & Cathode-ray Tube \\
\hline CSDD & Conceptual System Design Description \\
\hline Cs & Cesium \\
\hline CSTF & Containment Systems Test Facility \\
\hline CUP & Cascade Uprating Program \\
\hline CY & Calendar Year \\
\hline DAP & Data Acquisition Program (TMI) \\
\hline
\end{tabular}




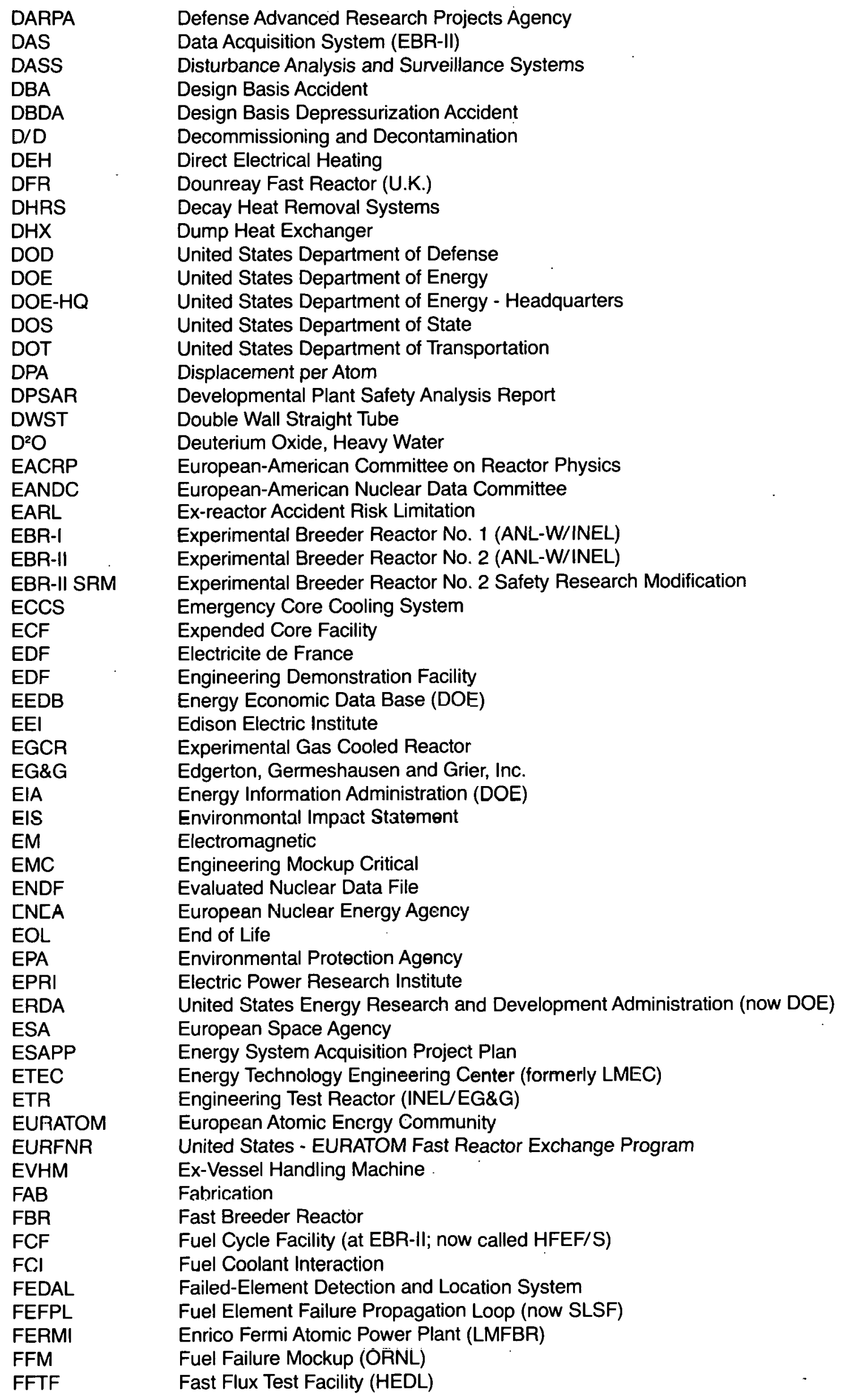




\begin{tabular}{|c|c|}
\hline $\begin{array}{l}\text { FIV } \\
\text { FMEF }\end{array}$ & $\begin{array}{l}\text { Flow-Induced Vibration } \\
\text { Fuels and Materials Examination Facility (HEDL) }\end{array}$ \\
\hline FMSR & Fast-Mixed Spectrum Reactor \\
\hline FNAL & Fermi National Accelerator Laboratory (formerly National Accelerator Laboratory) \\
\hline FNG & Fast Neutron Generator (ANL) \\
\hline FNR & Ford Nuclear Reactor \\
\hline FOTA & Fuels Open Test Assembly (FFTF) \\
\hline FRAD & Fuel Refabrication and Development Program \\
\hline FRG & Federal Republic of Germany (West Germany) \\
\hline FSA & Fueled Sphere Assembly \\
\hline FSAR & Final Safety Analysis Report \\
\hline FSF & Fuel Storage Facility (HEDL) \\
\hline FSS & Full-Scale Shear \\
\hline FSV & Fort St. Vrain, United States 330-MWe HTGR plant \\
\hline FTR & Fast Test Reactor (now FFTF) (HEDL) \\
\hline FWC & Foster-Wheeler Corp. \\
\hline FY & Fiscal Year \\
\hline GA & General Atomic Cọ. (Gụlt/ Șhell) \\
\hline GATR & General Atomic Test Reactor \\
\hline GBRA & Gae-Coolod Broodor Roactor Assooiation (Europcan) \\
\hline GCFR & Gas Cooled Fast Reactor \\
\hline GCHWR & Gas Cooled Heavy Water Reactor \\
\hline GCR & Gas Cooled Reactor \\
\hline GCRA & Gas Cooled Reactor Associates (HTGR utility group) \\
\hline GCTR & Gas Cooled Thermal Reactor \\
\hline GCUA & Gas Cooled Reactor Umbrella Agreement (international agreement on gas cooled reactors) \\
\hline GDS & Ground Demonstration System (isotopic generator, Space Program) \\
\hline GE & General Electric Co. \\
\hline GEARSD & General Electric Advanced Reactor Systems Division \\
\hline GEIS & Generic Environmental Impact Statement \\
\hline GE-NED & General Electric Co. Nuclear Engineering Div. \\
\hline GETR & General Electric Test Reactor (GE) \\
\hline GPE & General Purpose Equipment \\
\hline GPF & General Purpose Facility of the Integrated Equipment Test (IET) Facility \\
\hline GPHS & General Purpose Heat Source (Solar Polar Mission, Space Program) \\
\hline GPL & General Purpose Loop (WARD) \\
\hline GPM & Gallons Per Minute \\
\hline GPP & General Plant Projects \\
\hline GPU & General Public Utilities \\
\hline GRIST-2 & Gas Reactor In-Pile Safety Test \\
\hline $\bar{G} \bar{R} \bar{T}$ & Gulf Radiation Technology, Inc. \\
\hline GT-HTGR & Gas Turbine High Temperature Gas Cooled Reactor \\
\hline GWe & Gigawatts electric \\
\hline $\mathrm{HBA}$ & Helium Breeder Associates (GCFR utility group) \\
\hline HCDA & Hypothetical Core Dișruptive Accident \\
\hline $\mathrm{HCM}$ & Hydraulic Core Mockup (HEDL) \\
\hline HCTF & Helium Component Test Facility \\
\hline HEDL & Hanford Engineering Development Laboratory \\
\hline HEF & Hot Experimental Facility (ORNL) \\
\hline HEFA & Highly Enriched Fuel Assembly \\
\hline HEPA & High-Efficiency Particulate Air (Filter) \\
\hline HETF & Hot Engineering Test Facility \\
\hline HEU & Highly Enriched Uranium \\
\hline HFEF & Hot Fuel Examination Facility (ANL-W/INEL) \\
\hline HFEF/N & HFEF-North (ANL-W/INEL) \\
\hline $\mathrm{HFEF} / \mathrm{S}$ & HFEF-South (formerly FCF) (ANL-W/INEL) \\
\hline HFIR & High Flux Isotope Reactor (ORNL) \\
\hline HFR & High Flux Reactor (Netherlands) \\
\hline $\mathrm{HHT}$ & German direct-cycle HTGR program \\
\hline
\end{tabular}




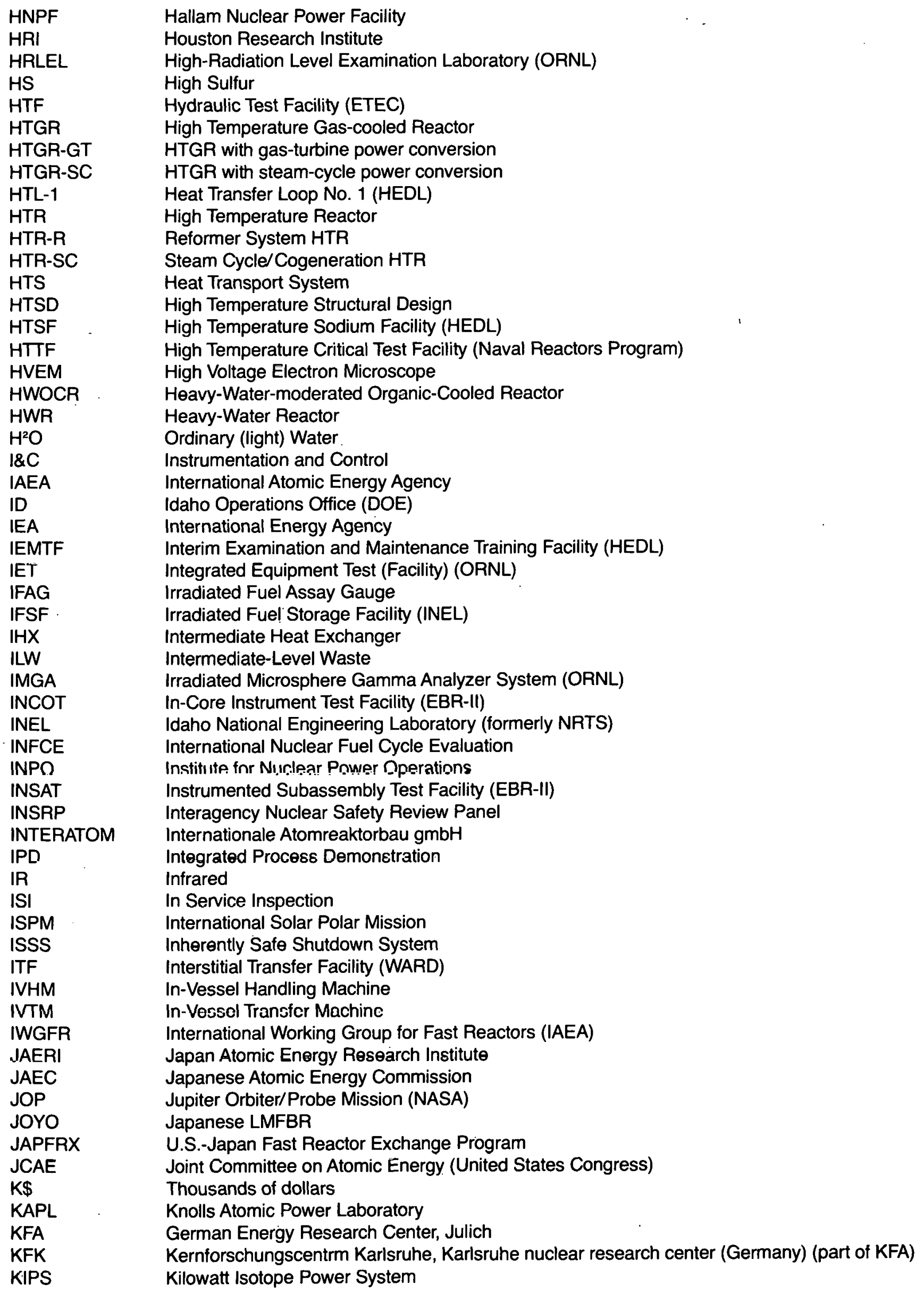




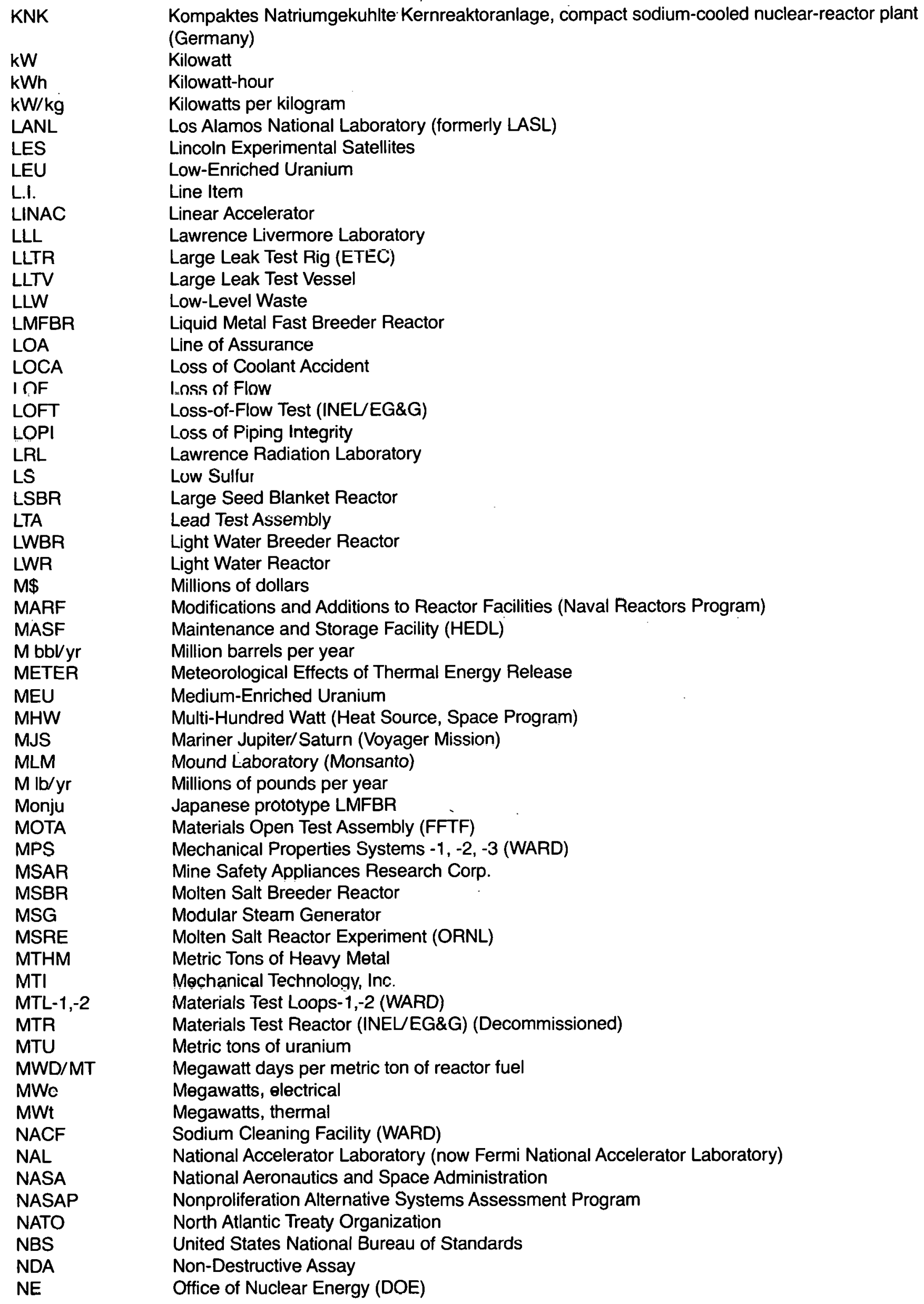

MLM

$\mathrm{Mlb} / \mathrm{yr}$

Monju

MOTA

MPS

MSAR

MSBR

MSG

MSRE

MTHM

MTI

MTL-1,-2

MTR

MTU

MWD/MT

MWo

MWt

NACF

NAL

NASA

NASAP

NATO

NBS

NDA

NE

Line Item

Linear Accelerator

Lawrence Livermore Laboratory

Large Leak Test Rig (ETEC)

Large Leak Test Vessel

Low-Level Waste

Liquid Metal Fast Breeder Reactor

Line of Assurance

Loss of Coolant Accident

Inss of Flow

Loss-of-Flow Test (INELEG\&G)

Loss of Piping Integrity

Lawrence Radiation Laboratory

Luw Sulfur

Large Seed Blanket Reactor

Lead Test Assembly

Light Water Breeder Reactor

Light Water Reactor

Millions of dollars

Modifications and Additions to Reactor Facilities (Naval Reactors Program)

Maintenance and Storage Facility (HEDL)

Million barrels per year

Meteorological Effects of Thermal Energy Release

Medium-Enriched Uranium

Multi-Hundred Watt (Heat Source, Space Program)

Mariner Jupiter/Saturn (Voyager Mission)

Mound Laboratory (Monsanto)

Millions of pounds per year

Japanese prototype LMFBR

Materials Open Test Assembly (FFTF)

Mechanical Properties Systems -1, -2, -3 (WARD)

Mine Safety Appliances Research Corp.

Molten Salt Breeder Reactor

Modular Steam Generator

Molten Salt Reactor Experiment (ORNL)

Metric Tons of Heavy Metal

Mẹchanical Technology, Inc.

Materials Test Loops-1,-2 (WARD)

Materials Test Reactor (INELEG\&G) (Decommissioned)

Metric tons of uranium

Megawatt days per metric ton of reactor fuel

Megawatts, electrical

Megawatts, thermal

Sodium Cleaning Facility (WARD)

National Accelerator Laboratory (now Fermi National Accelerator Laboratory)

National Aeronautics and Space Administration

Nonproliferation Alternative Systems Assessment Program

North Atlantic Treaty Organization

United States National Bureau of Standards

Non-Destructive Assay

Office of Nuclear Energy (DOE) 


\begin{tabular}{|c|c|}
\hline NEA & Nuclear Energy Agency (OECD) \\
\hline NEN & Deputy Assistant Secretary for Nuclear Reactor Programs (DOE) \\
\hline NEP & National Energy Plan \\
\hline NERVA & Nuclear Engine for Rocket Vehicle Application \\
\hline NFS & Nuclear Fuel Services, Inc. \\
\hline NOAA & National Oceanic and Atmospheric Administration \\
\hline NPD & Division of Nuclear Power Development (DOE) \\
\hline NPSH & Net Positive Suction Head \\
\hline NRC & United States Nuclear Regulatory Commission \\
\hline NRF & Neutron Radiography Facility (HEDL) \\
\hline NRL & Naval Research Laboratory \\
\hline NRTS & National Reactor Testing Station (now INEL) \\
\hline NSAC & Nuclear Safety Analysis Center \\
\hline NSMH & Nuclear Systems Materials Handbook \\
\hline NSSS & Nuclear Steam Supply System \\
\hline NURE & National Uranium Resources Evaluation \\
\hline NYSERDA & New York Energy Research and Development Authority (formerly NYARDA) \\
\hline OECD & Organization for Economic Cooperation and Development \\
\hline OER & Office of Energy Research (DOE) \\
\hline OPERA & Out-of-Pile Expulsion and Reentry Apparatus (ANL-E) \\
\hline ORELA & Oak Ridge Electron Linear Accelerator (ORNL) \\
\hline ORNL & Oak Ridge National Laboratory \\
\hline OR & Oak Ridge Operations Office (DOE) \\
\hline ORR & Oak Ridge Research Reactor (ORNL) \\
\hline ORRDACS & Oak Ridge Reactor Data Acquisition System \\
\hline OSHA & Occupational Safety and Health Agency \\
\hline OTA & Open-Loop Test Assemblies (FFTF) \\
\hline PAHR & Post-Accident Heat Removal \\
\hline PAL & Prototype Applications Loop (HEDL) \\
\hline PBF & Power Burst Facility (INELEG\&G) \\
\hline $\mathrm{PCl}$ & Pellet-Clad Interaction \\
\hline PCL & Partial Core Loading \\
\hline PCML & Plutonium Critical Mass Laboratory (PNL) \\
\hline PCR & Primary Control Rod \\
\hline PCRS & Primary Control Rod System \\
\hline PCHV & Prestressed Concrete Reactor Vessel \\
\hline PCTF & Plant Component Test Facility \\
\hline PDLP & Program Definition and Licensing Phase \\
\hline PDU & Process Development Unit \\
\hline PEC & Prova Elementi di Combustible, fuel-element test reactor (Italy) \\
\hline PEF & Plutonium Experimental Facility (SRL) \\
\hline PFR & Prototype Fast Reactor (U.K.) \\
\hline Phenix & French LMFBR demonstration plant \\
\hline PHWR & Pressurized Heavy Water Reactor \\
\hline PICS & Post-Impact Containment Shell \\
\hline PLFFF & Pilot-Line Fuel Fabrication Facility \\
\hline PISA & Post-Impact Shell Assembly \\
\hline PLBR & Prototype Large Breeder Reactor \\
\hline PMC & Project Management Corp. \\
\hline PNC & Power Reactor and Nuclear Fuel Development Corp. (Japan) \\
\hline PNL & Pacific Northwest Laboratory (Battelle) \\
\hline PNP & German process heat program \\
\hline PNR & Pittsburgh Naval Reactors Office (DOE) \\
\hline PO & Project Office \\
\hline POB & Proof of Breeding \\
\hline PNL & Pacific Northwest Laboratory (Battelle) \\
\hline PNP & German process heat program \\
\hline PNR & Pittsburgh Naval Roaotor3 Office (DOE) \\
\hline PO & Project Office \\
\hline
\end{tabular}




\begin{tabular}{|c|c|}
\hline $\begin{array}{l}\text { POB } \\
\text { PPBS }\end{array}$ & $\begin{array}{l}\text { Proof of Breeding } \\
\text { Planning, Programming and Budget System }\end{array}$ \\
\hline PPS & Plant Protection System \\
\hline PRCCS & Program Reporting and Change Control System \\
\hline PRDC & Power Reactor Development Co. \\
\hline PSAR & Preliminary Safety Analysis Report \\
\hline $\mathrm{Pu}$ & Plutonium \\
\hline PuFF & Plutonium Fuel Fabrication Facility (SRL) \\
\hline PWR & Pressurized-Water-cooled Reactor \\
\hline QA & Quality Assurance \\
\hline R\&D & Research and Development \\
\hline RAPSODIE & French experimental LMFBR \\
\hline RBCB & Run Beyond Clad Breach \\
\hline $\mathrm{RCB}$ & Reactor Containment Building \\
\hline RD\&D & Research, Development and Demonstration \\
\hline RDT & $\begin{array}{l}\text { Reactor Development and Technology (tormer AEC Divislon and name used for standards } \\
\text { developed by that Division.) }\end{array}$ \\
\hline RERTR & Redured-Enrichment Research and Iest Reactor (Programi) \\
\hline REU & Reduced Enrichment Uranium \\
\hline RFP & Request for proposal \\
\hline RFREPP & Remote Fuels Refabrication Engineering Pilot Plant \\
\hline RINSC & Rhode Island Nuclear Science Center \\
\hline RL & Richland (Washington) Operations Office (DOE) \\
\hline RM & Reactor Manufacturer \\
\hline RMEF & Remote Maintenance Evaluation Facility (HEDL) \\
\hline RML & Radiometallurgy Laboratory (HEDL) \\
\hline ROMD & Remote Operating and Maintenance Demonstration (ORNL) \\
\hline RPD & Reactor Program Division \\
\hline RRT & Division of Reactor Research and Technology (DOE) \\
\hline RSCL & Radioactive Sodium Chemistry Loop (EBR-II) \\
\hline RSS & Reactor Shutdown System \\
\hline RTG & Radioisotope Thermoelectric Generator \\
\hline RV & Reactor Vessel \\
\hline S\&W & Stone \& Webster, Inc. \\
\hline S/A & Subassembly \\
\hline SACRD & Safety Analysis Computerized Reactor Data Bank \\
\hline SAEA & Southwest Alomic Energy Associates \\
\hline SAF & Secure Automated Fabrication (formerly ZRFF) \\
\hline SAl & Science Appllcations, Inc. \\
\hline SAN & San Francisco Operations Office (DOE) \\
\hline SAPS & Shippingport Atomic Power Station \\
\hline SAR & Gafety Analyzir Report \\
\hline SAREF & Safety Research Experiment Facilities (formerly STF) \\
\hline SASS & Self-Activated Shutdown System \\
\hline SASS-ACEA & Self-Activated Shutdown System - Articulated Control Assembly \\
\hline SASS-FC & Self-Activated Shutdown System - Fluidic Control \\
\hline SASS-HAB & Self-Activated Shutdown System - Hydraulic-Supported Absorber Balls \\
\hline SCAE & State Committee for the Utilization of Atomic Energy (USSR) \\
\hline SCEL & Small Components Evaluation Loop (HEDL) \\
\hline SCRS & Secondary Control Rond System \\
\hline SCTI & Sodium Components Test Installation (ETEC) \\
\hline SCTL & Small Components Test Loop (ETEC) \\
\hline SDD & System Design Description \\
\hline SEFOR & Southwest Experimental Fast Oxide Reactor \\
\hline SELNI & Societe Elettronucleare Italiana \\
\hline SER & Safety Evaluation Report \\
\hline SERF & Special Environment Radiometallurgy Facility (HEDL) \\
\hline SF & Support Facilities \\
\hline SG & Steam Generator \\
\hline
\end{tabular}




\begin{tabular}{|c|c|}
\hline SGR & Sodium Graphite Reactor \\
\hline SGTF & Steam Generator Test Facility (ANL-E) \\
\hline SGTR & Steam Generator Test Rig (GE) \\
\hline SHRS & Shutdown Heat Removal System \\
\hline SIG & Selenide Isotope Generator \\
\hline SIPS & Sterling Isotope Power System \\
\hline SIR & Submarine Intermediate Reactor \\
\hline SLSF & Sodium Loop Safety Facility (formerly FEFPL) (EG\&G/INEL) \\
\hline SMIS & Special Materials Information System \\
\hline SNAP & Space Nuclear Auxiliary Power \\
\hline SNL & Sandia National Laboratories \\
\hline SNM & Special Nuclear Materials \\
\hline SNR & Schnell Natriumgekuhlt Reaktor, fast sodium-cooled reactor (Germany) \\
\hline SNR & Schenectady Naval Reactors Office \\
\hline SOWAT & Small-Leak Sodium-Water Reaction Test Rig (GE) \\
\hline SPAR & Space Power Auxiliary Reactor \\
\hline SPDS & Safety Parameter Display System \\
\hline SPL & Sodium Purification Loop (HEDL) \\
\hline SPM & Solar Polar Mission \\
\hline SPTF & Sodium Pump Test Facility (ETEC) \\
\hline $\mathrm{Sr}$ & Strontium \\
\hline SR & Savannah River (South Carolina) Operations Office (DOE) \\
\hline SRDA & Sodium Removal Development Apparatus (HEDL) \\
\hline SRE & Sodium Reactor Experiment \\
\hline SRI & Stanford Research Institute \\
\hline SRL & Savannah River Laboratory \\
\hline SRP & Savannah River Plant \\
\hline SS & Stainless Steel \\
\hline S/S & Safeguards and Security \\
\hline SSCR & Spectral Shift Controlled Reactor \\
\hline SSS & Small Sodium System (HEDL) \\
\hline SSST & Site Suitability Source Term \\
\hline SSTF & Static Sodium Test Facility (ETEC) \\
\hline STCL & Source Term Control Loop (HEDL) \\
\hline STF & Safety Test Facility (now SAREF) \\
\hline STL & Sodium Tésl LuUp (GE) \\
\hline STM & Steam \\
\hline STP & Space Test Program (DOD) \\
\hline SWHC & Single Wall Helical Coil \\
\hline EWR & Sudiurn Water Reaction \\
\hline SWRI & Southwest Research Institute \\
\hline SWEATER & Sodium Friction and Wear Test Rig (WARD) \\
\hline SWU & Separative Work Units \\
\hline TBD & To Be Determined \\
\hline TCC & Technical Coordinating Committee (INFCE) \\
\hline TEC & Total Estimated Cost \\
\hline TFCT & Thorium Fuel Cycle Technology (Program) \\
\hline Th & Thorium \\
\hline $\mathrm{ThO}^{2}$ & Thuria, Thorlum Dioxide \\
\hline THORS & Thermal Hydraulic Out-of-Reactor Safety Facility \\
\hline THTR & Thorium High-Temperature Reactor \\
\hline $\mathrm{TI}$ & Texas Instruments \\
\hline Title I & Preliminary Design Phase of Project \\
\hline Title II & Final Design and Construction Phase of Project \\
\hline TMC & Technology Management Center \\
\hline TMI & Three Mile Island Reactor \\
\hline TOP & Transient Over Power \\
\hline TRA & Test Reactor Area (INEL) \\
\hline TREAT & Transient Reactor Test Facility (ANL-W/INEL) \\
\hline
\end{tabular}


TRIGA

TRU

TSF

TTF

TTL

TITF

TU

T.U. ATL

TURF

TVA

U

U-233

U-235

U-238

$\mathrm{U}^{3} \mathrm{O}^{8}$

UCLA

UC

UE\&C

UKAEA

UNC

$\mathrm{UO}^{2}$

UV

VHTR

VTRZ

W

WARD

WASH (\#)

WBS

WCA

WCB

WCBR

WCDA

WEMD

WIRE

W\%

WPAD

WSR

YAG

ZPPR
Training Reactor Isotopes, General Atomic

Transuranium

Tower Shielding Facility (ORNL)

Thermal Transient Facility (ETEC)

Transient Test Loop (HEDL)

Thermal Transient Test Facility (ORNL)

TREAT Upgrade (Part of SAREF)

TREAT Upgrade - Advanced TREAT Loop (ANL-W/INEL)

Thorium-Uranium Recycle Facility (ORNL)

Tennessee Valley Authority

Uranium

Uranium isotope with atomic weight 233

Uranium isotope with atomic weight 235

Uranium isotope with atomic weight 238

Tri-uranium oct-oxide (yellowcake)

Universily of California at Los Angeles

Uranium Dxycararhirle.

United Engineers \& Constructors, Inc.

United Kingdom Atomic Energy Authórity

United Nuclear Corp

Urania, Uranium Oxide, Uranium Diuxide (the form suitable for reactor fuel)

Ultraviolet

Very High Temperature (gas-cooled) Reactor for high-temperature process applications

Varlable Temperature Rodded Zone

Westinghouse Electric Corp.

Westinghouse Advanced Reactors Div.

The serial numbering system for reports issued by the AEC

Work Breakdown Structure

Whole-Core Accident

Water Cooled Breeder

Water Cooled Breeder Reactor

Whole Core Disrupton Accident

Westinghouse Electro-Mechanical Division

Waste Immobilization and Reactor Evaluation Program (TMI)

Weight Percent

Westinghouse Plant Apparatus Division

Waste Scrap Recycle

Yttrium Aluminum Garnet

Zero Power Plutonium Reactor (ANL-W/INEL) (now SAF) 


\section{APPENDIX D \\ Program Supporting Legislation}

The following are the major pieces of legislation that provide the authorization and mandate for the current programs of the civilian reactor development program of the Department of Energy.

\section{Atomic Energy Act of 1954, as amended (Section 31, P.L. 83-703)}

Authorizes the Department (Atomic Energy Commission in original legislation) to make arrangements for the conduct of $R \& D$ activities relating to nuclear processes, the theory and production of nuclear energy, utilization of special nuclear material, atomic energy, and radioactive material for a number of purposes, including military, medical, industrial, and commercial, and the protection of health and the promotion of safety during research and production activities.

\section{Atomic Energy Commission. Appropriation Authorization, June 2, 1970, (Section 106, P.L. 91-273)}

Authorizes the Department (ACC in original legislation) to enter into a cooperative arrangement with a reactor manufacturer and others for participation in the R\&D, design, construction, and operation of CRBR powerplant, and authorizes the Department further to conduct the Project Definition Phase.

\section{Department of Energy Organization Act, as amended (Section 309(a), P.L. 95-91)}

Transfers the Division of Naval Reactors, established by section 25 of the Atomic Energy Act of 1954, to the Assistant Secretary for Nuclear Energy.

\section{Nuclear Safety Research, Development and Demonstration Act of 1980 (P.L. 96-567)}

Authorizes the Secretary to establish a research, development, and demonstration program to carry out the purpose of the Act, which is to develop practical improvements in the generic safety of nuclear powerplants during the 5 years beginning in FY 1981. 


\section{UNITED STATES}

DEPARTMENT OF ENERGY

WASHINGTON, D.C. 20585

OFFICIAL BUSINESS

PENALTY FOR PRIVATE USE, $\$ 300$
POSTAGE AND FEES PAID

U.S. DEPARTMENT OF ENERGY DOE 350

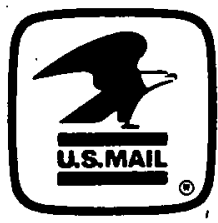

